\title{
INTEGRATED STRATIGRAPHIC CORRELATION OF UPPER DEVONIAN PLATFORM-TO-BASIN CARBONATE SEQUENCES, LENNARD SHELF, CANNING BASIN, WESTERN AUSTRALIA: ADVANCES IN CARBONATE MARGIN-TO-SLOPE SEQUENCE STRATIGRAPHY AND STACKING PATTERNS
}

\author{
TED E. PLAYTON \\ Tengizchevroil, Atyrau 060011, Kazakhstan (research conducted while at Chevron Energy Technology Company, \\ Houston, Texas, USA) \\ e-mail: tedplay@Chevron.com \\ ROGER M. HOCKING \\ Geological Survey of Western Australia, Perth WA 6004, Australia \\ ERIC TOHVER \\ University of Western Australia, Perth WA 6009, Australia \\ KELLY HILLBUN \\ University of Washington, Seattle, Washington 98195, USA \\ PETER W. HAINES \\ Geological Survey of Western Australia, Perth WA 6004, Australia \\ KATE TRINAJSTIC, BRETT ROELOFS \\ Curtin University, Perth WA 6845, Australia \\ DAVID A. KATZ \\ Whiting Petroleum, Denver, Colorado 80290, USA \\ JOSEPH L. KIRSCHVINK \\ California Institute of Technology, Pasadena, California 91125, USA \\ KLITI GRICE \\ Curtin University, Perth WA 6845, Australia \\ PAUL MONTGOMERY \\ Chevron Energy Technology Company, Houston, Texas 77002, USA \\ JEROEN HANSMA \\ University of Western Australia, Perth WA 6009, Australia \\ MAODU YAN \\ Institute for Tibetan Plateau Research, Beijing 100101, China \\ SERGEI PISAREVSKY \\ University of Western Australia, Perth WA 6009, Australia \\ SVENJA TULIPANI \\ Curtin University, Perth WA 6845, Australia
}

New Advances in Devonian Carbonates: Outcrop Analogs, Reservoirs, and Chronostratigraphy DOI: http://dx.doi.org/10.2110/sepmsp.107.10

SEPM Special Publication No. 107, Copyright (C) 2016

SEPM (Society for Sedimentary Geology), ISBN 978-56576-344-9, eISBN 978-56576-345-6, p. $248-301$. 


\title{
KEN RATCLIFFE \\ Chemostrat Ltd., Welshpool SY21 8SL, UK
}

AND

\author{
SAMUEL CAULFIELD-KERNEY, DAVID WRAY \\ University of Greenwich, Kent ME4 4TB, UK
}

\begin{abstract}
Aвstract: High-resolution, time-significant correlations are integral to meaningful stratigraphic frameworks in depositional systems but may be difficult to achieve using traditional sequence stratigraphic or biostratigraphic approaches alone, particularly in geologically complex settings. In steep, reefal carbonate margin-to-slope systems, such correlations are essential to unravel shelf-to-basin transitions, characterize strike variability, and develop predictive sequence stratigraphic models - concepts that are currently poorly understood in these heterogeneous settings. The Canning Basin Chronostratigraphy Project integrates multiple independent data sets (including biostratigraphy, magnetostratigraphy, stable isotope chemostratigraphy, and sequence stratigraphy) extracted from Upper Devonian (Frasnian and Famennian) reefal platform exposures along the Lennard Shelf, Canning Basin, Western Australia. These were used to generate a well-constrained stratigraphic framework and shelf-to-basin composite reconstruction of the carbonate system.

The resultant integrated framework allows for unprecedented analysis of carbonate margin-to-slope heterogeneity, depositional architecture, and sequence stratigraphy along the Lennard Shelf. Systems tract architecture, facies partitioning, and stacking patterns of margin to lower-slope environments were assessed for six composite-scale sequences that form part of a transgressive-to-regressive supersequence and span the FrasnianFamennian (F-F) biotic crisis. Variations are apparent in margin styles, foreslope facies proportions, dominant resedimentation processes, downslope contributing sediment factories, and vertical rock successions, related to hierarchical accommodation signals and ecological changes associated with the F-F boundary. We present these results in the form of carbonate margin-to-basin sequence stratigraphic models and associations that link seismicscale architecture to fine-scale facies heterogeneity. These models provide a predictive foundation for characterization of steep-sided flanks of reefal carbonate platform systems that is useful for both industry and academia. This study emphasizes the utility of an integrated stratigraphic approach and the insights gained from better-constrained facies and stratal architecture analysis, insights that were not achievable with traditional sequence stratigraphic or biostratigraphic techniques alone.
\end{abstract}

KEY woRDs: Canning Basin, Upper Devonian, carbonate slope, reefal margin, sequence stratigraphy

\section{INTRODUCTION}

\section{Carbonate Slope Sequence Stratigraphy}

Vertical stacking patterns used for sequence stratigraphic interpretation in carbonate platform-top settings have been well established and used for decades (e.g., Goldhammer et al. 1990, Kerans and Nance 1991, Goldhammer et al. 1993, Kerans and Fitchen 1995, Read 1995, Kerans and Tinker 1997, Tinker 1998, Lehrmann and Goldhammer 1999). Trends in high-frequency cycle thickness, facies proportions, facies offset, diagnostic indicator facies, and exposure indices can be used to interpret sequences and systems tracts from one-dimensional successions of rock (Kerans and Tinker 1997). These patterns have been calibrated to two-dimensional sequence and systems tract architecture (e.g., Kerans 1995, Tinker 1998, Osleger and Tinker 1999, Kerans and Kempter 2002). Furthermore, it has been recognized that cycle types vary along the platform-top depositional profile (e.g., Kerans 1995, Kerans and Fitchen 1995), and highfrequency facies proportions can be partitioned by systems tract (Kerans 2002).

The best-constrained carbonate margin and slope sequence stratigraphic concepts are derived from the Modern and Recent, in which depositional patterns and architectures can be linked rigorously to well-accepted proxies for eustatic sea-level changes (e.g., Droxler and Schlager 1985, Grammer and Ginsburg 1992). Seminal concepts such as "highstand shedding" (Droxler and Schlager 1985) have been developed from these data sets. However, Modern and Recent data sets come with temporal and climatic limitations (e.g., tracking single high-frequency cycles or sequences within peak icehouse conditions, respectively) that may not be applicable throughout the entire rock record. Outcrop studies, encompassing more of the rock record and diverse climatic settings with different relative sea-level behavior (e.g.,
Brown and Loucks 1993, Eberli et al. 1993, Fitchen et al. 1995, Janson et al. 2007), are also instructive. However, these data sets often lack the high-resolution constraints and physical linkages from slope to margin and/or platform-top settings required to reduce uncertainties in the sequence stratigraphic interpretation. Playton et al. (2010) provide a framework to describe carbonate margins and slopes in terms of their deposit types, margin styles, spatial architecture, and end-members, but they do not discuss sequence stratigraphic relationships in detail.

In general, the architecture of sequences and systems tracts and their internal facies stacking patterns and trends in proportions are poorly understood for carbonate margin-to-basin settings and transitions. Playton and Kerans $(2015 \mathrm{a}, 2015 \mathrm{~b})$ provide a detailed description of such relationships with Devonian examples from the Lennard Shelf and discuss the impact of long-term accommodation, ecological, and climatic controls on margin-to-slope sequence development. However, as is the case with other outcrop data sets, many stratigraphic relationships and reconstructions are inferred as the result of a lack of continuous outcrop and/or low-resolution biostratigraphic data. The sequence stratigraphic models and concepts presented here build on those of Playton and Kerans (2015a, 2015b) and document additional constraint in the stratigraphic framework developed through the Canning Basin Chronostratigraphy Project (CBCP).

\section{Canning Basin Chronostratigraphy Project}

Subsurface data sets do not typically provide the constraints necessary to correlate and characterize carbonate margin-slope-basin reservoir facies with certainty or at an adequate scale. Seismic data and biostratigraphic control are seldom at a desirable resolution, and rock data available through core have predictive limitations because 


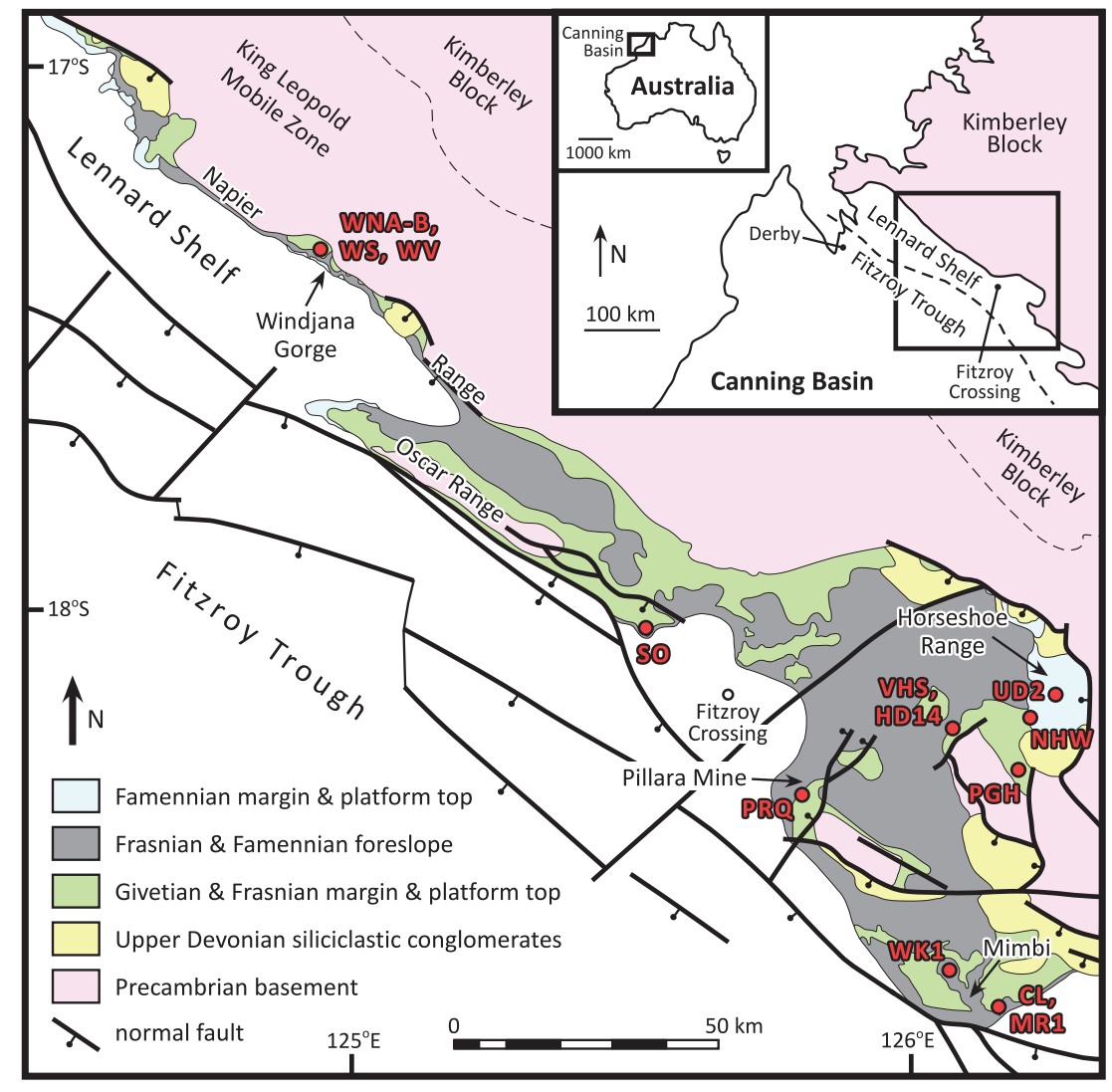

FIG. 1.-Simplified outcrop exposure and location maps of part of the Lennard Shelf, Canning Basin, Western Australia (modified after Playford et al. 2009, Frost and Kerans 2010). Red labels indicate data collection localities of the CBCP. WNA-B = Windjana North A-B measured sections; WS = Windjana Slope measured section; WV = Windjana Valley measured section; $\mathrm{SO}=$ South Oscars measured section; $\mathrm{PRQ}=$ Pillara Road Quarry measured section; VHS = Horse Spring measured section; HD14 = Horse Spring subsurface core; UD2 = Horseshoe Range subsurface core; NHW = Henwood West measured section; PGH = Guppy Hills measured section; WK1 = Wade Knoll Winkie core; $\mathrm{CL}=$ Casey Falls measured section; MR1 = McWhae Ridge Winkie core.

sequence stratigraphic rules and stacking patterns are not sufficiently developed for reef, slope, and basinal settings. There is a need for improved characterization and predictive capabilities in these settings, with significant carbonate reservoirs or plays, such as (1) Tengiz and Karachaganak Fields, Kazakhstan (e.g., Collins et al. 2006, 2013; Katz et al. 2010) involving margin-to-middle-slope productive facies; (2) Poza Rica Field, Mexico, and numerous examples in the Midland Basin, west Texas (e.g., Montgomery 1996, Janson et al. 2011, Clayton and Kerans 2013), which are conventional basin floor reservoirs; and (3) the "Wolfberry" play in the Midland Basin, west Texas (e.g., Bellian et al. 2012), which is an unconventional lowerslope to basin reservoir trend. The objective of the CBCP is to generate a well-constrained chronostratigraphic framework through integration of multiple independent data types, with a focus on carbonate shelf-to-basin correlation and sequence architecture (Playton et al. 2013). Here, we use "chronostratigraphic" to mean the identification and correlation of time-significant surfaces and timeequivalent intervals as constrained by multiple corroborating data sets. Correlations and frameworks are presented herein against stratigraphic thickness tied to well-established conodont biozones - not absolute time, as significant uncertainty remains in radiometric age dates at the high-frequency scale (i.e., biozone scale; see Kaufmann 2006).

The well-preserved Middle to Upper Devonian (Givetian, Frasnian, and Famennian) carbonate outcrops of the Lennard Shelf, northeastern
Canning Basin, Western Australia (Fig. 1), were chosen to carry out this study. This exposure belt is optimal as a result of (1) its minimal structural and diagenetic overprinting since deposition, (2) its wellexposed platform-top, reef, slope, and basinal depositional settings, and (3) a well-established preexisting geological foundation to leverage. This underpinning of previous work consists of more than five decades of research, comprehensively summarized by Playford et al. $(2009,2016)$, which provides a framework for basin development, structural setting, evolution of the reefal carbonate platforms, facies models, and numerous other characteristics of the depositional system along the Lennard Shelf. Another key advantage for the CBCP is a robust biostratigraphic framework from conodonts (e.g., Klapper 2007) cephalopods (e.g., Becker et al. 1993, Becker and House 1997), and other various vertebrates (e.g., Trinajstic and George 2009). Examples of other important work on the margins and slopes of the Lennard Shelf include that of Playford (1980, 1984), Kerans (1985), George et al. (1997), Ward (1999), Copp (2000), and Playton (2008). However, these are still limited in terms of slope sequence stratigraphic understanding and margin-to-slope architecture as a result of the inability to correlate between localities or from coeval platform-top successions. Playton and Kerans (2015a, 2015b) contributed significantly to characterization of margin and slope settings along the Lennard Shelf within the supersequence framework and ecological context surrounding the Frasnian-Famennian (F-F) 

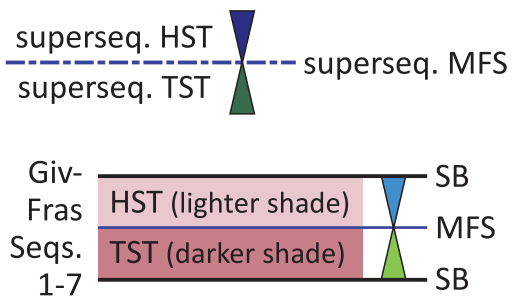

Frasnian-Famennian boundary

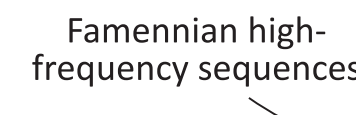

convergence of F-F \& superseq. MFS

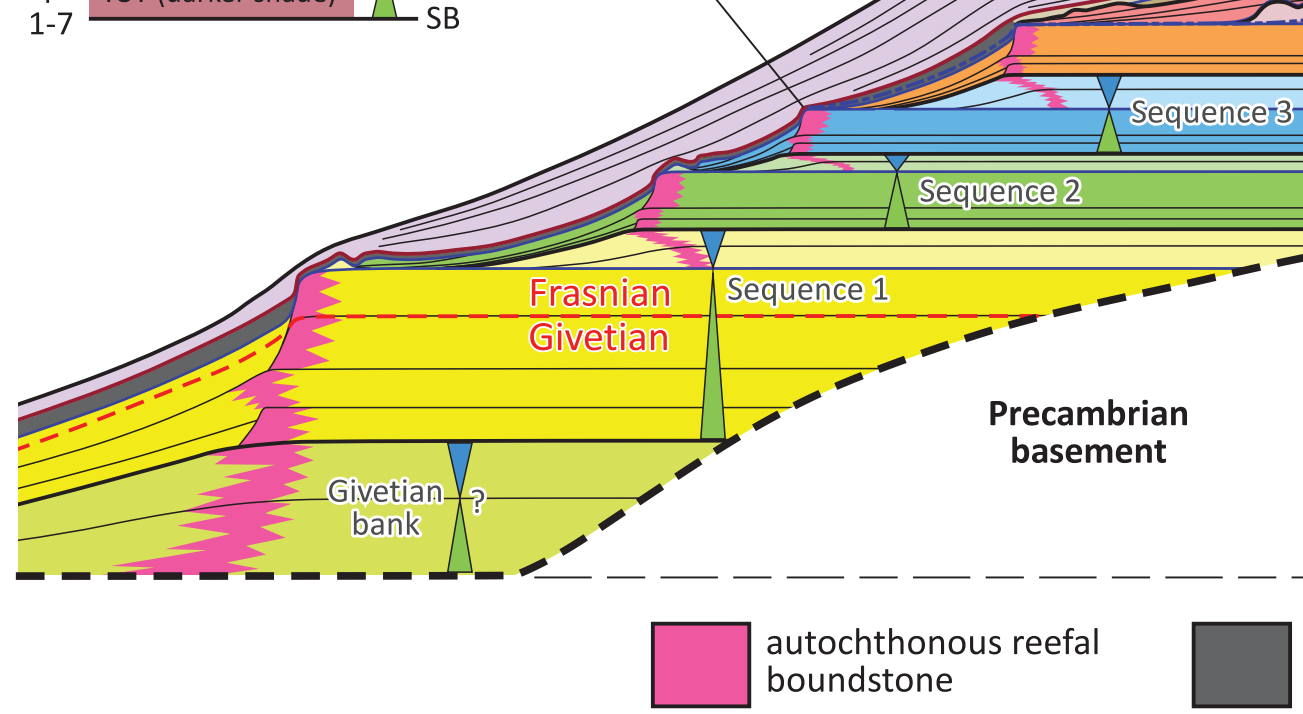

Frasnian condensed section

FIG. 2.- Idealized composite cross section and sequence architecture of the Middle-Upper Devonian carbonate system of the Lennard Shelf (modified after Playton and Kerans 2015a, 2015b). Thin black form lines denote internal stratal architecture. Individual Famennian highfrequency sequences are not shown. HST $=$ highstand systems tract; TST $=$ transgressive systems tract; MFS $=$ maximum flooding surface.

biotic crisis; however, their findings are limited by the coarse biostratigraphic resolution and lack of continuous outcrop common to all previous studies. This discontinuous nature of the Lennard Shelf outcrops and concomitant inability to "walk out" stratigraphic relationships introduces the need for using other independent constraints to link physically disconnected localities. In this sense, the correlation workflows established in this study are analogous and applicable to subsurface settings with interwell uncertainty.

Data for this study were collected (1) over 30+ Myr (Gradstein et al. 2012) of reefal platform development from the Givetian to Famennian to generate a regional stratigraphic framework for the system, (2) in platform-top, reef, slope, and basinal environments for correlation of depositional profiles, and (3) across different paleogeographic settings to demonstrate the viability of regional correlation. Hand samples and 1-inch plugs were collected and tied to detailed sedimentological logs from outcrops, and shallow Winkie cores (tripod-mounted, small-scale coring system from the surface) and deep subsurface cores were also incorporated. The samples and cores were analyzed for magnetostratigraphy (polarity reversals and magnetic susceptibility), stable isotope chemostratigraphy (inorganic carbon and oxygen), elemental chemostratigraphy, conodont-fish biostratigraphy, biomarker and compound-specific geochemistry, and natural gamma ray profiles (Playton et al. 2013). This article focuses on the integration of magnetostratigraphic, isotopic, biostratigraphic, and sequence stratigraphic constraints, as they proved most useful for regional correlation. Other integrated stratigraphic studies on carbonate systems have been carried out successfully (e.g., Montgomery et al. 2011, Davies et al. 2013) but do not rely as heavily on the specific integration of magnetostratigraphy, carbon isotope chemostratigraphy, biostratigraphy, and sequence stratigraphic concepts.

\section{Geologic Setting and Scope}

In the Middle Devonian, rifting generated deep troughs and structural highs in the eastern Canning Basin, now preserved in present-day northern Western Australia (Begg 1987, Drummond et al. 1991). The northwest-southeast-trending Fitzroy Trough developed along the northeastern margin of the Canning Basin and was fringed to the north by shallow marine settings of the Lennard Shelf, which were preferred sites for land-attached and isolated carbonate platform development. The uplifted Precambrian hinterland of the Kimberley Block confined the Lennard Shelf to the northeast and supplied fine to coarse siliciclastics to the system throughout carbonate development (e.g., Playford 1980).

The reefal carbonate system along the Lennard Shelf represents a supersequence (Fig. 2) spanning more than $25 \mathrm{Myr}$ of time (second order of Sarg et al. [1999]; after Playford et al. 2009; Playton and Kerans 2015a, 2015b; absolute age after Gradstein et al. 2012). Margins backstepped with intervening pulses of aggradation from the Givetian to Middle Frasnian, representing long-term high accommodation conditions of the supersequence transgressive systems tract (TST). Just prior to the Middle-Upper Frasnian boundary, margins shifted from long-term aggradation and backstepping to progradation, representing the supersequence maximum flooding surface (MFS). Finally, margins overall prograded from Late Frasnian to Middle 
Famennian time, representing long-term lower accommodation conditions of the supersequence highstand systems tract (HST).

Within the supersequence framework, a subordinate sequence architecture exists and is subdivided into five Givetian-Middle Frasnian backstepping and aggrading sequences (supersequence TST) and two prograding Upper Frasnian sequences (supersequence early HST; Fig. 2) (after Playford et al. 2009; Playton and Kerans 2015a, 2015b). Famennian sequences that constitute the remainder of the supersequence HST are undefined; however, high-frequency sequences have been interpreted in middle-slope settings (Playton and Kerans 2015b). The seven defined Givetian and Frasnian sequences are likely third order in duration (sensu Goldhammer et al. 1991), but because of inexact absolute age control, we will refer to them here as composite sequences with the recognition that they are components of supersequence systems tracts. We aim to use this existing supersequence and composite sequence framework for the Givetian and Frasnian and to define the Famennian sequences that constitute the remainder of the supersequence HST, with the ultimate goal of establishing a hierarchical template with which to analyze carbonate shelf-to-basin facies arrangements and architecture.

Reefal assemblages in the Givetian and Frasnian consisted of stromatoporoids and corals with variable microbial components, and platform-top settings included skeletal-peloidal pack-grainstones, bioclastic rudstones, stromatoporoid boundstone biostromes, and muddier, peloidal subtidal and intertidal facies (Playford et al. 2009). In the Famennian, reefal margins had shifted entirely into microbial assemblages (Playford 1980), and platform-tops became more oolitic (Frost 2007). Encrusted upper slope environments developed in the Late Frasnian and persisted throughout the Famennian, and detrital foreslope facies can be classified into debris-dominated, grain-dominated, and mud-dominated deposits (Playton et al. 2010, Playton and Kerans 2015b).

Given the above-mentioned dramatic change in carbonate factories, another important factor in assessing margin-to-slope sequence development is the F-F interval. The F-F event is touted as the fifth largest Phanerozoic biotic crisis and had a substantial impact on reef-building biota in particular (for background, see Playford 1980, Raup and Sepkoski 1982, Playford et al. 2009, Playton and Kerans 2015b). Characterizing the composite sequences just prior to (Upper Frasnian Sequence 7; Fig. 2) and immediately following (currently undefined) the F-F boundary will help determine the impact of lead-up and recovery phases surrounding this major extinction.

The carbonate system exposed along the Lennard Shelf provides an excellent opportunity to study carbonate margin and slope development within a combination of hierarchical accommodation and ecological controls, and the CBCP is designed to better analyze this through the addition of shelf-to-basin correlation constraints. Within the refined stratigraphic framework, we focus on margin-to-basin sequence architecture, margin styles, slope stacking patterns, and margin-to-slope facies heterogeneity. These margin-to-basin characteristics are described in terms of large-scale patterns, such as debris-, grain-, and mud-dominated slopes, and escarpment vs. accretionary margins (after Playton et al. 2010). Given this data set and our objectives, we present herein:

(1) Lennard Shelf regional correlation framework and stratigraphic reference chart for the Late Devonian based on an integrated approach;

(2) a well-constrained shelf-to-basin reconstruction of the Lennard Shelf, highlighting margin and slope development and sequence stratigraphic expression; and

(3) an examination of carbonate slope sequences, systems tracts, and stacking patterns, with the aim of generating conceptual models and predictive relationships.

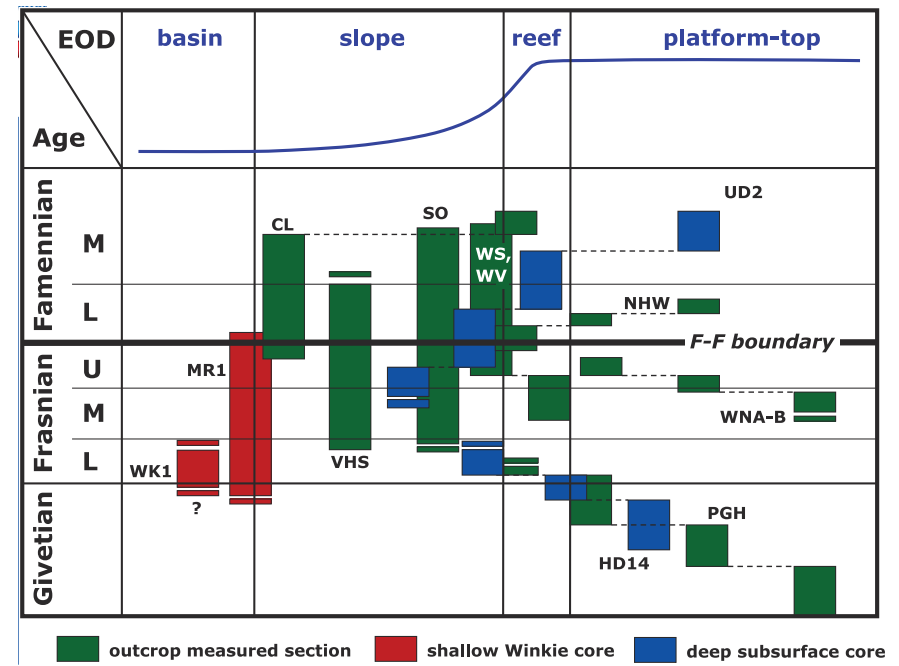

FIG. 3.-Diagram showing CBCP sampling coverage in terms of age (y-axis), depositional environment (x-axis), and sample transect type (colors). F-F boundary $=$ Frasnian-Famennian extinction boundary; U, M, and L indicate Upper, Middle, and Lower subdivisions of Stages, respectively, and are arbitrarily spaced. Single sections or cores can record multiple environments over time, as indicated by connecting dashed lines. WNA, WNB, WS, and WV sections and CL-MR1 transects, respectively, were physically linked through walkouts-all other stratigraphic correlations were achieved through agreement of multiple data profiles. Refer to Figure 1 for distances between localities along the Lennard Shelf.

\section{DATA SET AND METHODOLOGY}

\section{Stratigraphic Transects and Sampling}

The CBCP field data collection goal was to achieve detailed measuring and high-density sample coverage for shelf-to-basin carbonate environments (inner and outer platform-top, reef, slope, and basin) across the Middle-Late Devonian stages (Givetian, Frasnian, Famennian) exposed along the Lennard Shelf. Key outcrop transects (measured sections) with an appropriate degree of stratigraphic overlap were chosen to fulfill these coverage requirements, and shallow Winkie cores or subsurface cores were incorporated to fill in gaps in outcrop measured section availability (Fig. 3). Samples collected were tied to detailed stratigraphic logs, including oriented outcrop plugs and hand samples (required for paleomagnetics), unoriented hand samples, and large slabs to document complex depositional fabrics. Shallow Winkie drilling provided oriented cores up to $40 \mathrm{~m}$ from the surface, while subsurface cores made available up to $700 \mathrm{~m}$ of unoriented stratigraphy. In total, nearly 6800 samples were collected, and 4000 $\mathrm{m}$ of stratigraphy were measured and described from 17 measured sections and cores along a $200-\mathrm{km}$ transect with 10 to $100-\mathrm{km}$ spacing (Table 1). Across the data set, the average vertical sample spacing was $59 \mathrm{~cm}$, with a range from 16 to $95 \mathrm{~cm}$, and depositional environment and sedimentation rate were accounted for during collection to avoid data resolution biases; settings with interpreted low sedimentation rates (i.e., distal slope or basinal environments) were sampled at higher frequencies than were those with high sedimentation rates (i.e., middle-slope grain-dominated 


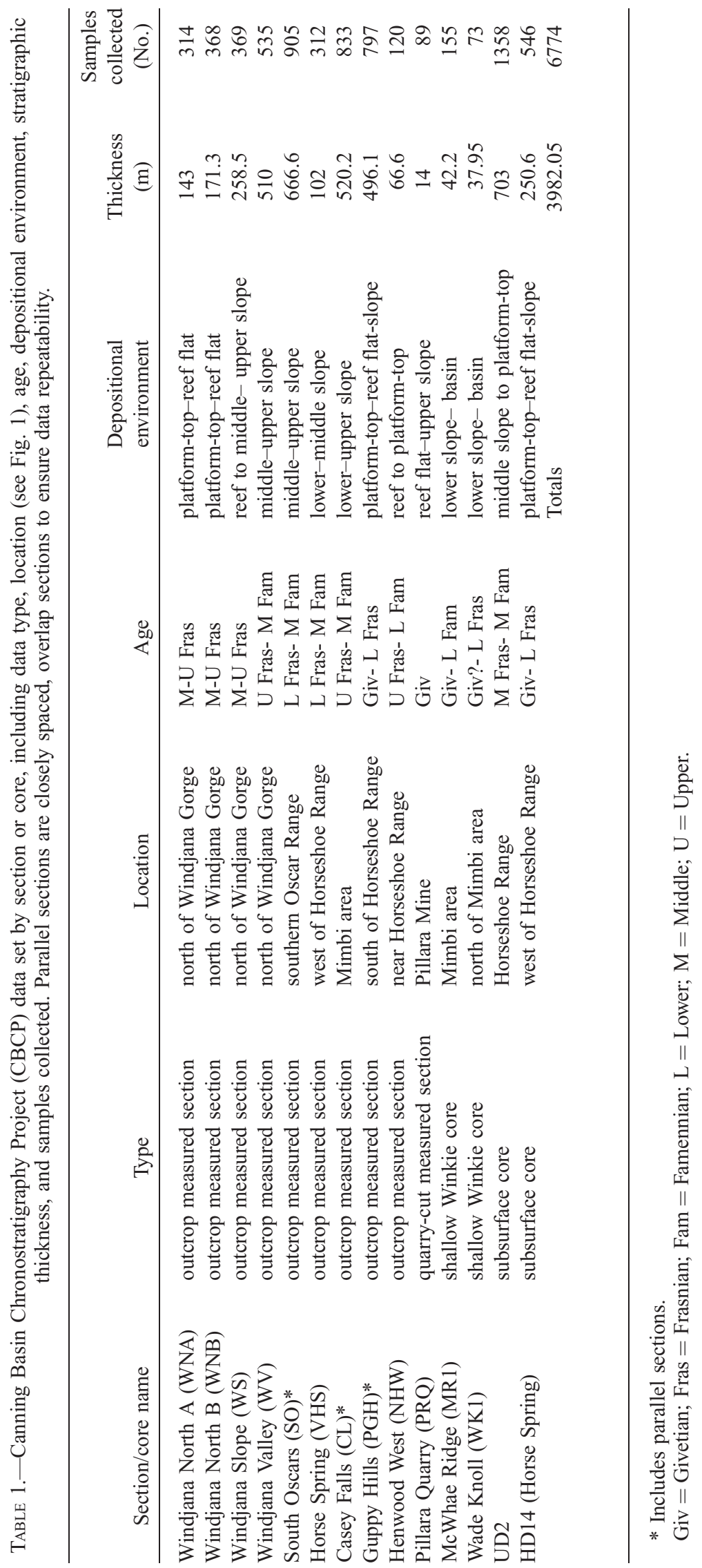


or debris-dominated environments). Additionally, the matrix within debris deposits was targeted for collection, while allochthonous blocks of resedimented, previously lithified material were avoided, to minimize measurement ambiguity in detrital slope facies. To ensure the desired sample coverage, key platform-top, margin, slope, and basin outcrop localities around the Lennard Shelf exposure belt were prioritized based on extent, exposure, preservation, and accessibility (Fig. 4). Detailed facies schemes were developed to describe the dominant rock types, settings, and processes along Givetian, Frasnian, and Famennian depositional profiles (Table 2; Fig. 5). Appendices 1 through 14 contain the detailed sedimentary log, conodont control, stable carbon isotopic profile, paleomagnetic reversals, and interpreted sequence stratigraphy for each measured section and core and provide summaries of location (Fig. 1), paleogeography, age, facies assemblages, depositional environment(s), vertical succession, and lithology. Section names and mnemonics are informal terms as used in the field for ready reference to data transects.

\section{Correlation Constraints}

The refined regional stratigraphic framework presented here builds on the work of Playford et al. (2009) and Playton and Kerans (2015a, $2015 b$ ) and uses conodont biostratigraphy, paleomagnetic reversals, and stable carbon isotopes as the principal correlation constraints. These data all have global significance, and their primary signals were well preserved in enough instances to use with confidence. Elemental suites, magnetic susceptibility, outcrop gamma ray, biomarkers, and compound specific isotopes were less useful for regional stratigraphy as a result of commonly intermixed siliciclastics and uncommon organic-rich rocks and thus are not discussed here. Absolute dating via $\mathrm{U}-\mathrm{Pb}$ geochronology was attempted on samples with little visible alteration that were selected from both platform-top sections (Windjana North A Section [WNA] and Windjana North B Section [WNB]; Appendices 2, 3) and the purest carbonate section (South Oscars Section [SO]; Appendix 6); however, results were erroneous or lacked the necessary precision, again as a result of the intermixing of siliciclastics inherent to the Lennard Shelf. The following sections summarize the key correlation constraints, including previous studies, CBCP contributions (Table 3), general methodology, and limitations.

Conodont Biostratigraphy: Middle-Late Devonian biozones, largely defined from conodonts and cephalopods, are well established globally from work in Europe, the Lennard Shelf, and other localities (Klapper 1989, 1997, 2007; Ziegler and Sandberg 1990; Becker et al. 1993; Girard et al. 2005; Trianjstic and George 2009). This enormous collection of past work around the world provides a high-quality foundation for the other data sets collected, such as paleomagnetic reversals and stable carbon isotopes. Although leveraging from previous work was critical, the CBCP rigorously collected additional conodonts (and to a lesser extent, fish) at each locality, tying into, infilling, and/or extending data sets from published accounts or generating new biostratigraphic profiles in undocumented localities (Roelofs et al. 2015). Despite the robustness of conodont biostratigraphy, a fundamental limitation is the virtual absence of age-diagnostic species in shallower reefal margin or platform-top settings; the shortranging organisms useful for constraint preferred deeper slope and basinal settings. In addition to this restriction, certain paleogeographic settings appear to favor conodont abundance over others, as slope localities with associated narrow shelves and abundant siliciclastic influx are known for low yields of useable conodont remains. Thus, three measured sections served as the "reference conodont profiles" for the CBCP data set (SO, Virgin Hills South [VHS], and Casey Falls [CL] sections; Appendices 6-8), which were closely tied to the global references and provided biostratigraphic context to other constraints that could be cross-correlated to transects with lesser biostratigraphic control.

The two most significant global extinction events in the data set, the Givetian-Frasnian (G-F) and F-F extinctions, were key biostratigraphic markers. The G-F faunal turnover is substantial in terms of biodiversity, like the F-F, but it is less understood and documented. The F-F boundary in the $\mathrm{CBCP}$ data set is constrained to an interval that is less than $5.5 \mathrm{~m}$ thick in the SO, VHS, and CL measured sections (Appendices 6-8) and has previously been resolved with centimeter precision solely from conodonts (Klapper 2007). The G-F boundary, of lesser importance to this study than the F-F boundary, has virtually no biostratigraphic control but is picked in the lower few meters of the McWhae Ridge Winkie core (MR1; Appendix 11) based on a distinctive biomarker character (Tulipani et al. 2014, 2015), and in the Guppy Hills measured section (PGH; Appendix 9) based on very poorly constrained vertical successions in coral morphology and assemblage.

Paleomagnetic Polarity Reversals: A somewhat unique strength of paleomagnetic polarity in terms of chronostratigraphic utility is that it is a truly global phenomenon that is independent of environment and setting. For much of the Phanerozoic geologic timescale, paleomagnetic polarity reversals are well defined and can be used as a global reference; however, the Middle to Late Devonian global reversal record has to date been poorly defined (Gradstein et al. 2012). Thus, for the purposes of the CBCP, there was no available reference to reproduce, and consequently the Middle-Late Devonian paleomagnetic polarity record had to be generated via this data set in order to achieve project success (Hansma et al. 2015). To accomplish this, chrons or chron packages (intervals of dominant or distinctive mixed polarity) were identified that could be correlated across the data set within tightly constrained conodont control, with the limitation that biostratigraphic constraint was partial, confined to slope and basin transects. However, many of the key transects of the $\mathrm{CBCP}$ are in slope and basin positions, and these were sufficient to establish a composite reversal stratigraphy across the data set. The episodic nature of resedimentation in these settings did not introduce significant uncertainty or noise in the correlations, as indicated by excellent repeatability around the data set within conodont control. Hansma et al. (2015) describes in detail the intensive process carried out to ensure extraction of primary paleomagnetic signals.

Twenty-seven Givetian to Middle Famennian chrons or chron packages were established (modified after Hansma et al. 2015) that are tied to the conodont zones, adding a significant amount of granularity to the Devonian global paleomagnetic record and providing numerous additional correlation pinning points across the Lennard Shelf (Fig. 6). Mixed polarity zones were encountered-meaning reversal rate was frequent but with a dominant interval polarity - and their bounds were correlated with confidence. However, their internal complexity was not always well reproduced across the data set.

Stable Carbon Isotopes: Unlike the Middle to Upper Devonian paleomagnetic global reference record prior to the CBCP, wellaccepted and constrained secular stable inorganic carbon isotope curves have been assembled from data sets across the world (e.g., Joachimski et al. 2002, Bing et al. 2003, Buggisch and Joachimski 2006) and are available for correlation purposes. These reference curves exhibit well-expressed isotopic excursions that are closely tied to conodont biozones, occurrences of anoxic facies, and biotic events; this combination makes Devonian carbon isotopes excellent candidates for chronostratigraphic constraints. Canning Basin Chronostratigraphy Project sampling relied heavily on slope and basin transects with the most conodont control to resolve these Middle-Upper Devonian carbon excursions. Carbon isotope signatures were well 

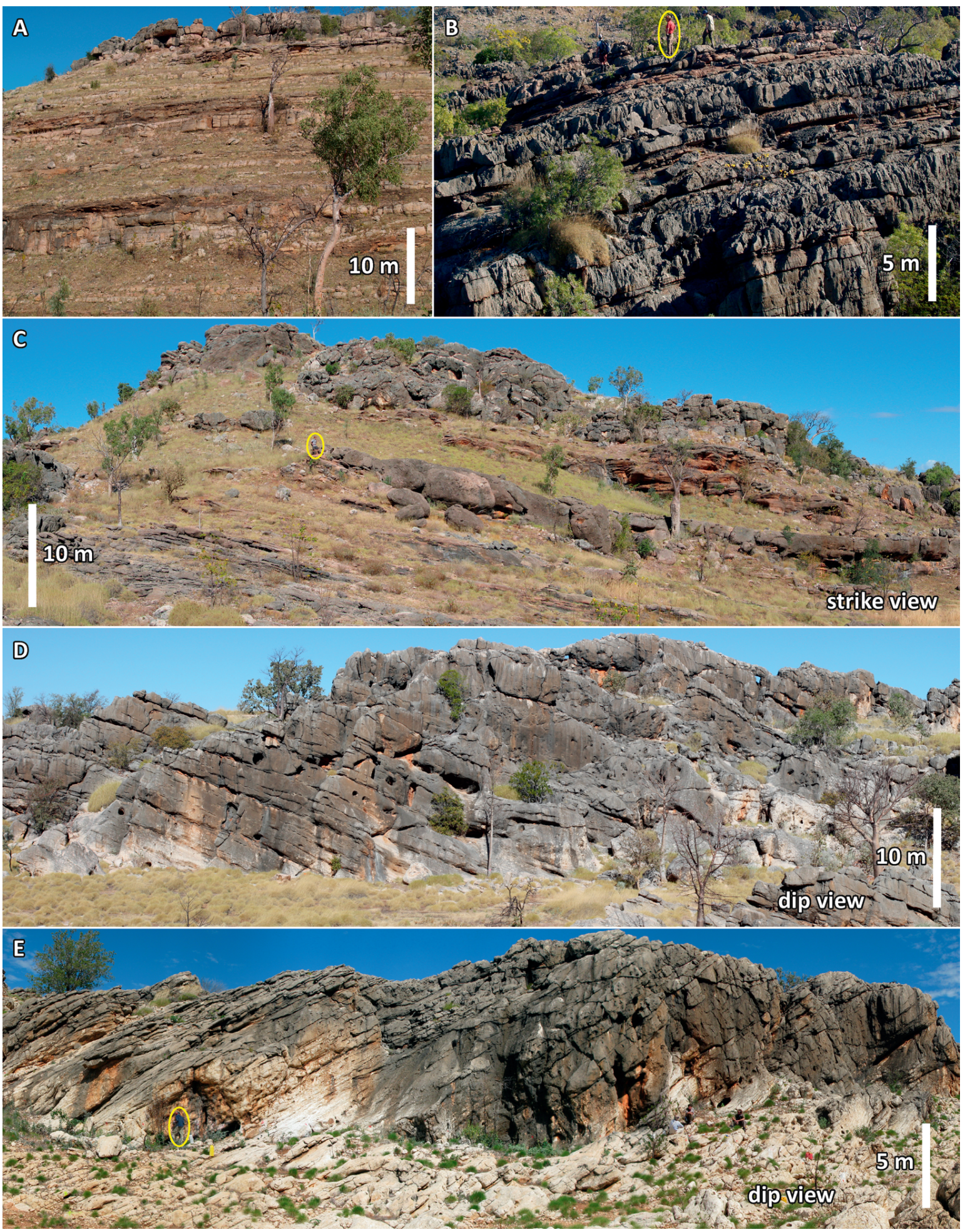

FIg. 4.-Examples of CBCP outcrop localities (after Playton et al. 2013). A) Frasnian inner platform cycles of the Windjana North B Section (WNB). B) Frasnian reef-flat cycles of the Windjana North A Section (WNA). C) Frasnian middle- to upper-slope strata of the Windjana Slope Section (WS). D) Frasnian middle-slope strata of the South Oscars Section (SO). E) Famennian upper-slope strata of the Casey Falls Section (CL). Yellow circles indicate people for scale. See Figure 1 for locations along the Lennard Shelf. 
TABLE 2.-Facies scheme used for the CBCP. EOD = environment of deposition. See Appendix 1 for color scheme used in measured sections.

\begin{tabular}{|c|c|c|}
\hline Major EOD & Rock description & Setting \\
\hline \multirow[t]{13}{*}{ Shelf-shoreline } & $\begin{array}{l}\text { rugose coral-encrusting stromatoporoid boundstone- } \\
\text { floatstone w/ organic-rich matrix }\end{array}$ & in situ Givetian transgressive shelf \\
\hline & $\begin{array}{l}\text { organic-rich argillaceous mudstone-wackestone } \pm \text { open } \\
\text { marine skeletals }\end{array}$ & Givetian transgressive shelf \\
\hline & skeletal-lithiotid boundstone-floatstone & \pm in situ Famennian outer platform-top \\
\hline & peloid-skeletal oncolitic floatstone-rudstone & outer platform-top (common in Famennian) \\
\hline & skeletal-peloid packstone-grainstone & outer platform-top \\
\hline & bioclastic floatstone-rudstone & outer platform-top \\
\hline & nonskeletal-dominated packstone-grainstone & platform-top crest (common in Famennian) \\
\hline & teepee-pisolite complex & Famennian platform-top crest \\
\hline & burrowed peloidal wackestone-packstone; \pm skeletals & inner platform-top \\
\hline & $\begin{array}{l}\text { fenestral peloidal mudstone-wackestone; } \pm \\
\text { stromatolitic laminations }\end{array}$ & inner platform-top \\
\hline & massive-laminated siliciclastic siltstone & siliciclastic-dominated shallow marine shelf \\
\hline & massive-stratified siliciclastic sandstone & siliciclastic-dominated shallow marine shelf \\
\hline & siliciclastic conglomerate & siliciclastic-dominated shoreline-fluvial plain \\
\hline \multirow[t]{7}{*}{ In situ margin-slope } & stromatolitic-stromatactoid microbial boundstone & in situ slope bioherms-biostromes \\
\hline & $\begin{array}{l}\text { stromatactoid skeletal-microbial boundstone } \\
\text { encrusted-microbially stabilized skeletal-peloid-coated } \\
\text { grain packstone-grainstone }\end{array}$ & $\begin{array}{l}\text { in situ encrusted upper slope-deeper margin } \\
\text { encrusted upper slope-deeper margin }\end{array}$ \\
\hline & $\begin{array}{l}\text { fenestral-massive Renalcis-dominated microbial } \\
\text { boundstone }\end{array}$ & in situ Famennian reef \\
\hline & $\begin{array}{l}\text { fenestral-stromatactoid microbial-Renalcis- } \\
\text { Actinostroma boundstone }\end{array}$ & in situ Frasnian reef \\
\hline & $\begin{array}{l}\text { well-bedded stromatolitic-stromatactoid microbial } \\
\text { boundstone }\end{array}$ & in situ Famennian reef flat \\
\hline & $\begin{array}{l}\text { well-bedded Stachyodes-Actinostroma boundstone; } \\
\text { variable encrustation }\end{array}$ & in situ Givetian-Frasnian reef flat \\
\hline & Amphipora-Stachyodes boundstone-floatstone & $\begin{array}{l} \pm \text { in situ Givetian-Frasnian reef flat-outer } \\
\text { platform-top }\end{array}$ \\
\hline \multirow[t]{9}{*}{ Transported slope--basin } & $\begin{array}{l}\text { reefal margin-slope-derived megabreccia- } \\
\text { allochthonous block(s) }\end{array}$ & resedimented slope \\
\hline & $\begin{array}{l}\text { platform-margin-slope-derived bioclastic rudstone-- } \\
\text { breccia }\end{array}$ & resedimented slope (rare in basin) \\
\hline & slope-derived intraclastic rudstone-breccia & resedimented slope (rare in basin) \\
\hline & platform-derived skeletal-peloid packstone-grainstone & resedimented slope (rare in basin) \\
\hline & $\begin{array}{l}\text { platform-derived nonskeletal-dominated packstone-- } \\
\text { grainstone }\end{array}$ & resedimented slope (rare in basin) \\
\hline & fine-medium calcareous sandstone & resedimented slope \\
\hline & $\begin{array}{l}\text { platform-margin-slope-derived silty skeletal-peloid } \\
\text { wackestone-packstone }\end{array}$ & resedimented slope-basin \\
\hline & $\begin{array}{l}\text { margin-slope-derived silty peloidal wackestone- } \\
\text { packstone } \pm \text { wisps-laminations }\end{array}$ & resedimented slope-basin \\
\hline & $\begin{array}{l}\text { margin-slope-derived silty (micro)peloidal mudstone- } \\
\text { wackestone } \pm \text { wisps-laminations }\end{array}$ & resedimented slope-basin \\
\hline Other & crystalline rock & basement \\
\hline
\end{tabular}

reproduced across the data set, despite the potential for discontinuous foreslope deposition.

In order to extract global isotopic excursions from the Lennard Shelf rocks, primary signals representing the Devonian ocean inorganic carbon pool must be collected, as overprints like meteoric or burial diagenesis and siliciclastic contamination can compromise the native marine signal. Thus, a rigorous quality control process was developed that handles extremely large data sets (thousands of samples) while effectively filtering out diagenetically altered samples (Hillbun 2015). This procedure results in high-confidence interpretations of isotopic profiles believed to represent the primary marine inorganic carbon character of the Devonian oceans. A limitation 


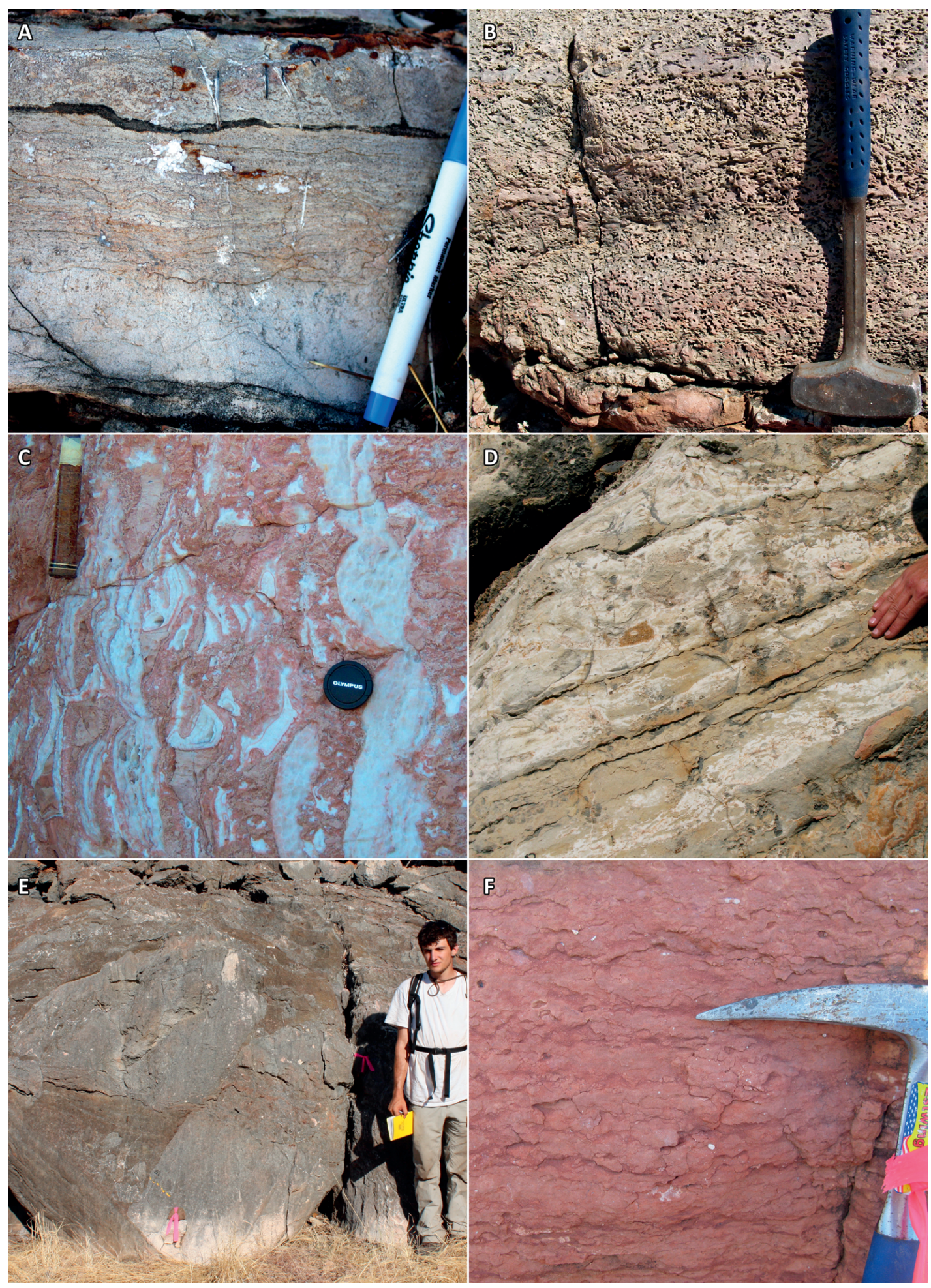

FIG. 5.- Outcrop photo examples of facies documented for the CBCP. A) Crinkly laminated fenestral peloidal wackestone, Givetian inner platform-top, Guppy Hills Section (GHB). B) Moldic Amphipora stromatoporoid rudstone, Frasnian outer platform-top, Windjana North A Section (WNA). C) Horizontally accreting Actinostroma stromatoporoid framestone, Frasnian reef core, Henwood West Section (NHW). Basinward is to the left. D) Steeply dipping stromatactoid microbial boundstone, Famennian upper slope, Casey Falls Section (CL). E) Megabreccia with meter-scale boulders and quartz-rich matrix, Famennian middle slope, Windjana Valley Section (WV). F) Mottled silty peloidal wackestone, Famennian toe of slope, Casey Falls Section (CL). See Figure 1 for locations along the Lennard Shelf. 
TABLE 3.-Foundational work and $\mathrm{CBCP}$ studies pertaining to the primary constraints used for regional correlation.

\begin{tabular}{lll}
\hline \multicolumn{1}{c}{ Constraint } & \multicolumn{1}{c}{ Previous work } & \multicolumn{1}{c}{ This study } \\
\hline Sequence stratigraphy & Playford et al. (2009); Playton and Kerans & this paper \\
& (2015a, 2015b) & \\
Conodont, cephalopod, and & Klapper (1989); Ziegler and Sandberg & Roelofs et al. (2015) \\
fish biostratigraphy & $(1990) ;$ Becker et al. (1993); Klapper & \\
& $(1997) ;$ Becker and House (1997); Girard & \\
& et al. (2005); Klapper (2007); Trinajstic & \\
and George (2009) & Hansma et al. (2015) \\
Magnetostratigraphy & none pertaining to regional correlation & Hillbun (2015); Hillbun et al. (2015, 2016) \\
$\begin{array}{l}\text { Stable carbon isotope } \\
\text { chemostratigraphy }\end{array}$ & Joachimski et al. (2002); Bing et al. (2003); & \\
& Stephens and Sumner (2003); Buggisch & \\
& and Joachimski (2006) & \\
\hline
\end{tabular}

encountered occurred in platform-top settings, in which pervasive meteoric diagenesis and siliciclastic contamination effectively polluted any remnant of the Devonian oceanic isotopic expression, thereby rendering stable carbon isotopes ineffective for chronostratigraphy (Hillbun 2015). Stable inorganic oxygen isotopes were incorporated into the quality control workflow as an indicator of certain styles of diagenesis.

Eleven stable inorganic carbon isotope excursions were identified and nine were correlated, within conodont control, across the data set in the slope and basinal transects, providing an excellent suite of independent correlation constraints (Fig. 6) (after Hillbun 2015, Hillbun et al. 2015). Four of the excursions are documented global events from previous studies (falsiovalis, Lower and Upper Kellwasser, and Enkeberg events, after Buggisch and Joachimski 2006), two of which were identified in only one transect and were therefore not reproducible across the data set. The remaining seven were correlatable around the CBCP data set but were not defined consistently in other studies, either elsewhere around the world or along the Lennard Shelf.

\section{Lennard Shelf Regional Stratigraphy and Reconstruction}

To construct a regional framework, we honored multiple independent signals embedded in the rock record in conjunction with sequence stratigraphic concepts to interpret and correlate timesignificant surfaces across the Lenard Shelf. The end product, a predictive sequence stratigraphic framework, abides by all constraints but is ultimately governed by the sedimentology of the rocks and the observed stratigraphic relationships. As a result of the nature of the Lennard Shelf outcrop belt (Fig. 1), transect localities are physically disconnected over great distances (i.e., walkout ties were impossible across major localities) and correlation solutions are non-unique-a challenge also inherent in subsurface data sets. However, the agreement of multiple independent data types greatly reduces the range of possibilities and uncertainty in making correlation decisions.

Degree of Confidence and Limitations: As is the case with every data set, the CBCP data set has gaps, limitations, and uncertainties because of which assumptions and less-constrained interpretations are required. In particular, the $\mathrm{CBCP}$ data set works with globally recognized events and intervals that impart a high degree of confidence but also utilizes lower-confidence regional signals and assumed global signals that were not previously defined (Table 4). The globally defined conodont biozones and Lower and Upper Kellwasser isotope excursions are the highest confidence anchors of the regional framework (Table 3). However, regional isotope excursions (those that correlate across the Lennard Shelf but are not recognized globally) and the polarity reversal record also serve as an important set of pinning points for correlation; although not global, their repeatability across the data set lends credibility to their use as chronostratigraphic constraints. The CBCP polarity reversal record is a special case in that a global reference for this time period was previously undefined, and this larger study establishes it for the first time (Hansma et al. 2015). Accordingly, the transects of the CBCP had a range of utility (Table 4), some with very little control (e.g., PGH, Horseshoe Range subsurface core [UD2], Horse Spring subsurface core [HD14]; Appendices 9, 13, 14), but still proved useful in the final reconstruction, and some served as cornerstones (reference transects) for the framework to which the other transects are tied (WNA, WNB, SO, VHS, CL, MR1; Appendices 2, 3, 6, 7, 8, 11).

Three key interlinked limitations, some of which are unique to the CBCP, presented challenges with respect to shelf-to-basin correlation: (1) extraction of conodont data for biostratigraphy; (2) preservation of primary carbon isotope signals; and (3) stacking pattern criteria for sequence stratigraphic interpretation. Platform-top settings were practically devoid of any useful conodont or isotopic information for correlation. Despite these limitations, the platform-top transects exhibited clean reversal records and, importantly, contained stacking pattern information that was valuable for sequence stratigraphic interpretation. One-dimensional stacking pattern analysis, utilizing criteria such as facies proportions, facies offset, cycle thickness, indicator facies, and exposure indicators (sensu Kerans and Tinker 1997), was performed in platform-top transects to identify systems tracts, sequence boundaries, and MFSs. Presence and thickness of stromatoporoid bioherms and laminated or fenestral tidal flats proved to be a critical indicator facies for stacking pattern analysis, and the proportion of open marine vs. restricted rock types was a key parameter with which to define cycles and systems tracts. The proportions of shallow marine siliciclastics were less useful, however, because of their highly localized nature, inconsistency relative to carbonate shallowing or deepening trends, and seemingly sporadic influx across the narrow carbonate shelf. Unlike these tools available for platform-top sequence interpretation, the CBCP slope transects, consisting of resedimented material and microbially encrusted deposits, exhibit successions that are poorly understood with respect to sequence stratigraphy; the advantage of the slope transects are the pristinely preserved carbon isotope records and abundant biostratigraphic control. Integrating the $\mathrm{CBCP}$ data set therefore required consolidation of multiple signals, each with differing degrees of confidence and utility, based upon the section type and/or setting being interpreted. Differences in information preservation and quality among the variable environments are common for any data set and 


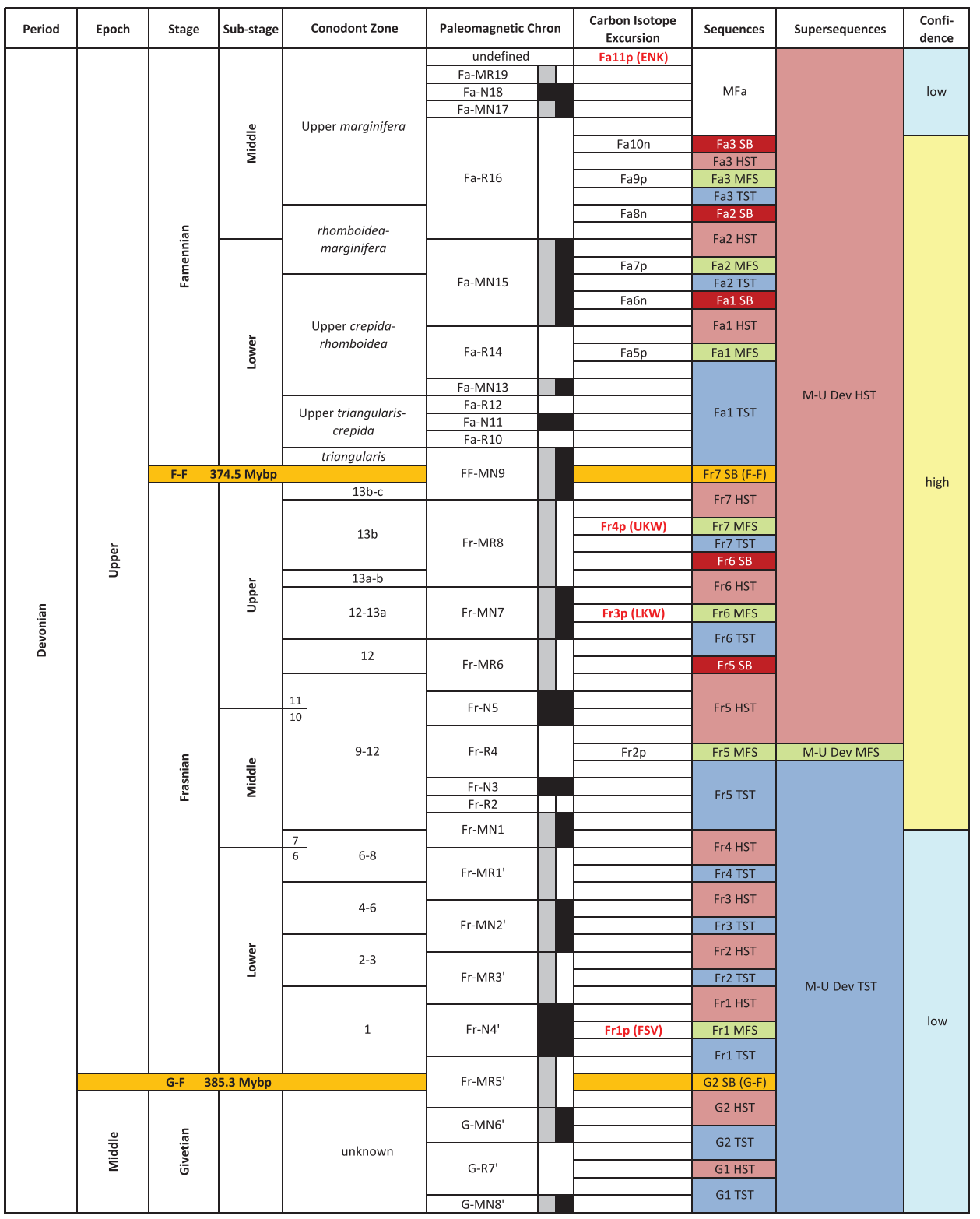

FIG. 6.-Middle-Upper Devonian (Givetian, Frasnian, and Famennian) chronostratigraphic chart developed from the CBCP, showing geologic subdivisions, conodont biozones, paleomagnetic polarity chrons, stable carbon excursions, and sequence stratigraphic framework. Absolute ages from Gradstein et al. (2012). In Low Confidence Lower Frasnian, conodont zones relative to sequences adapted from Playford et al. (2009). Light gray subcolumns (left) in "Paleomagnetic Chron" indicate mixed polarity zones with dominant interval polarity on right. Global carbon isotope excursions identified in red (after Buggisch and Joachimski 2006). FSV = falsiovalis excursion; LKW $=$ Lower Kellwasser excursion; UKW = Upper Kellwasser excursion; ENK = Enkeberg excursion.

underscore the power of integrating multiple constraints to develop a regional framework.

Platform-to-Slope Correlation and Slope Sequence Stratigraphy: Considering the above, the following limitations posed a challenge when correlating platform sections to slope sections: (1) without biostratigraphic control in the platform-top, it was unclear how to correlate reversals into the slope, and (2) picking sequence stratigraphic surfaces and systems tracts in the slope was difficult as slope stacking patterns are not well established. To overcome this, beds were physically traced from the platform-top sections (WNA and WNB sections; Appendices 2, 3) into a key nearby outcrop exposure, the Classic Face in Windjana Gorge (Fig. 7). The Classic Face is a world-class locality for observing carbonate platform-to-slope transitions across the long-term shift from margin aggradation to progradation (see Playford et al. 2009, Playton and Kerans 2015a). There are key geometries in the Classic Face that allow confident placement into the supersequence architecture (Fig. 2), as well as 
TABLE 4.-Confidence levels for CBCP measured sections and cores (a) and markers or intervals used for chronostratigraphy (b). Green = highest confidence. Yellow = medium-high confidence. Red = low confidence. See Table 1 for measured section abbreviations. "Regional constraints" are those correlated across the CBCP data set but not linked to global references. LKW $=$ Lower Kellwasser; UKW $=$ Upper Kellwasser; FSV = falsiovalis; ENK = Enkeberg.

\begin{tabular}{|c|c|}
\hline \multicolumn{2}{|c|}{ a) Sections } \\
\hline WNA & some independent global to regional constraints \\
\hline WNB & some independent global to regional constraints \\
\hline WS & some independent global to regional constraints \\
\hline WV & some independent global to regional constraints \\
\hline SO & numerous independent global to regional constraints \\
\hline VHS & numerous independent global to regional constraints \\
\hline CL & numerous independent global to regional constraints \\
\hline PGH & few-none independent global to regional constraints \\
\hline NHW & few-none independent global to regional constraints \\
\hline MR1 & numerous independent global to regional constraints \\
\hline WK1 & few-none independent global to regional constraints \\
\hline UD2 & few-none independent global to regional constraints \\
\hline HD14 & few-none independent global to regional constraints \\
\hline
\end{tabular}

\begin{tabular}{|c|c|}
\hline \multicolumn{2}{|c|}{ b) Markers and Intervals } \\
\hline all magnetic polarity reversals & correlatable across dataset; not linked to global reference \\
\hline all biostratigraphic picks & correlatable across dataset; linked to global reference \\
\hline LKW \& UKW carbon excursions & correlatable across dataset; linked to global reference \\
\hline FSV \& ENK carbon excursions & isolated occurrences; linked to global reference \\
\hline all other carbon excursions & correlatable across dataset; not linked to global reference \\
\hline elemental trends & not correlatable across dataset; no global reference \\
\hline magnetic susceptibility trends & not correlatable across dataset; no global reference \\
\hline outcrop gamma ray trends & not correlatable across dataset; no global reference \\
\hline biomarker trends & not correlatable across dataset; no global reference \\
\hline
\end{tabular}

some surrounding biostratigraphic pinning points. This linkage to the sequence succession defined at the Classic Face allowed for extrapolation of coarse age information to the otherwise temporally unconstrained platform-top transects. These coarse constraints were sufficient to correlate reversals from platform-top to slope sections, thereby linking more robust age control into the shallower settings and extending sequence stratigraphic interpretations into the slope. In slope intervals with no platform-top equivalents within the data set, the F-F boundary, identified by conodonts, was also a key marker from which to hinge sequence stratigraphic interpretations, as it is a significant sequence boundary (Playford et al. 2009). Additionally, the Kellwasser events are interpreted to be coincident with MFSs in multiple studies (e.g., Buggisch and Joachimski 2006) providing further sequence stratigraphic context to the slope.

The application of platform-constrained sequence stratigraphic interpretations, and other pinning points, to the slope allowed for examination of slope stacking patterns, systems tracts, and sequence development. In doing so, an empirical relationship was extracted that links carbon isotopic trends to slope sequence stratigraphy (Hillbun et al. 2016). A commonly observed pattern was carbon isotope values trending positive during Frasnian sequence TSTs and negative during HSTs. Maximum flooding surfaces tended to be associated with carbon isotope value maxima and sequence boundaries (SBs) with carbon isotope value minima. The model to explain this linkage between the oceanic carbon pool and sequence stratigraphy along the Lennard Shelf is discussed in Hillbun et al. (2016) and entails changes in circulation patterns during TST vs. HST settings (after Katz et al. 2007). This relationship was independently observed enough times that a proxy was developed for a slope sequence stratigraphic interpretation method that utilizes carbon isotope trends when stratigraphic overlap to platform-top equivalents was not possible. This provides another valuable tool for generating the sequence stratigraphic framework and extrapolating platform-top-defined sequences to multiple slope sections across the data set.

Development of the Lennard Shelf Framework and Reconstruction: Employing the above methods, an integrated stratigraphy was generated that links all time-significant markers and intervals with a conforming sequence stratigraphic framework for the Middle-Late Devonian of the Lennard Shelf (Fig. 8). The workflow used to incorporate components and arrive at a final stratigraphic framework is as follows:

(1) Define the underpinning biostratigraphic constraints in slope and basin transects;

(2) Within biostratigraphic control, identify and correlate global isotope excursions in slope and basin transects;

(3) Within biostratigraphic and global isotopic control, correlate through-going polarity reversal packages across slope and basin transects;

(4) Utilize sparse age information extrapolated from nearby key outcrops (Classic Face, Windjana Gorge; Fig. 7) and correlate platform-top reversals to slope and basin reversals;

(5) Within biostratigraphic, isotopic, and established polarity reversal control, identify and correlate regional isotope excursions in slope and basin transects; and

(6) Interpret a conforming sequence stratigraphic framework based on sedimentology that honors all established constraints, considers the various degrees of confidence around the data set, and utilizes the proxies developed that link isotopic expression in the slope with systems tracts.

This process involved integration and iteration at each step to find the best correlation solution by which all constraints agreed within the flexibility of the components and data set. Conodont picks and the two global carbon isotope excursions of the data set (Lower and Upper Kellwasser events) were firm markers with virtually no flexibility during iteration; however, the exact placement of paleomagnetic chron boundaries could vary (by up to tens of meters in some cases) between sample points and depending on the interpreted limits of mixed polarity packages. Similarly, regional isotope excursions in stratigraphically expanded sections within a single conodont biozone occasionally had more than one correlation possibility. In terms of sequence stratigraphy, platform-top sections were fixed benchmarks for the slope where there was stratigraphic overlap, but isotopic expression provided constraint for sequence definition away from platform control. These combinations of relatively precise and broad controls gave flexibility in iteration to a final set of constraints and sequence stratigraphy, in which all pinning points were honored and in agreement (with none violated). 

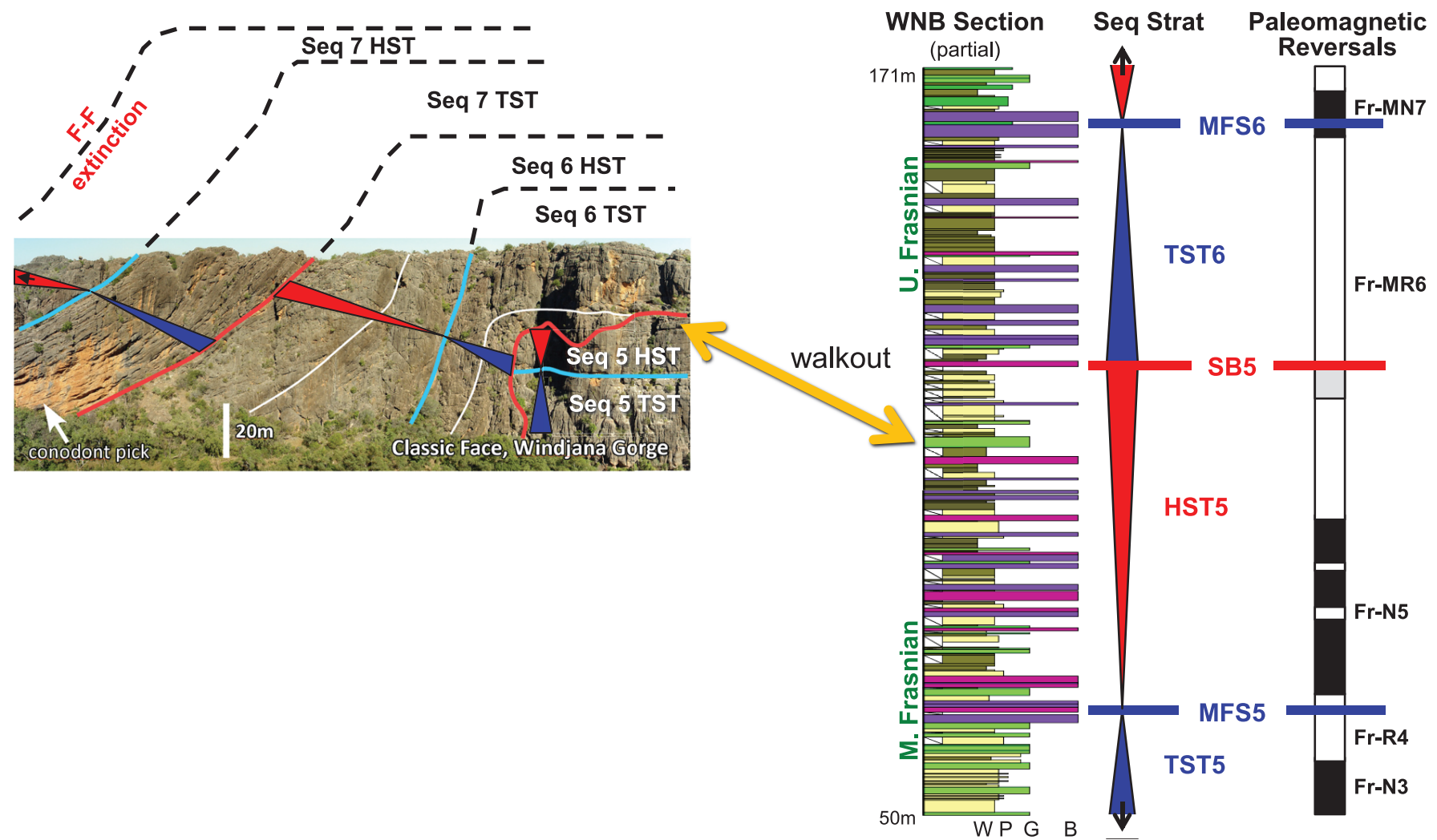

FIG. 7.-Walkout correlation between the Classic Face in Windjana Gorge and the WNB measured section (interpretation and age context for Classic Face after Playford et al. 2009, Playton and Kerans 2015a). Coarse stratigraphic context extrapolated from Classic Face to WNB was sufficient to calibrate Middle vs. Upper Frasnian intervals and to correlate reversals into conodont-constrained slope sections. See Figure 2 and Appendix 1 for sequence architecture and measured section legend, respectively. See Figure 6 for reversal chart. Seq = sequence; SB = sequence boundary; MFS = maximum flooding surface; TST $=$ transgressive systems tract; HST $=$ highstand systems tract; F-F $=$ FrasnianFamennian; $\mathrm{W}=$ wackestone; $\mathrm{P}=$ packstone; $\mathrm{G}=$ grainstone; $\mathrm{B}=$ boundstone.

There were no cases in which constraints overrode others of equal confidence to establish correlation, and the rocks themselves were used for sequence interpretation only within the boundaries of the surrounding controls (i.e., conceptual sequence models did not govern the interpretation of the constraints). This agreement across multiple independent data types built confidence that the chronostratigraphic signals were uncompromised and the sequence stratigraphic framework is valid.

Once completed, the finalized suite of correlations and pinning points allowed the construction of an improved Middle-Late Devonian stratigraphic chart that highlights the qualitative age relationships between conodont biozones, polarity reversals, carbon isotope events, and carbonate sequence development (Fig. 6) Twenty-seven paleomagnetic chrons were defined, about two-thirds of which are considered medium-high in confidence and correlatable across the data set, with the remainder likely valid but not defendable due to lack of stratigraphic overlap. Eleven carbon isotope events were defined, with two linked to the global reference and considered high-confidence, seven considered medium-high confidence with repeatability around the data set but not linked to the global reference, and two considered lower-confidence because of a lack of stratigraphic overlap but linked to the global reference. Twelve composite sequences (likely third-order; sensu Goldhammer et al. 1991) and their systems tracts were identified: two in the Givetian, seven in the Frasnian (after Playton 2008; Playford et al.
2009; Playton and Kerans 2015a, 2015b), and three in the Famennian. Well-constrained sequence stratigraphic interpretations in Middle Frasnian to Middle Famennian upper, middle, and lower slope and basinal settings were achieved for the first time. The Givetian sequences were largely defined by one-dimensional, platform-top stacking pattern analysis and were not tied to any preexisting framework, whereas Frasnian Sequences 1 through 3 were poorly sampled in this study and were based largely on the work of Playford et al. (2009). Frasnian Sequences 4 through 7 were refined after Playford et al. (2009) and Playton and Kerans (2015a) and were very well constrained in this study. The Middle-Upper Frasnian boundary was here placed within the composite HST of Sequence 5, slightly different than in previous studies, which defined it at the top of Sequence 5 (Playford et al. 2009, Playton and Kerans 2015a). Famennian Sequences 1 through 3 are well constrained and are defined here for the first time. Sequences could not be distinguished for a portion of the Middle Famennian, as a result of facies homogeneity from pervasive calcimicrobial encrustation and lack of stratigraphic overlap across the data set (Middle Famennian [MFa] in Fig. 6, "Sequences" column). In general, the stratigraphic framework defined here is considered high confidence for Middle Frasnian to Middle Famennian time. Givetian, Early Frasnian, and MFa intervals were well sampled and contributed robust data profiles, but either lacked sufficient stratigraphic overlap with other 

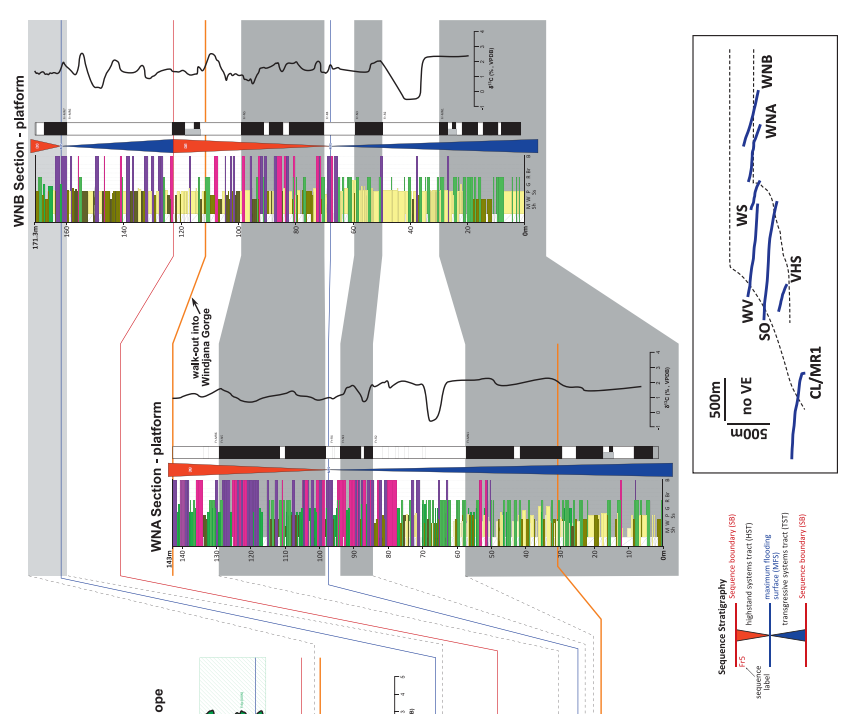

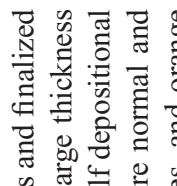

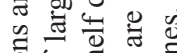

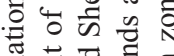

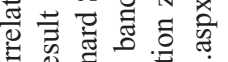

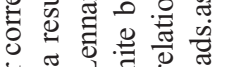

可 of on

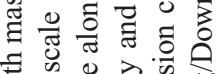

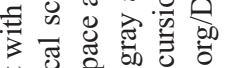

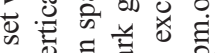

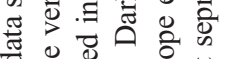

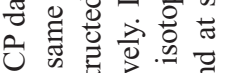

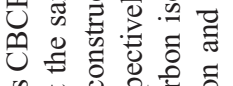

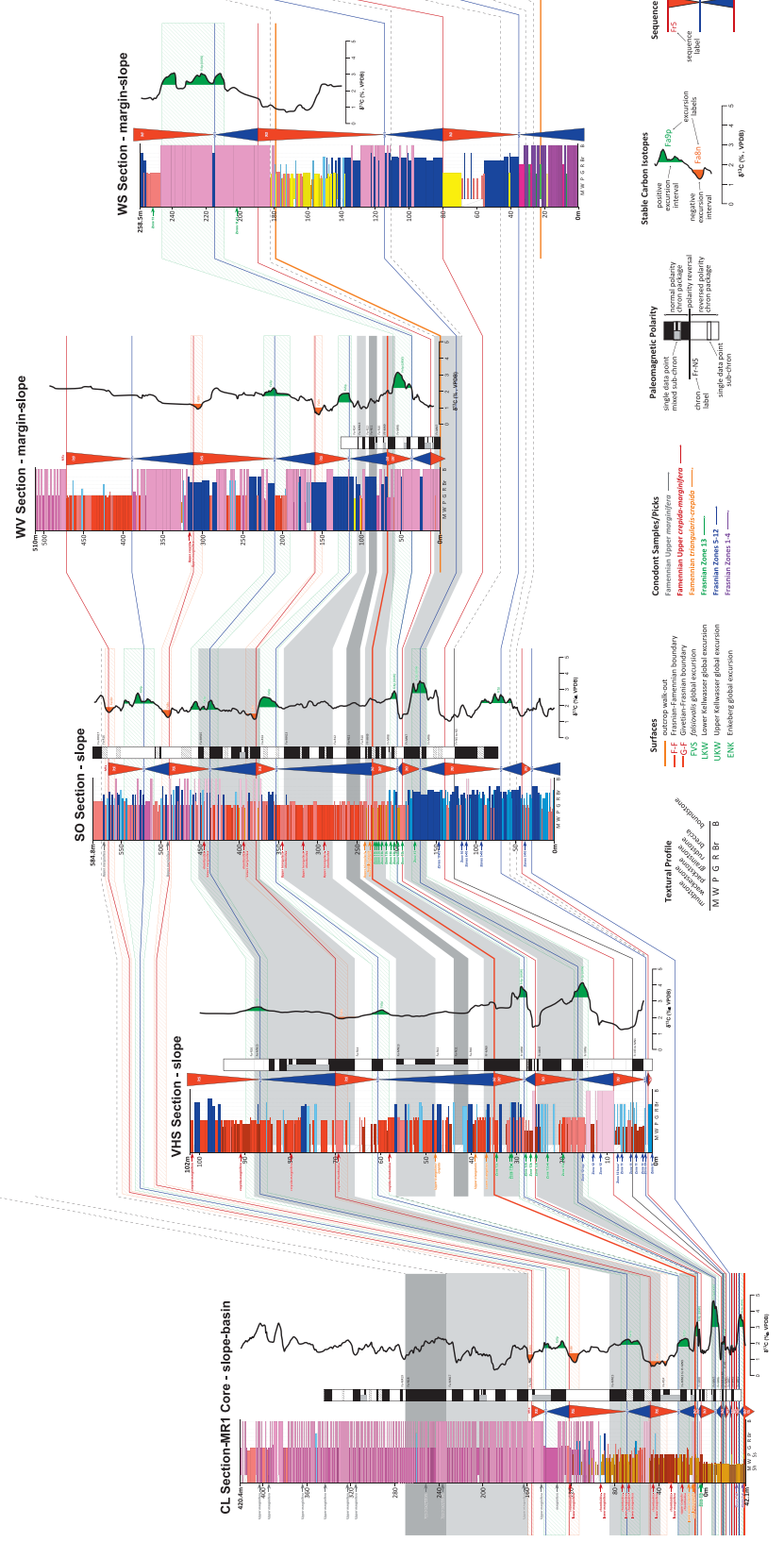

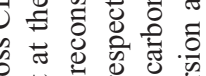

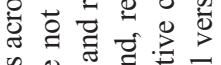

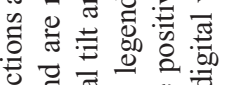

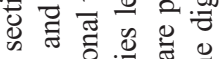

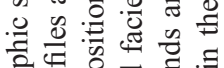

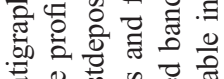

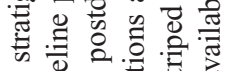

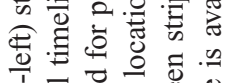

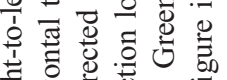

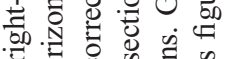

要

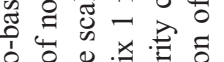

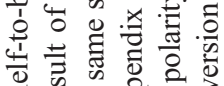

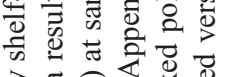

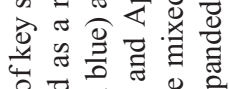

잉

言言 要吾安

해음

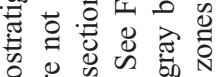

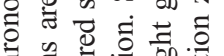

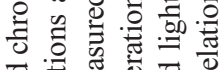

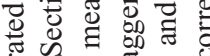

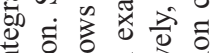

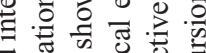

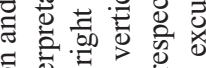

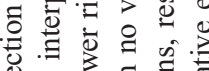

娚

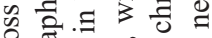

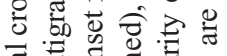

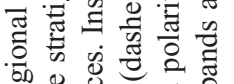

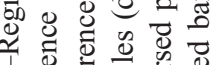

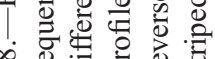

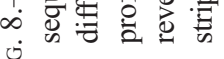


transects for repeatability or had insufficient biostratigraphic control to be considered higher confidence.

In addition to regional correlations and stratigraphic relationships, this linkage of physically disconnected localities allows for the development of new representations of the Lennard Shelf Devonian carbonate system. The significantly increased correlation control provides an opportunity to reconstruct the carbonate system with greater accuracy than was available before, both in terms of scale and the actual geometrical relationships of the shelf-to-basin stratigraphic system and sequence architecture (Figs. 9, 10). Although the data set as a whole trends mostly along the strike of the Devonian carbonate system (Fig. 1), a fairly uniform sampling of the different depositional environments allows for reconstruction of a collapsed, dip-oriented composite regional cross section. In addition to the integrated stratigraphic constraints, reconstruction of the stratal architecture entailed (1) honoring the actual transect surface topography and depositional dip data collected along transects (corrected for tilt through geopetal measurement), (2) the use of previous work to follow the large-scale backstepping to prograding evolution (Playford et al. 2009), and (3) estimates of platform thicknesses, backstepping distances, underlying topography, and spatial transect placement. Once the stratal framework was constructed true to scale and with no vertical exaggeration, rock data along transects were control points for interpreting the shelf-tobasin facies distributions.

These results advance our understanding and ability to characterize the carbonate system along the Lennard Shelf in several respects (Table 5), including the following: (1) high-resolution correlation of disconnected localities over approximately $200 \mathrm{~km}$ (previously no possible), spanning the Windjana Gorge, South Oscar Range, Horse Spring, and Casey Falls areas; (2) upper-middle-lower slope and basin correlation for the Middle Frasnian to Middle Famennian and platform to basin correlation across the supersequence MFS; (3) scaled shelf-to-basin composite reconstruction of the system tied to numerous transects and honoring all depositional information; (4) refinement of the Frasnian composite sequences and their relationship with the conodont zones; (5) definition of three Lower to Middle Famennian composite sequences and their systems tracts and (6) definition of the expression of sequences and systems tracts within slope strata. A detailed comparison between the results of this study and the interpretations of Playton and Kerans (2015a, 2015b) is presented later (see Discussion), focusing on aggradationa escarpments during supersequence TSTs, periods of sustained collapse around supersequence MFSs, pre- and post-F-F extinction impacts on slope deposition, and hierarchical trends observed in slope deposits.

In addition to the above, recognition of a conspicuous Middle Famennian interval (MFa; Figs. 6, 9; Table 5) warrants extra discussion and requires further work. This progradational interval appears to represent a Famennian carbonate system that evolved into one dominated by platform-top grain shedding with simultaneous, extensive microbial encrustation down to water depths not observed in any other outcrop or subsurface data sets $(>>500 \mathrm{~m}$ downslope; see Playton et al 2010, Playton and Kerans 2015b for discussion of deep boundstone margin analogs). We are unable to further delineate the MFa internally as a result of lack of stratigraphic overlap (CL Section contains the only record; Appendix 8) and a grain-dominated, boundstone-encrusted grainstone succession that obscures facies stacking analysis. However, Hillbun et al. (2016) subdivides the MFa interval into four composite sequences (Famennian Sequences 4-7; see their figs. 2, 6) based solely on isotopic expression observed in the CL measured section (Appendix 8 ) and the proxy developed for systems tract interpretation in slope settings. Despite the many remaining questions on this peculiar interval, the MFa marks the final phase of reefal platform development along the Lennard Shelf prior to transition into a more cold-water-assemblage, distally steepened ramp of the Late Famennian-Tournaisian (Fairfield Group; Playford et al. 2009).

\section{MARGIN-TO-BASIN SEQUENCE STRATIGRAPHIC MODELS}

The resultant reconstructed shelf-to-basin sequence architecture and facies mosaic depiction of the Lennard Shelf highlights slope types and margin styles across the Middle-Late Devonian supersequence and F-F extinction interval. It also allows a spectrum of analysis and comparisons not previously possible. The following sections will describe in detail the development of six composite sequences, the Frasnian 4 through 7 and Famennian 1 to 2 sequences, as they evolved from supersequence TST, MFS, and HST accommodation conditions and as they progressed through the lead-up and recovery periods associated with the F-F extinction (Figs. 9, 10)

\section{Lower-Middle Frasnian Composite Sequence 4}

Lower-Middle Frasnian Sequence 4 was deposited in the supersequence TST when margins and sequences backstepped relative to one another with intervening pulses of aggradation (Fig. 10). The TST of Sequence 4 exhibits the development of a growth escarpment (after Playton et al. 2010), in which vertical margin aggradation eventually outpaced its coeval foreslope deposits, resulting in onlapping slope stratal geometries (Fig. 11A). The overall setting was stable as the margin stacked vertically upon solid underlying foundations. Consequently, foreslopes were grain-dominated from platform-top shedding, with little debris generated from collapse. However, there was a point at which the vertical escarpment margin constructed enough relief and slope profiles became significantly underfilled such that the profile became highly susceptible to collapse triggers. During this time in the Late TST, the margin tended to fail at various points along strike, generating reentrant paleogeography and debris deposits that came to rest on the slope and periodically in the basin (Fig. 11B). At the MFS, the margin backstepped and reinitiated landward of the previous margin and began to construct relief (Fig. 11C). Foreslope systems were poorly developed at this time and were composed of a grain-dominated veneer that draped the former slope profile and infilled around debris topography. In the HST, margins were accretionary, weakly prograded, and maintained stability as a result of the solid substrate of the relict platform-top; thus, foreslopes were grain-dominated from platform-top shedding and contained little debris from margin collapse (Fig. 11D). Variations in this sequence model entail greater backstepping distances where weakly prograding HSTs did not advance to the former margin, producing a net backstepped sequence (see Playton and Kerans 2015a).

The most distinctive stacking pattern is best expressed in the middle slope and is symmetrical, with a concentration of debris just beneath the MFS that is bracketed below and above by graindominated deposits (Figs. 12, 13A). This particular pattern is dependent on the position (in both a dip and a strike sense) of the debris accumulation as the deposits were strike discontinuous and could occur kilometers into the basin or freeze in steeper middleslope settings. Thus, in some cases the entire middle-slope sequence may consist only of stacked grain-dominated deposits. The margin also exhibits an obvious stacking pattern, with slope deposits overlying platform-top facies, highlighting backstepping at the MFS. A shallowing upward succession, often comprised of sediment gravity flows overlain by in situ margin deposits, is common above the previously transgressed platform-top facies. The silt-dominated basinal setting does not display a clear stacking pattern, but slight increases in grain content are observed immediately beneath the 

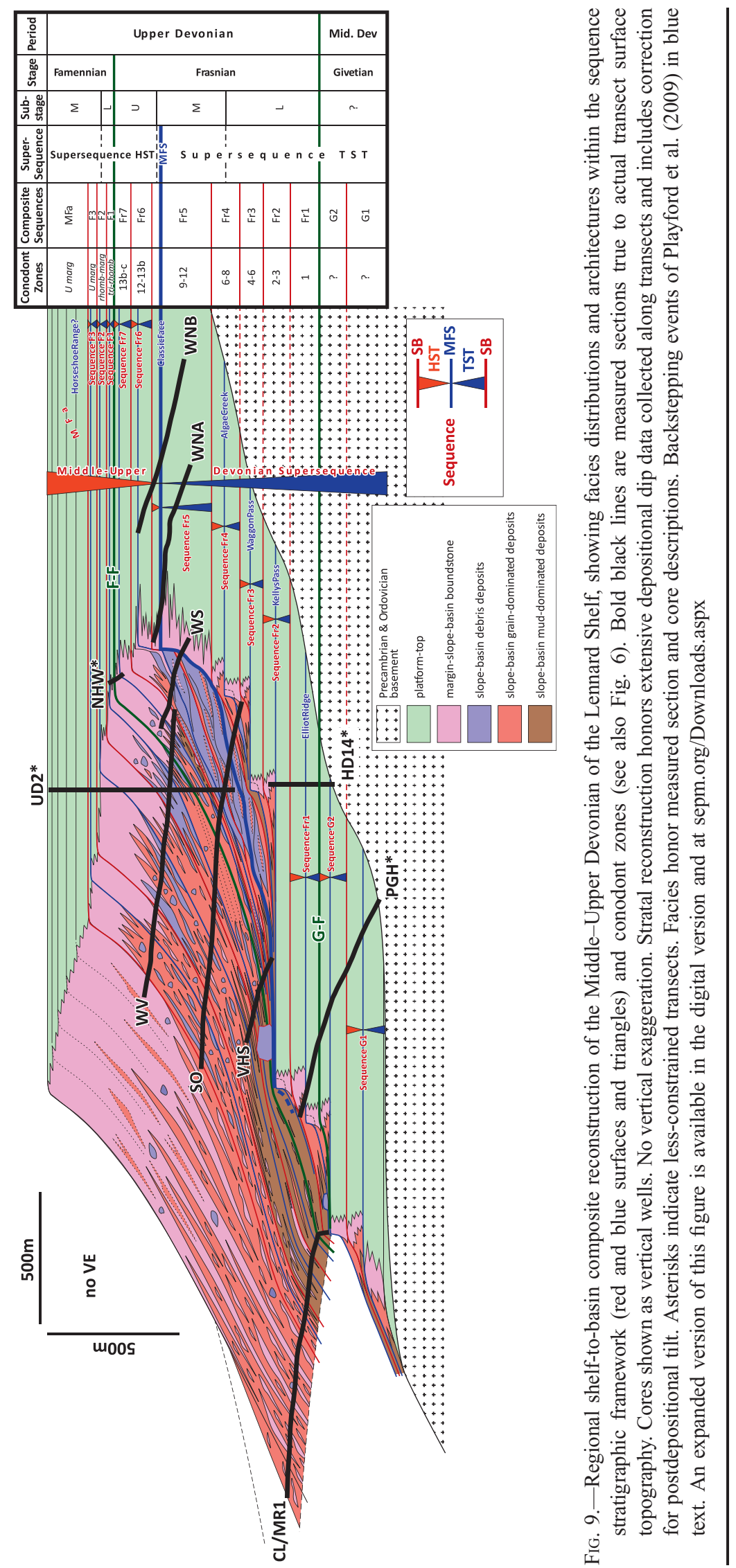
A)

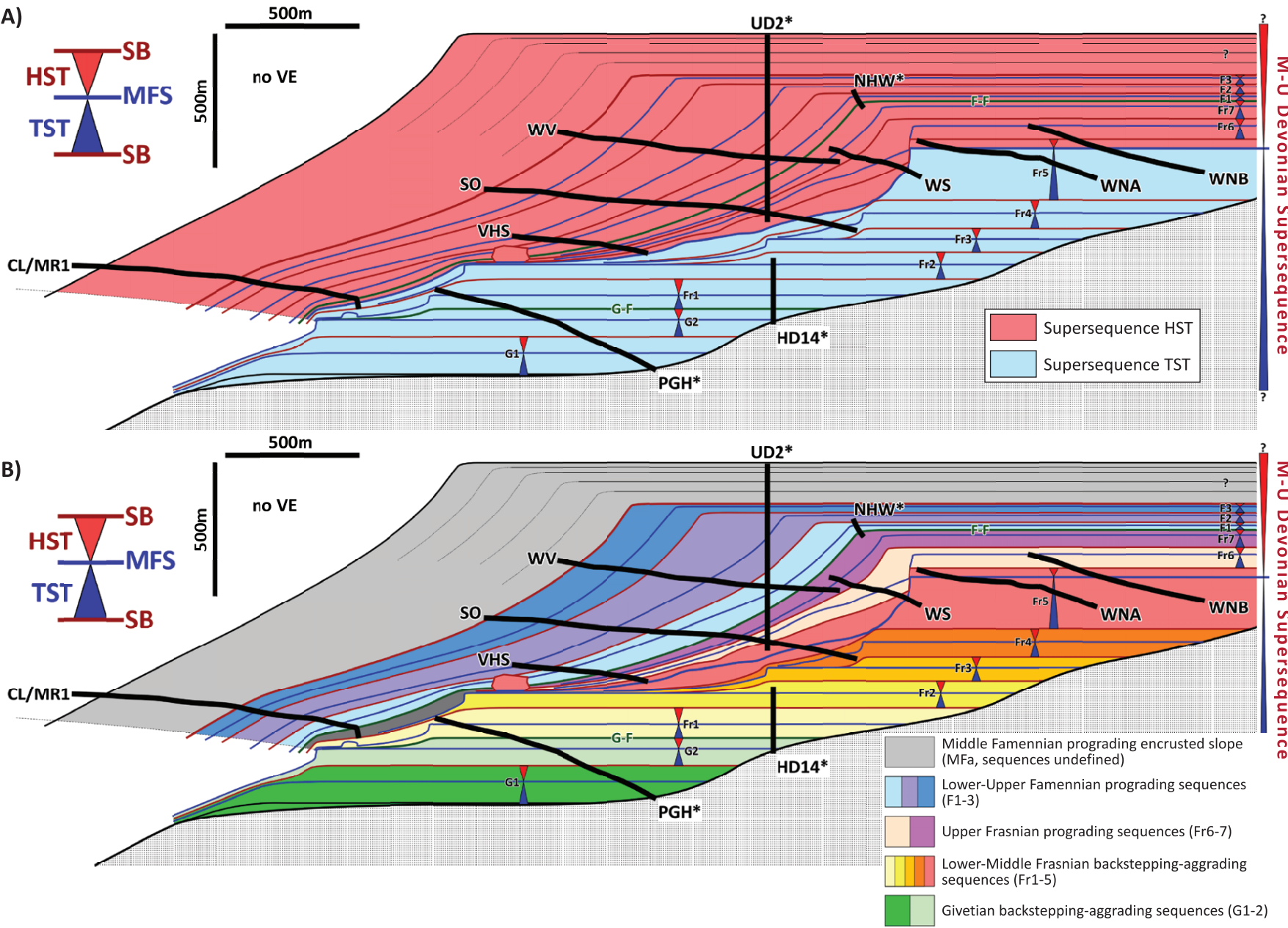

FIg. 10.-Hierarchical supersequence and composite sequence framework for the Middle-Upper Devonian of the Lennard Shelf. Bold black lines are measured sections true to actual surface topography and corrected for tilt. Asterisks denote less-constrained transects chronostratigraphically. G-F = Givetian-Frasnian boundary; F-F = Frasnian-Famennian boundary; Middle-Upper Frasnian boundary occurs within HST of Sequence 5 (Fr5). A) Supersequence architecture of the Lennard Shelf. Blue shading defines the supersequence TST, red shading defines the supersequence HST, and the supersequence MFS is the boundary between blue and red fills in the uppermost Middle Frasnian. B) Composite sequence architecture of the Lennard Shelf. Red and blue triangles denote systems tracts, and red and blue lines denote sequence boundaries and maximum flooding surfaces, respectively. Gray shading indicates undefined Middle Famennian strata (MFa interval).

MFS and in the Late HST, possibly reflecting very distal equivalents of debris deposition and maximum progradational extent, respectively.

\section{Middle-Upper Frasnian Composite Sequence 5}

Middle-Upper Frasnian Sequence 5 is where the supersequence MFS is defined, the point at which margins began to shift from longterm backstepping and aggradation to progradation (Fig. 10). In the Early TST of Sequence 5, aggradational escarpments were again developed through vertical aggradation of the margin and the inability of foreslope deposits to fill the slope profile to the level of the coeval margin; this underfilling was amplified as a result of the inherited relief from underlying backstepped topography (Fig. 14A). This style of vertical margin growth was initially stable, and grain-dominated slopes developed accordingly. By Late TST time, the margin had constructed considerable relief, the slope profile was substantially underfilled, and margins were consequently more likely to collapse (Fig. 14B). Hence, margins underwent sustained mass wasting and evolved into an erosional escarpment with associated debrisdominated slopes that onlapped lower down in the profile. In the HST of Sequence 5, margins, already unstable, were unable to prograde over dramatically underfilled profiles with insufficient substrate. This resulted in sustained instability and mass wasting, debris-dominated slope development, and the continuation of an erosional-escarpment margin configuration (Figs. 13C, 14C).

Most of the slope consists of thick, amalgamated successions of debris with unclear stacking organization (Fig. 15). At the margin, scarps of truncated platform strata with onlapping debris are observed (Fig. 13C). The lower slope records the grain-dominated toesets that are equivalent to updip debris. A more silt-dominated interval (silt-sized carbonate and quartz grains) brackets the MFS, 


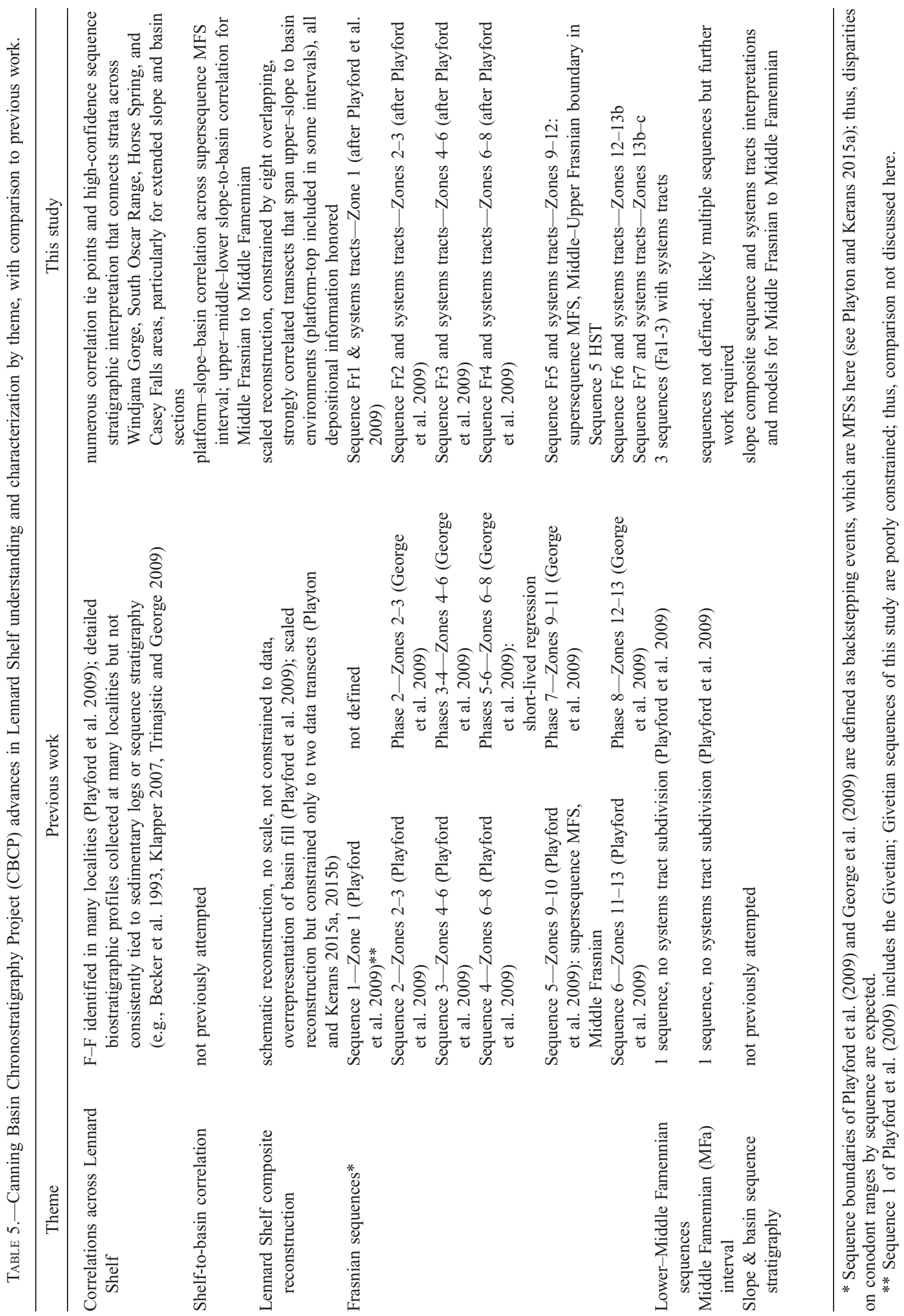




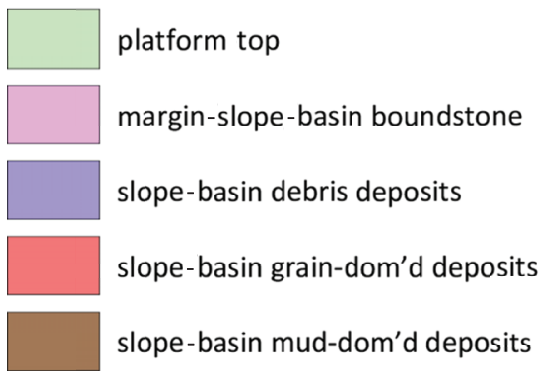

Frasnian Sequence 4
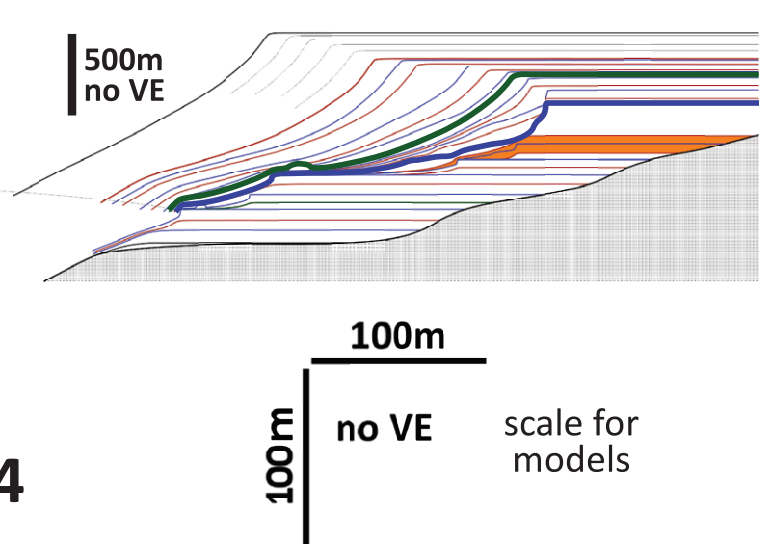

D) HST

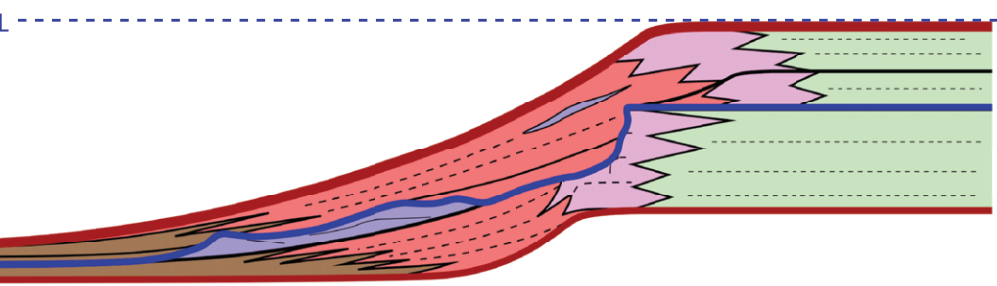

C) MFS-Early HST
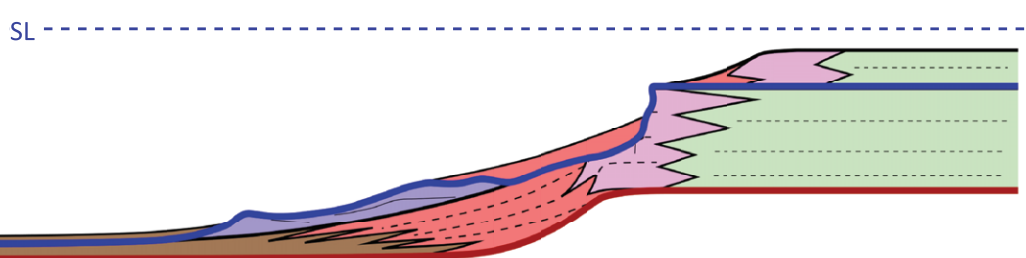

B) Late TST

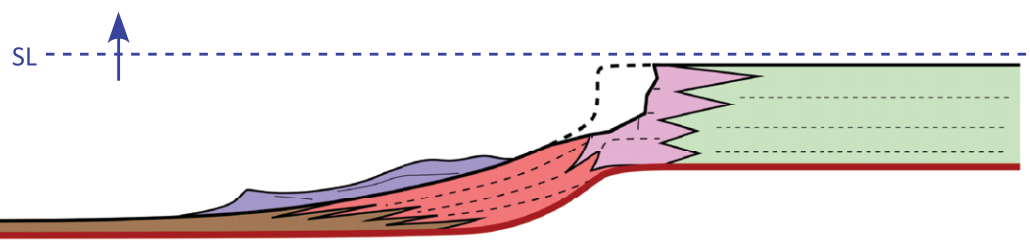

A) TST

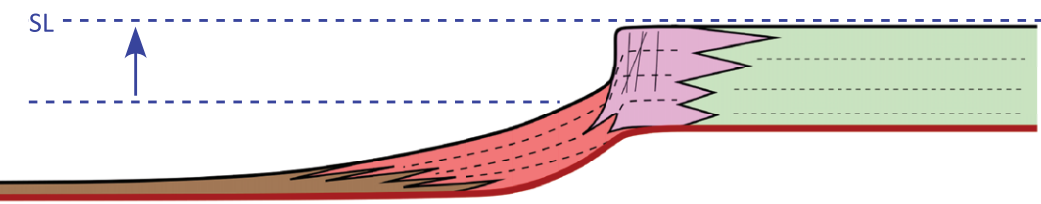

FIG. 11.-Lower-Middle Frasnian Composite Sequence 4 margin-to-slope development within the supersequence TST when margins were undergoing long-term backstepping. Red lines are sequence boundaries, and blue line is maximum flooding surface. In upper right inset, placement within supersequence architecture shown in orange, and blue and green lines are supersequence MFS and F-F boundary, respectively. dom'd = dominated. A) TST setting: margins evolved into escarpments through aggradation and had associated grain-dominated foreslopes. Margins became increasingly sensitive to collapse triggers. B) Late TST setting: margins failed, producing reentrants and debris in slope or basinal settings. C) MFS-Early HST setting: margins backstepped at the MFS, reinitiated, and began to construct relief. The former slope profile was draped with bypassed sediment. D) HST setting: margins weakly prograded and had associated grain-dominated foreslopes. 


\section{Frasnian Sequence 4}

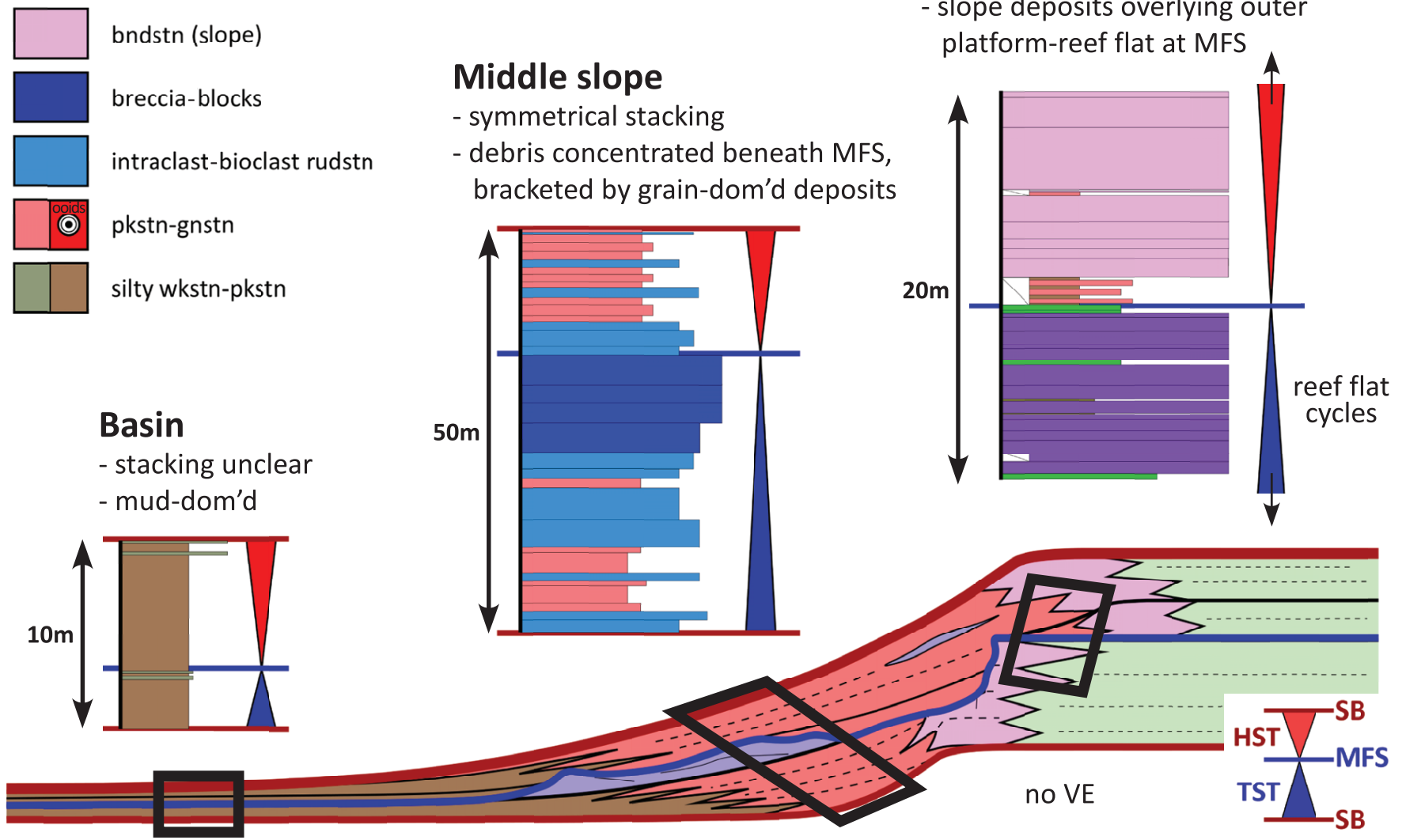

FIG. 12.-Lower-Middle Frasnian Composite Sequence 4 stacking patterns for margin, middle-slope, and basinal environments. Color legend pertains to measured sections. See Figure 11 for supersequence context and model color scheme. See Appendices for measured sections. Margin succession is from the PGH measured section and is used as a proxy for Sequence 4. Middle-slope succession is from the SO measured section. Basin succession is from the MR1 Winkie core. dom'd = dominated; bndstn = boundstone; rudstn = rudstone; gnstn = grainstone; pkstn = packstone; wkstn = wackestone.

producing a symmetrical stacking pattern; the lack of grainy material around the MFS may indicate backfilling of the slope in an updip position at that time. The basinal setting is again not highly diagnostic but shows a vague upward decrease in silt content starting within the TST; this timing may be coeval with the onset of escarpment mass wasting and is reflected in the basin with a slight increase in grain export.

\section{Upper Frasnian Composite Sequence 6}

Upper Frasnian Sequence 6 is in the Early HST of the supersequence, when margins were unable to prograde, despite lower-accommodation conditions, as a result of inherited underfilled profiles with inadequate substrates to support progradation (Fig. 10). The TST of Sequence 6 inherited the highly unstable profile from Sequence 5 , prompting continued mass wasting during aggradation and an erosional escarpment configuration with associated debrisdominated foreslopes (Fig. 16A). In the Early HST, margins were able to prograde to a point, but subsequently failed; this occurred in pulses and episodically as the system neared the final stages of slope regrading and equilibration (Fig. 16B). These represent the last phases of downslope debris shedding and completion of slope profile infilling such that an angle-of-repose substrate was established for progradation. Once the debris substrate was fully developed by the Late HST, the margin was able to prograde and evolved into an accretionary margin with shelf-to-slope interfingering relationships (Fig. 16C). During this final stage of Sequence 6, slopes were graindominated, reflecting that the margin had reached stability (Fig. 13B, D).

Sequence 6 stacking patterns for middle- and upper-slope settings exhibit an upward transition from debris-dominated to graindominated deposits, reflecting the shift from mass wasting to stable progradation (Figs. 13B, 13D, 17). Boundstone tongues are also observed in upper-slope successions during the early pulses of progradation in the Early HST. Lower-slope and basinal settings both display upward increases in platform-top-derived material, again reflecting updip debris backfilling processes that transition into offbank shedding during progradation. In lower-slope settings during the TST, microbial boundstone bioherms occur locally, creating positive topography within a more silt-dominated seascape; thus, lower-slope TST stacking patterns can vary laterally from purely boundstone to silty strata. 


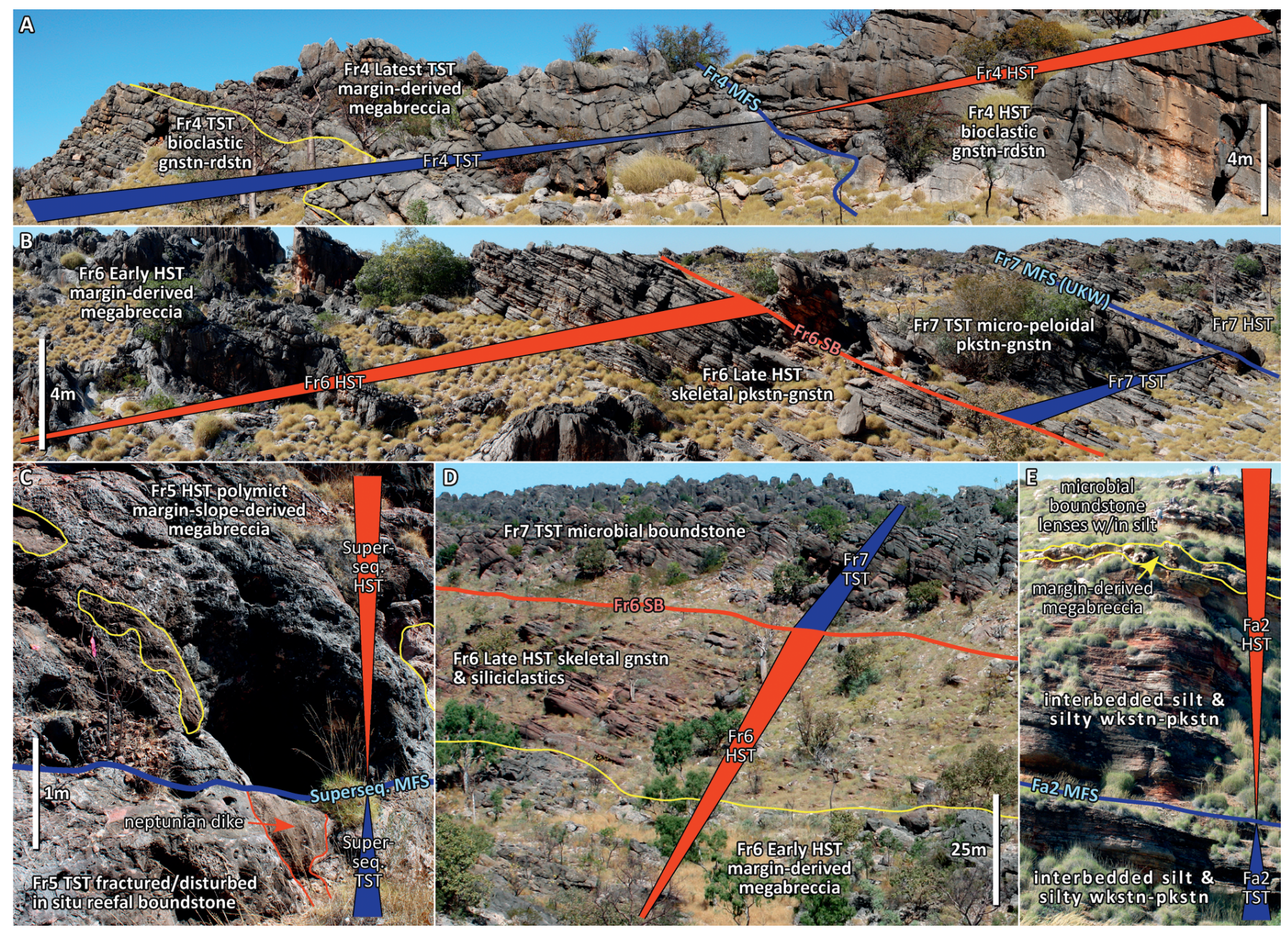

FIG. 13.-Outcrop photographs of systems tracts and significant sequence stratigraphic surfaces recorded in margin, slope, and basinal strata. rudstn $=$ rudstone; gnstn $=$ grainstone; pkstn $=$ packstone; wkstn $=$ wackestone. A) Frasnian Composite Sequence 4 (Fr4) TST to HST succession recorded in middle slope setting, along SO transect (Appendix 6). Symmetrical pattern of megabreccia interval bracketed by grain-dominated deposits is observed, representing Early TST grain shedding during aggradation, Late TST margin collapse, backstepping at the MFS, and HST grain shedding. B) Upper portion of Frasnian Composite Sequence 6 (Fr6) and lower portion of Frasnian Composite Sequence 7 (Fr7) recorded in middle slope setting, along SO transect (Appendix 6). Fr6 shows transition from debris-dominated to graindominated slopes reflecting slope readjustment subsequent to the supersequence MFS. Abrupt change in grain composition is observed in Fr7, likely related to pre-extinction effects. Fr7 MFS coincides with the Upper Kellwasser isotopic event (UKW). C) Supersequence MFS in margin position with megabreccia deposits abutting fractured in situ reefal facies, along WS transect (Appendix 4). Supersequence MFS coincides with Frasnian Composite Sequence 5 (Fr5) MFS. Fr5 HST megabreccia deposits are younger than collapse events that formed the erosional scarp during the TST of Fr5. D) Upper portion of Fr6 and lower portion of Fr7 recorded in upper-to-middle slope setting, along WS transect (Appendix 4). Debris-dominated to grain-dominated slope deposition can be observed in the Fr6 HST. The TST of Fr7 is marked by an abrupt downslope expansion of the microbial boundstone factory, interpreted to be related to pre-extinction effects. E) Famennian Composite Sequence 2 (Fa2) TST to HST succession recorded in toe-of-slope setting, along CL transect (Appendix 8). Stratigraphic thickness shown is approximately $40 \mathrm{~m}$. Interbedded silt and silty wackestone-packstone dominate the overall succession, with conspicuous debris horizons and boundstone lenses present in the HST.

\section{Upper Frasnian Composite Sequence 7}

Upper Frasnian Sequence 7 is in the Early HST of the supersequence, when margins were stably prograding; however, this sequence was also the prelude to the F-F boundary, during which changing ecological variables were beginning to affect sediment factories that contribute to slope and basin deposition (Fig. 10). The TST of Sequence 7 exhibits an aggradational margin with a significantly expanded upper-slope microbial boundstone setting, where encrustation became dominant up to $200 \mathrm{~m}$ downslope from the platform edge, based on reconstructed water depth (Figs. 13D, 18A). A unique upper-middle-slope style also developed, compris- 


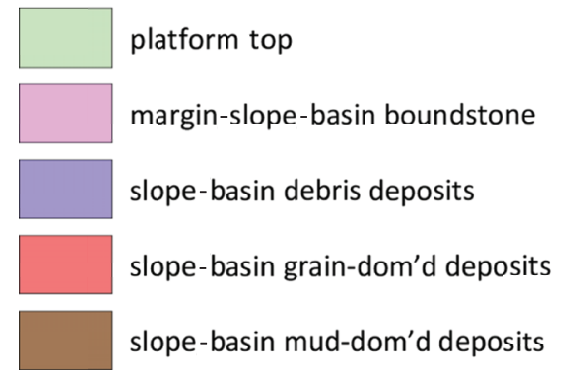

Frasnian Sequence 5

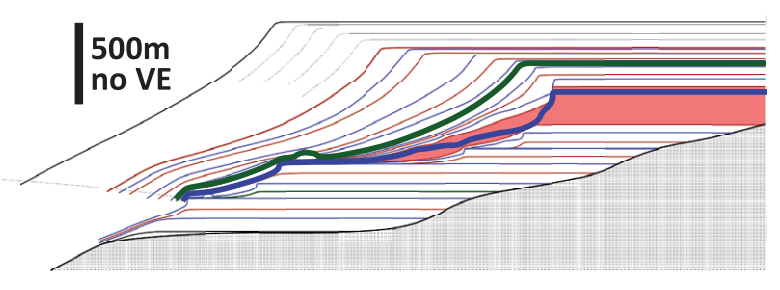

$200 \mathrm{~m}$

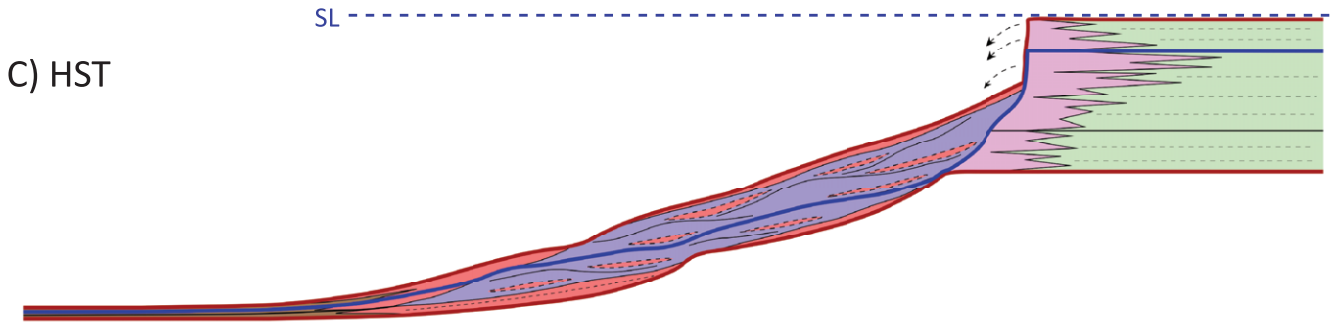

B) Late TST
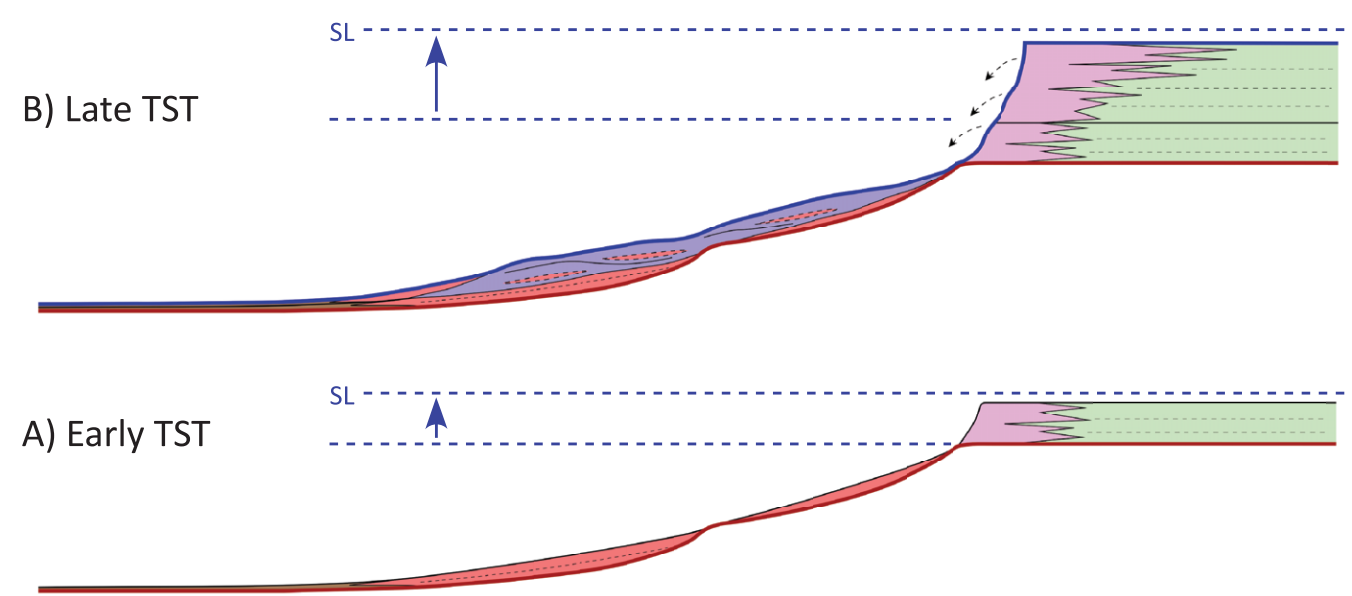

FIG. 14.-Middle-Upper Frasnian Composite Sequence 5 margin-to-slope development bracketing the supersequence MFS when margins underwent the long-term transition from backstepping and aggradation to progradation. Red lines are sequence boundaries and blue line is maximum flooding surface. In upper right inset, placement within supersequence architecture shown in red, and blue and green lines are supersequence MFS and F-F boundary, respectively. dom'd = dominated. A) Early TST setting: escarpment margins developed from aggradation with associated grain-dominated foreslopes. B) Late TST setting: margins continued to aggrade, built relief, and developed severe instability, resulting in sustained mass wasting and the formation of an erosional escarpment with associated debris-dominated foreslopes. C) HST setting: margins were unable to prograde over underfilled escarpment profile and consequently failed, maintaining debris-dominated foreslopes and an erosional escarpment configuration.

ing a mixed siliciclastic-carbonate silt-dominated terrain with numerous gullies that served as conduits for bypassing material. The middle slope is accordingly grain-dominated, as it was the recipient of the bypassed material, although these grain-dominated deposits are conspicuously micropeloidal, with intermixed silt (vs. more typical skeletal-peloidal-coated grain assemblages; Fig. 13B). In general, the TST slopes were rather poorly developed, with representative grain and debris contributors evidently subdued in productivity and/or downslope shedding. The HST of Sequence 7 exhibits fairly strong margin progradation and maintains the deep microbial boundstone upper-slope factory (Fig. 18B). The slopes were mixed debris- and grain-dominated, indicating that more typical platform-top and margin shedding processes had resumed after the TST. 


\section{Frasnian Sequence 5}

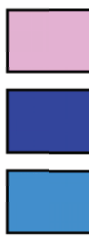

bndstn (slope)

breccia-blocks

intraclast-bioclast rudstn

(2) pkstn-gnstn

silty wkstn-pkstn
Middle slope

- stacking unclear

- amalgamated stacks of debris
Upper slope

- debris deposits

onlapping scarp

\section{Lower slope}

Basin

- symmetrical stacking

- overall coarsening - mud-dom'd around MFS upward - mud-dom'd
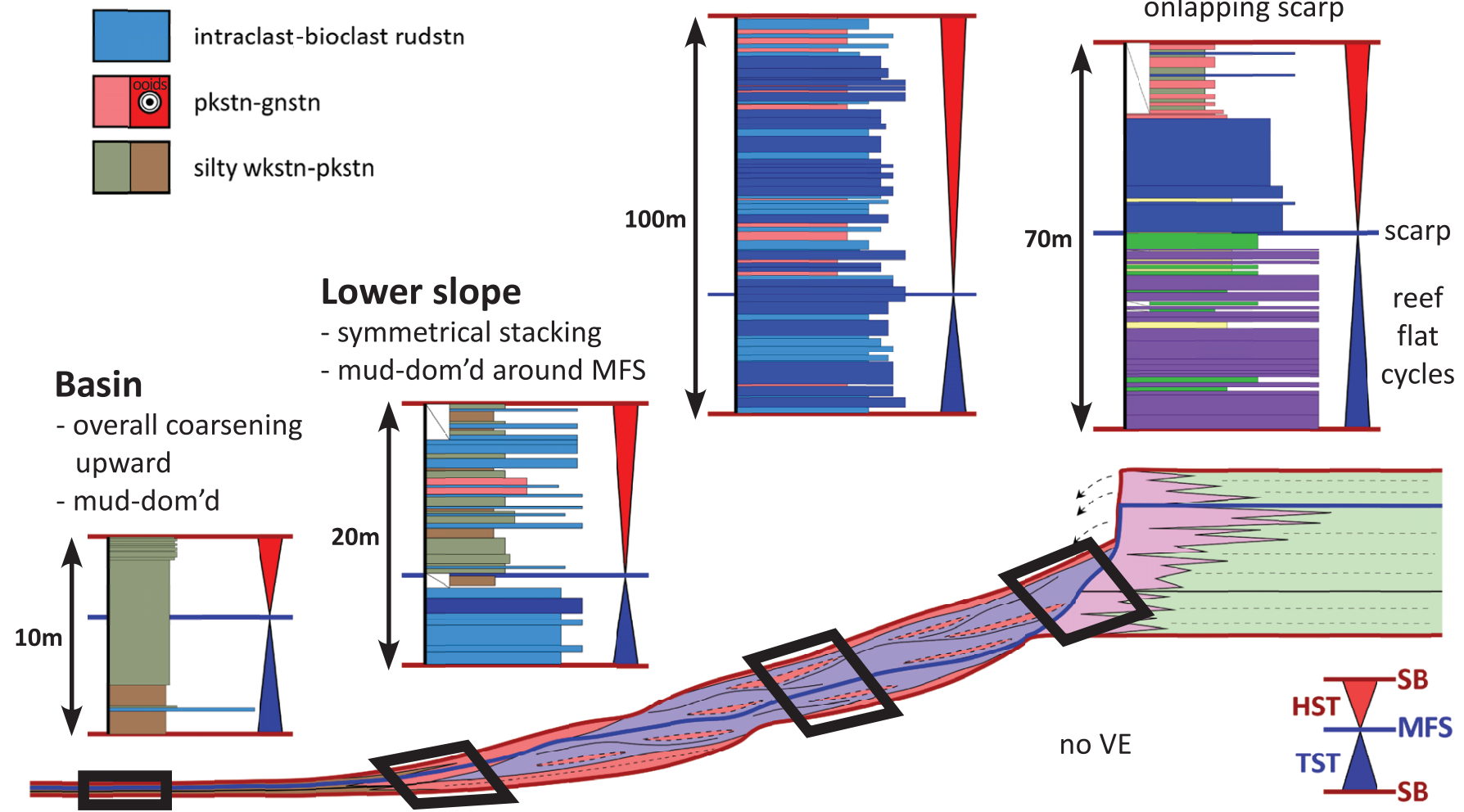

no VE

FIG. 15.-Middle-Upper Frasnian Composite Sequence 5 stacking patterns for upper-slope, middle-slope, lower-slope, and basinal environments. Color legend pertains to measured sections. See Figure 13 for supersequence context and model color scheme. See Appendices for measured sections. Upper-slope succession is from the WS measured section. Middle-slope succession is from the SO measured section. Lower-slope succession is from the VHS measured section. Basin succession is from the MR1 Winkie core. dom'd = dominated; bndstn = boundstone; rudstn = rudstone; gnstn = grainstone; pkstn = packstone; wkstn = wackestone .

The stacking patterns of Sequence 7 (Fig. 19) are symmetrical in the lower and middle slope, in that debris deposits are concentrated in the Early HST, possibly indicating greater margin instability at the onset of composite-scale progradation. The TSTs of middle- and lower-slope settings will vary in character (thus, the stacking pattern will vary) depending on the exact profile position of the siltdominated gullied slope setting or downdip grain-dominated apron. The Late HSTs of middle- and lower-slope settings tend to both exhibit upward successions from grain- to mud-dominated deposits, possibly reflecting the gradual decline of platform-top carbonate factory production as the $\mathrm{F}-\mathrm{F}$ event was approached. Upper-slope stacking is unclear as it consists dominantly of boundstone related to the development of a well-established encrusted upper-slope setting. Basinal patterns exhibit an upward increase in grain content relative to silt, which likely again reflects an increase in offbank shedding throughout the sequence.

\section{Lower Famennian Composite Sequence 1}

The first composite sequence in the Famennian was progradational, as forced by the supersequence HST setting, and represented the recovery period after the F-F extinction (Fig. 10). The TST of Famennian Sequence 1 has a peculiar architecture, with a middle slope that is thicker than its equivalent upper slope (Fig. 20A). The upper slope reconstructs to be a thin, yet still deep on the slope, veneer of microbial boundstone. The middle slope was dominated by an anomalously thick stack of oolitic-coated grain grainstone, and the lower slope was grain dominated, but with an unusual proportion of debris deposits. We interpret these characteristics together to indicate that the TST of Sequence 1 was a time of subdued margin growth, with slope bypass of material from dominantly platform-top ooid factories. The HST of Sequence 1 was progradational, with a deep boundstone margin, foreslopes that contained substantially more debris deposits than were present in the TST, and an overall 


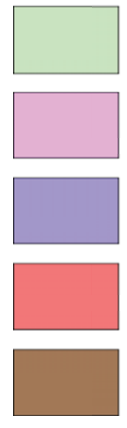

platform top

margin-slope-basin boundstone

slope-basin cebris deposits

slope-basin grain-dom'd deposits

slope-basin mud-dom'd deposits

\section{Frasnian Sequence 6}

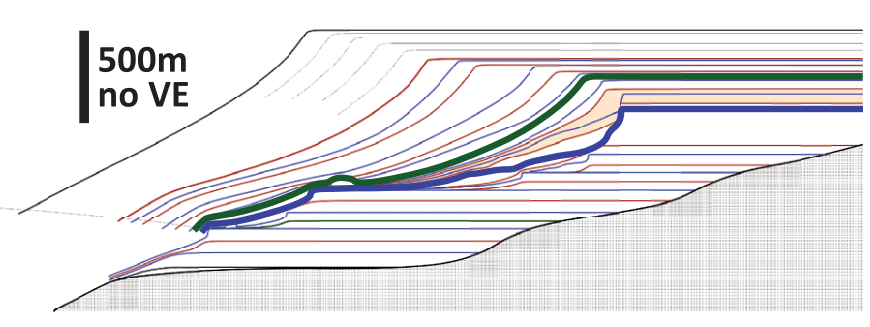

\section{$200 \mathrm{~m}$}

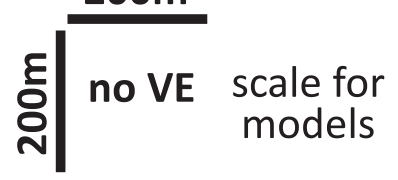

C) Late HST

$$
\mathrm{SL}
$$
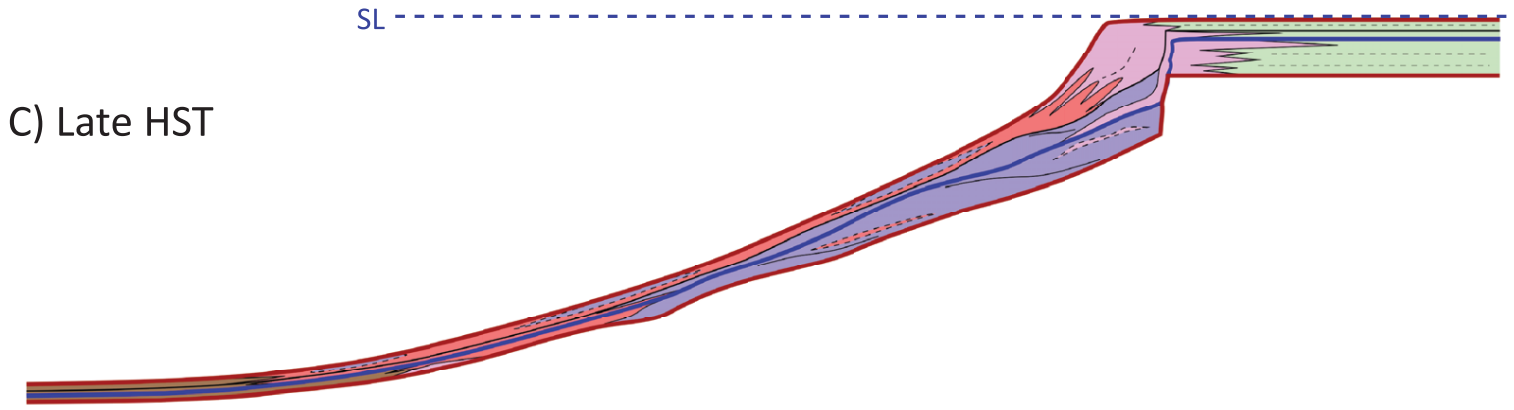

B) Early HST
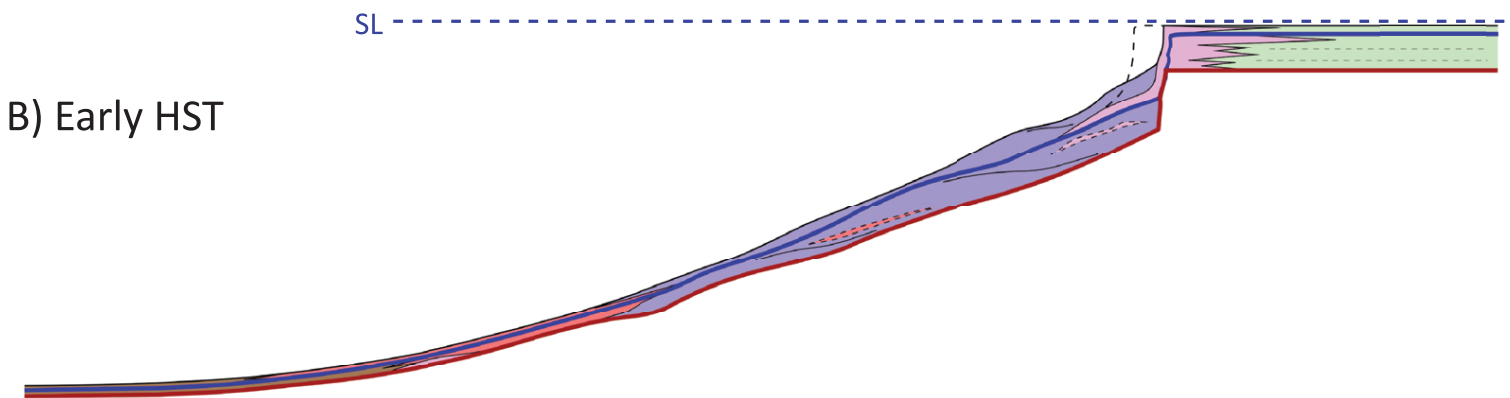

A) TST

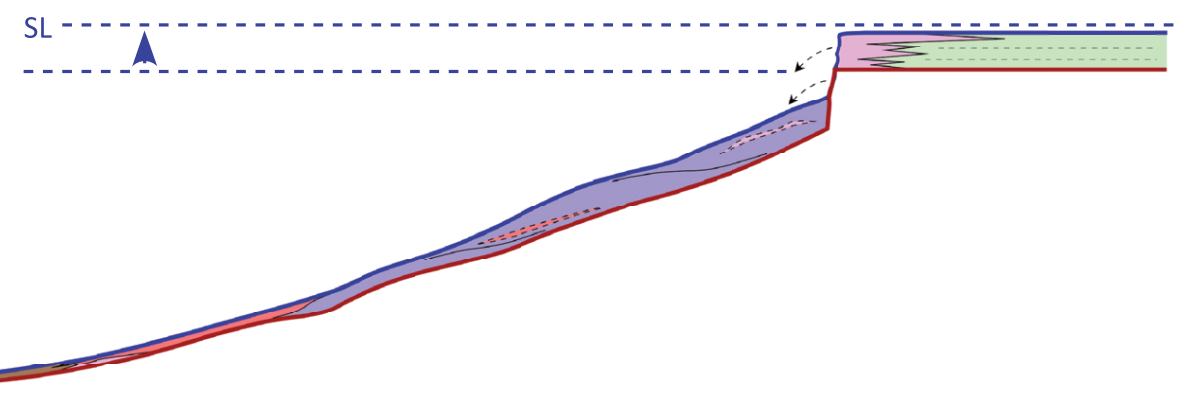

FIG. 16.-Upper Frasnian Composite Sequence 6 margin-to-slope development within the supersequence Early HST when margins were unable to prograde over relict escarpment profiles. Red lines are sequence boundaries and blue line is maximum flooding surface. In upper right inset, placement within supersequence architecture shown in beige, and blue and green lines are supersequence MFS and F-F boundary, respectively. dom'd = dominated. A) TST setting: margin aggradation on inherited escarpment profile resulted in continued instability and mass wasting, with associated debris-dominated foreslopes. B) Early HST setting: pulses of progradation resulted in margin failure, emplacing the final volumes of debris substrate required for progradation. C) Late HST setting: with available debris substrate, margins transitioned into accretionary configurations and prograded with associated grain-dominated foreslopes. 


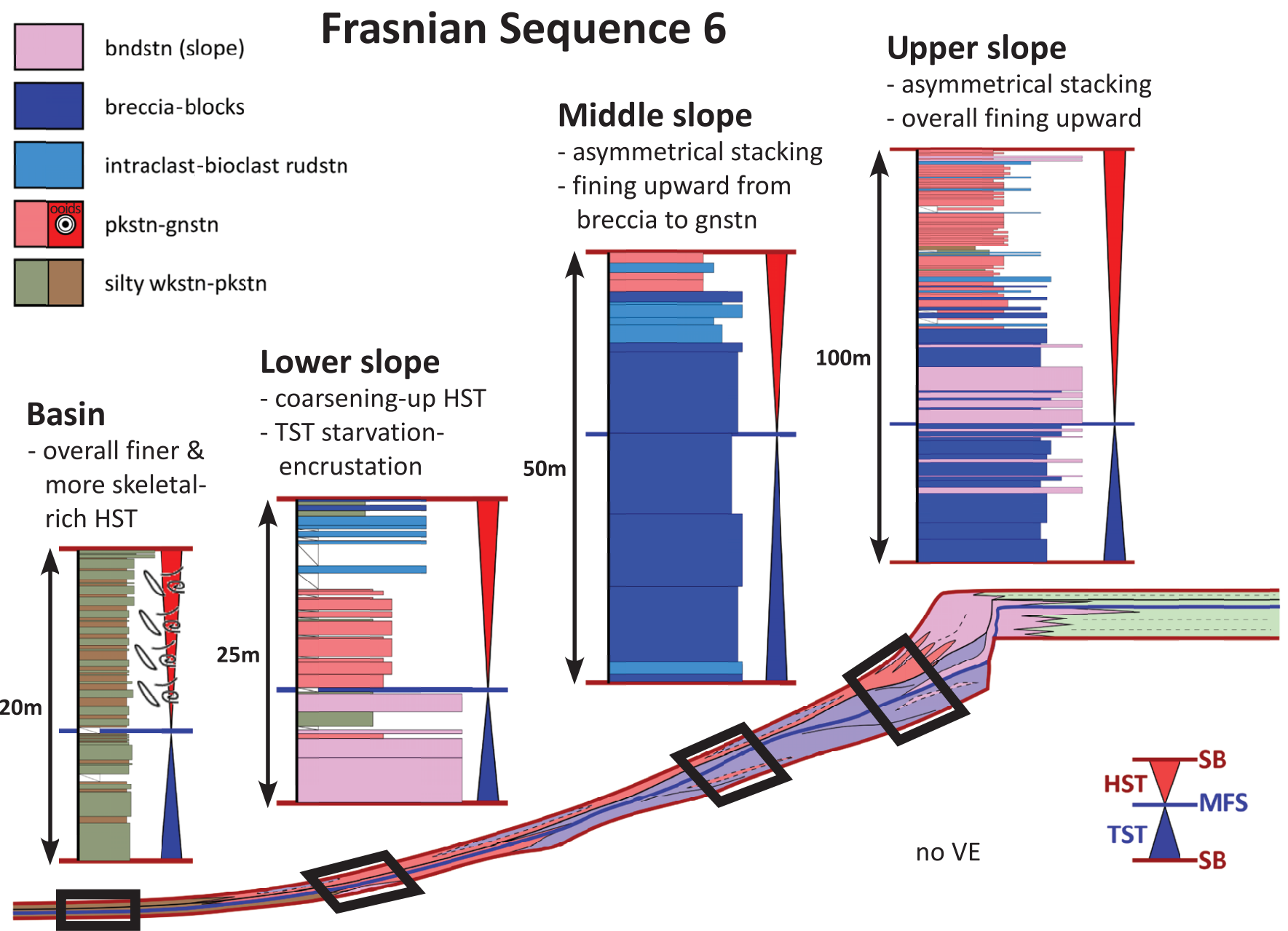

FIG. 17.-Upper Frasnian Composite Sequence 6 stacking patterns for upper-slope, middle-slope, lower-slope, and basinal environments. Color legend pertains to measured sections. See Figure 15 for supersequence context and model color scheme. See Appendices for measured sections. Upper-slope succession is from the WS measured section. Middle-slope succession is from the SO measured section. Lower-slope succession is from the VHS measured section. Basin succession is from the MR1 Winkie core. bndstn = boundstone; rudstn = rudstone; gnstn = grainstone; pkstn = packstone; wkstn $=$ wackestone.

basinward-fining pattern from debris-rich to grain-dominated to mud-dominated assemblages (Fig. 20B).

The upper slope of Sequence 1 displays rather undiagnostic stacking patterns with interbedded debris and boundstone (Fig. 21), but the middle slope exhibits a clear asymmetrical pattern with a thick grain-dominated TST and thinner, more debris-rich HST. Lower-slope stacking is also asymmetrical, but in the opposite sense, with greater debris proportions in the TST and an upward transition from grain- to mud-dominated deposits in the HST. Basinal stacking displays increased skeletal content in the HST, possibly reflecting recovery of some faunal groups subsequent to the extinction.

\section{Lower-Middle Famennian Composite Sequence 2}

Famennian Sequence 2 was strongly progradational, as it was in the heart of the supersequence HST, and was deposited long after the F-F biotic crisis, when carbonate factories presumably were functioning at full capacity (Fig. 10). The TST margin of Sequence
2 is interpreted to have an aggradational component, but it also reconstructs to have been weakly progradational, reflecting the longer-term forcing of the supersequence HST (Fig. 22A). The sustained deep microbial boundstone factory also contributed to progradation during the TST. Transgressive systems tract foreslopes, however, were overall grain dominated, suggesting a net stability of the margin, some progradation notwithstanding. The HST of Sequence 2 exhibited strong progradation of the deep microbial margin and upper slope, which resulted in episodic instability, collapse, and consequent debris tongue deposition on the slope. Thus, the foreslopes generated were mixtures of grain-dominated and debris deposits and gradually decreased basinward in the coarser particle fractions (Fig. 22B).

The stacking patterns for Sequence 2 (Fig. 23) show a uniform succession down the slope, consisting of more debris-rich HSTs yielding asymmetrical, coarsening upward vertical stacks and reflecting the changing progradational trajectories from TST to HST. Basinal stacking is less clear than is that of the slope, although rare debris is present in the HST (Fig. 13E). 


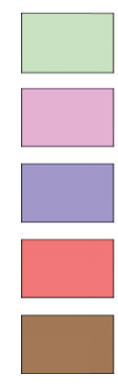

platform top

margin-slope-basin boundstone

slope-basin debris deposits

slope-basin grain-dom'd deposits

slope-basin mud-dom'd deposits

Frasnian Sequence 7

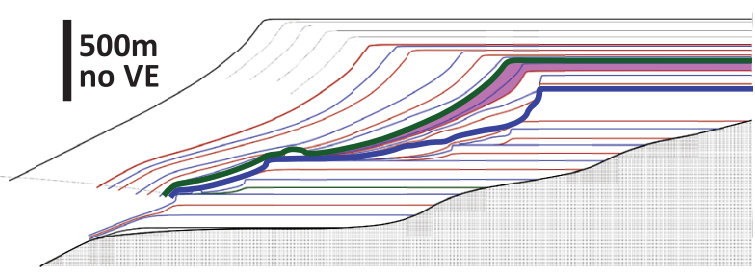

\section{$200 \mathrm{~m}$}

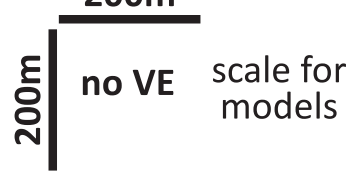

\section{B) HST}

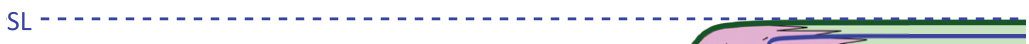

A) TST

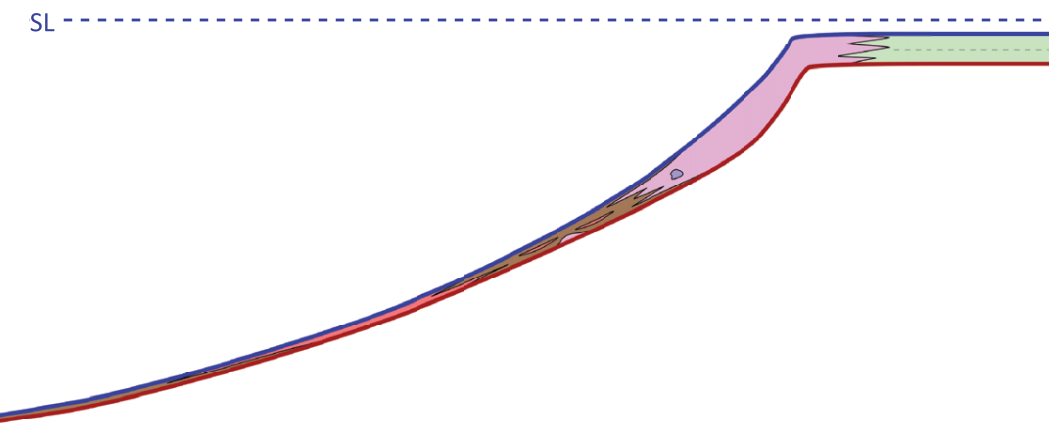

FIG. 18.- Upper Frasnian Composite Sequence 7 margin-to-slope development within the supersequence prograding HST just prior to the F-F boundary. Red lines are sequence boundaries and blue line is maximum flooding surface. In upper right inset, placement within supersequence architecture shown in purple, and blue and green lines are supersequence MFS and F-F boundary, respectively. dom'd = dominated. A) TST setting: margins aggraded and the encrusted upper-slope environment expanded significantly downslope. Upper-middleslope environments were silt dominated with coarser gully fills and equivalent to downdip, bypassed grain-dominated settings. Distal slope settings were overall poorly developed. B) HST setting: margins were progradational with deep boundstone environments and basinwardfining (debris-to-grain-dominated) foreslopes.

\section{DISCUSSION}

\section{Carbonate Margin and Slope Sequence Stratigraphic Concepts}

The complex shelf-to-basin depositional and architectural evolution recorded along the Lennard Shelf, and now described with substantially higher resolution and confidence than before, can be distilled into a succinct set of predictive concepts and associations that are broadly applicable to reefal carbonate margin and slope systems. The terms and classifications used to describe the trends below are after Playton et al. (2010). These predictive associations are particularly useful for characterization of steepsided carbonate subsurface reservoirs with seismic-scale, supersequence backstepping-to-prograding architectures. Seismic volumes can typically resolve supersequence-scale systems tracts and long-term TST vs. HST geometries, but the Lennard Shelf models 


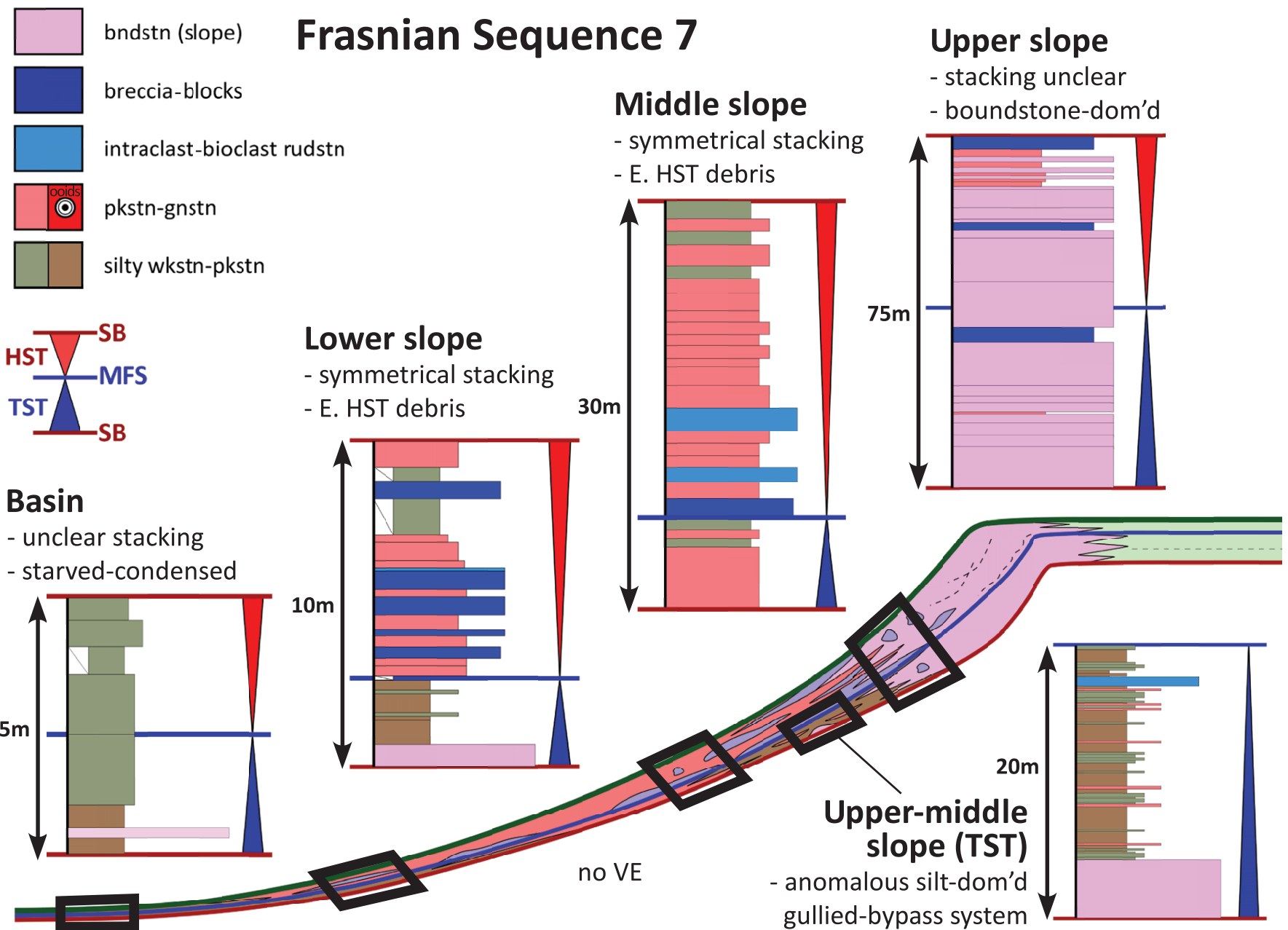

FIG. 19.- -Upper Frasnian Composite Sequence 7 stacking patterns for upper-slope, middle-slope, lower-slope, and basinal environments. Color legend pertains to measured sections. See Figure 17 for supersequence context and model color scheme. See Appendices for measured sections. Upper-slope succession is from the WV measured section. Upper-middle-slope inset succession from CF4 measured section in Playton and Kerans (2015b, their fig. 8). Middle-slope succession is from the SO measured section. Lower-slope succession is from the VHS measured section. Basin succession is from the CL measured section. dom'd = dominated; bndstn = boundstone; rudstn = rudstone; gnstn = grainstone; pkstn $=$ packstone; wkstn $=$ wackestone .

illustrate the subseismic margin and slope facies associations, proportions, architectures, and their temporal arrangements that are generally well beyond the interpretive limits of most subsurface data sets.

Margins and Slopes During Supersequence TSTs: Supersequence TSTs represent long-term high-accommodation conditions; thus, reefal margins have the tendency to backstep and aggrade. Margins often construct relief from relatively flat underlying substrates and over time outpace their own equivalent foreslope accumulations through vertical aggradation, producing an escarpment configuration, with onlapping slope strata beneath coeval reefal environments; these are termed "growth escarpments." A threshold of maximum escarpment development is reached when the slope profile is underfilled to the point at which the margin becomes susceptible to failure and collapse and generates debris deposits on the slope and in the basin. This occurs in the Late TST of the composite sequence, just prior to backstepping at the MFS (Fig. 11). Up to and after this point, margins throughout the composite sequence are stable, from either building upward instead of outward and/or through the presence of a flat underlying substrate. Thus, middle- and lower-slope stacking patterns will contain a symmetrical record, with debris deposits concentrated just beneath the composite sequence MFS and graindominated deposits bracketing the debris below and above (Figs. 12, 13A). This style of organization can be predicted at a subordinate sequence scale within a supersequence TST. Age-equivalent reefal margins of the Alberta Basin in Western Canada (e.g., Workum and Hedinger 1989, Whalen et al. 2000) can be classified as growth escarpments, yet it is difficult to compare middle-slope stacking patterns meaningfully as a result of different sequence stratigraphic criteria for interpretation of backstepping surfaces, degrees of basin fill from external input, backstepping distances, and margin declivities. However, Whalen et al. (2000) mapped tongues of debris in slope settings bracketed below and above by grain- to mud- 
platform top

margin-slope-basin boundstone

slope-basin debris deposits

slope-basin grain-dom'd deposits

slope-basin mud-dom'd deposits

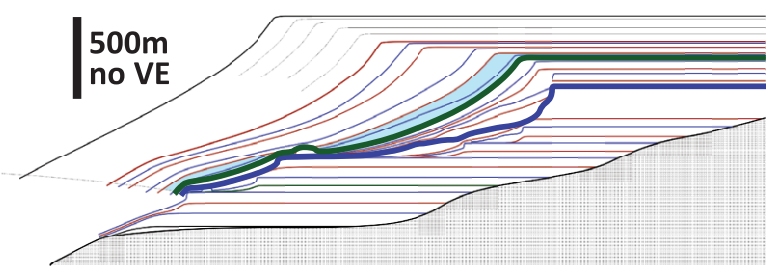

$200 m$

\section{Famennian Sequence 1}
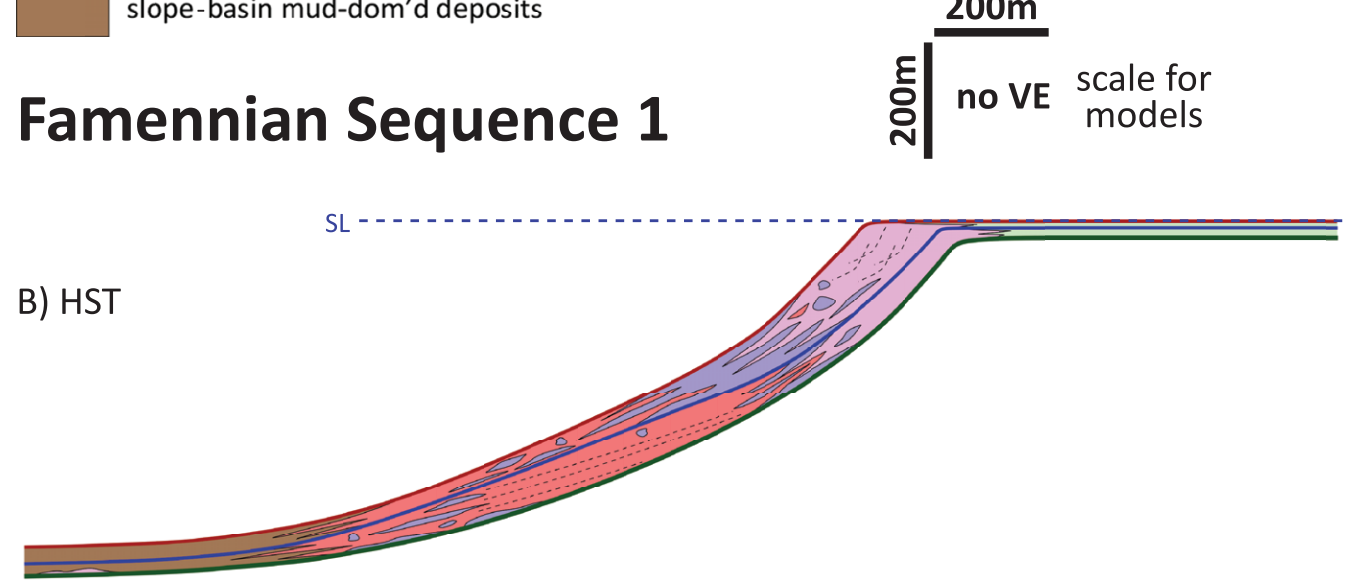

A) TST
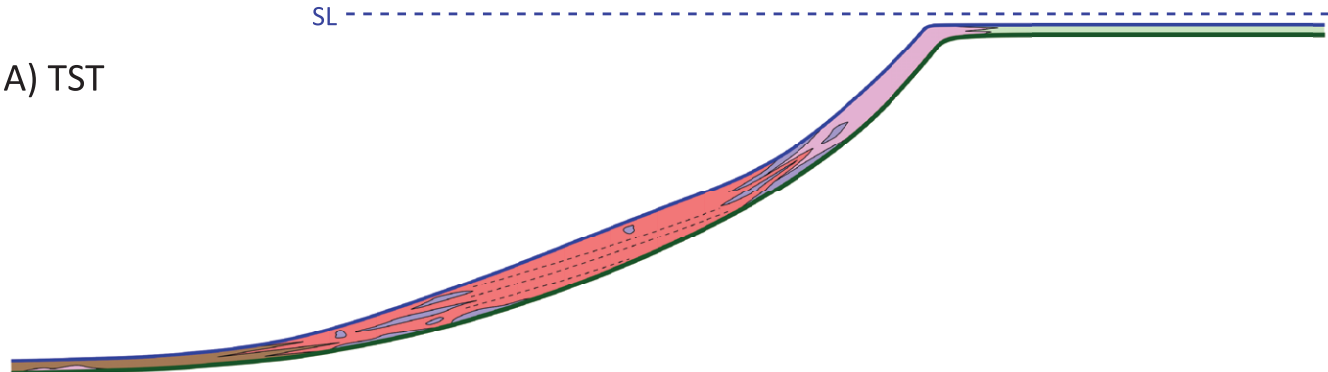

FIG. 20.- Lower Famennian Composite Sequence 1 margin-to-slope development within the supersequence prograding HST just subsequent to the F-F boundary. Red line is sequence boundary, blue line is maximum flooding surface, and green line is F-F boundary (also a sequence boundary). In upper right inset, placement within supersequence architecture shown in light blue, and blue and green lines are supersequence MFS and F-F boundary, respectively. dom'd = dominated. A) TST setting: margins were weakly progradational with a thin upper-slope boundstone veneer. Middle slopes exhibited anomalously thick stacks of oolitic grainstone (red) and debris in lower-slope settings, suggesting bypass. B) HST setting: margins were strongly progradational with deep microbial boundstone and basinward-fining (debris-tograin-dominated) foreslopes.

dominated deposits for their backstepping Sequence 3, similar to the overall vertical succession described here.

Margins and Slopes During Supersequence MFSs: Around the supersequence MFS, at the long-term transition from margin aggradation and backstepping to progradation, slope profiles are significantly underfilled and margins are highly unstable. This results in sustained collapse, the formation of erosional escarpments, and the generation of debris-dominated slopes. Only after prolonged mass wasting of the margin produced enough debris to infill the slope profile and emplace a substrate for progradation could the margin successfully advance basinward and evolve an accretionary, interfingering configuration. Thus, around the supersequence MFS, debris- dominated slopes are likely over one or two subordinate (i.e., thirdorder) sequences, and margins will predictably evolve from erosional escarpments to accretionary configurations (Figs. 14, 16). Internal stacking patterns on the slope will be somewhat indistinct, precluding subdivision into subordinate sequences. This is due to anomalously thick, amalgamated successions of debris, but thin grain-dominated intervals likely mark the onset and terminus of the slope readjustment and infilling period (i.e., the base of Frasnian Sequence 5 and cap of Frasnian Sequence 6; Figs. 15, 17). This pattern of collapse and debris-dominated slope development around supersequence MFSs is observed in multiple other outcrop and subsurface data sets, including the highly comparable, age-equivalent western Canadian system and Late Paleozoic isolated carbonate platforms of the Pricaspian Basin in 


\section{Famennian Sequence 1}

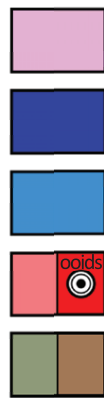

bndstn (slope)

breccia-blocks

intraclast-bioclast rudstn

pkstn-gnstn

silty wkstn-pkstn

\section{Lower slope}

- asymmetrical stacking - debris-rich TST
Middle slope

- asymmetrical stacking

- debris-rich HST

\section{Basin}

- skeletal-rich HST

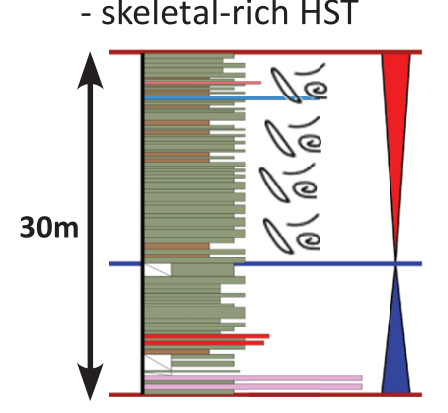

$35 \mathrm{~m}$
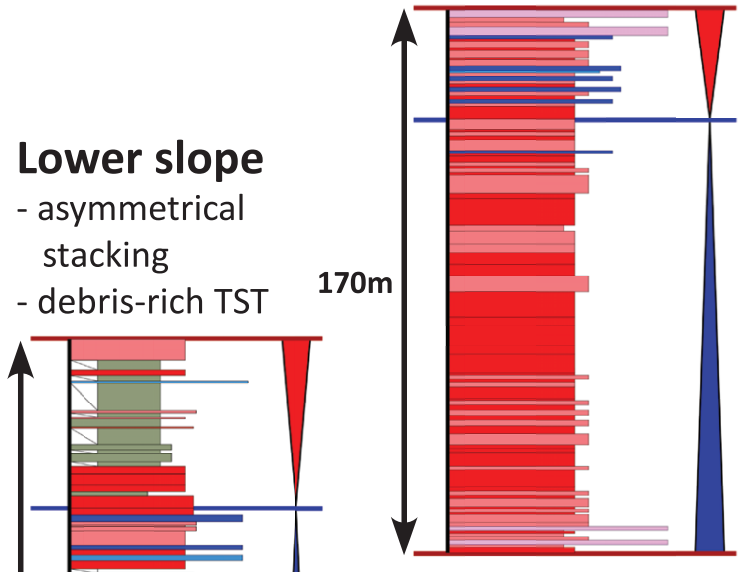

Upper slope

- stacking unclear

- debris-dom'd with boundstone tongues
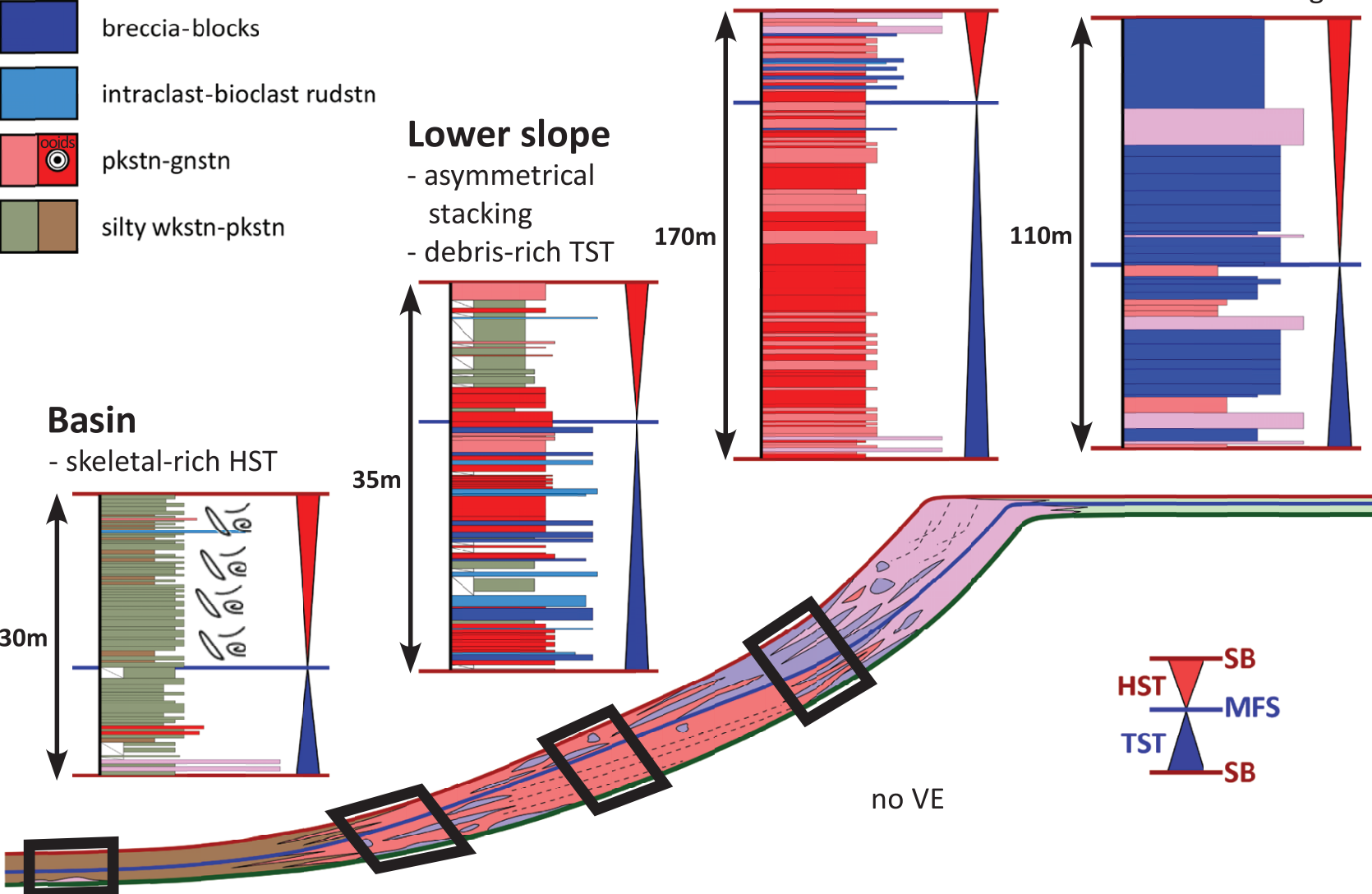

Fig. 21.-Lower Famennian Composite Sequence 1 stacking patterns for upper-slope, middle-slope, lower-slope, and basinal environments. Lower green line is F-F boundary (also a sequence boundary). Color legend pertains to measured sections. See Figure 19 for supersequence context and model color scheme. See Appendices for measured sections. Upper-slope succession is from the WV measured section. Middleslope succession is from the SO measured section. Lower-slope succession is from the VHS measured section. Basin succession is from the CL measured section. dom'd $=$ dominated; bndstn = boundstone; rudstn = rudstone; gnstn = grainstone; pkstn $=$ packstone; wkstn $=$ wackestone.

western Kazakhstan (see Discussion and references in Playton and Kerans 2015a).

Margins and Slopes During Supersequence HSTs: During the supersequence HST, the overall setting is accommodation limited and margins are consequently progradational. This repeated tendency for margins to strongly build outward at subhorizontal trajectories results in frequent local and episodic failure. These local points of oversteepening quickly heal, re-accrete, and eventually fail again. This process is repeated continuously at numerous points along strike at any given time during progradation, resulting in debris tongue deposition on the slope. Within a composite-scale sequence, the HSTs are more strongly progradational compared to the TSTs; hence, HST margins fail more often and produce greater proportions of debris on the slope than do TST margins (Fig. 22). It follows that the composite sequence middle-lower-slope stacking patterns will reflect this with greater debris proportions in the HSTs, producing a coarsening upward, asymmetrical succession (Fig. 23). Moreover, supersequence debris accumulations will have a similar overall organization, with greater debris proportions in the prograding HST sequences compared to that of the TST backstepping sequences. These patterns of TST vs. HST debris proportions, both at supersequence and subordinate sequence scales, are not widely documented in other data sets but were briefly overviewed in Playton et al. (2010) and discussed further in Playton and Kerans (2015b).

Margins and Slopes During Global Biotic Crises: Global biological and ecological stress intervals will have particular characteristics and nuances throughout geological history. However, with regard to carbonates in a broad sense, periods of biotic stress are reflected in the changing of entire carbonate factories and adverse effects on certain components. As a consequence, elevated microbial activity is common during these times, indicating rapid opportunistic filling of niches held by organisms in decline. Moreover, margins may 
platform top

margin-slope-basin boundstone

slope-basin debris deposits

slope-basin grain-dom'd deposits

slope-basin mud-dom'd deposits

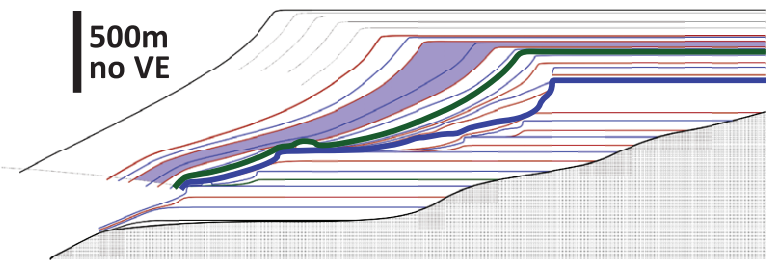

$200 \mathrm{~m}$

\section{Famennian Sequence 2

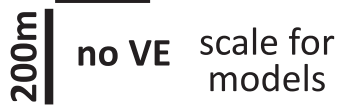

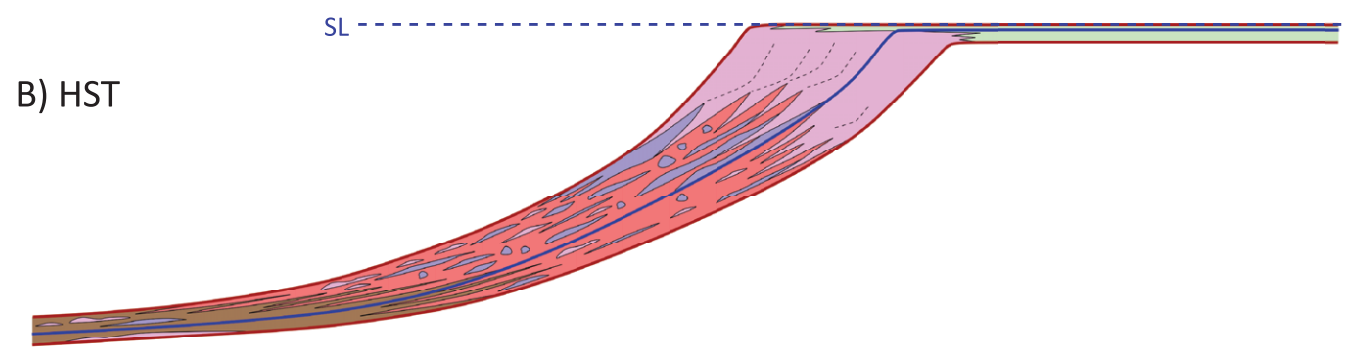

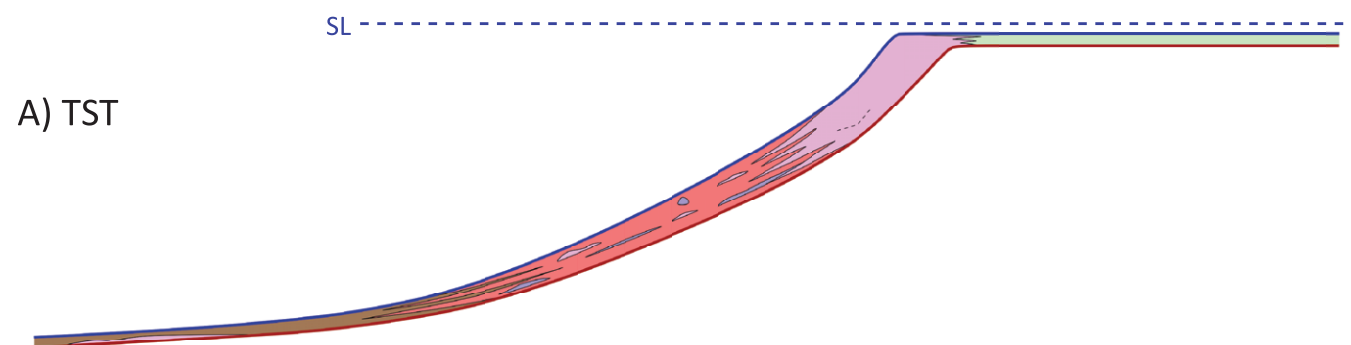

FIG. 22.-Lower-Middle Famennian Composite Sequence 2 margin-to-slope development within the supersequence HST when margins were strongly progradational. Red lines are sequence boundaries and blue line is maximum flooding surface. In upper right inset, placement within supersequence architecture shown in blue, and blue and green lines are supersequence MFS and F-F boundary, respectively. dom'd = dominated. A) TST setting: margins were weakly progradational and with deep boundstone upper slopes and grain-dominated foreslopes. B) HST setting: margins were strongly progradational with deep boundstone upper slopes and mixed debris- and grain-dominated foreslopes.

abruptly shift from shallow euphotic configurations to deeper oligophotic styles. In terms of slope development, anomalous styles or highly partitioned stratigraphic packaging may result from pauses or transformations of the typical sources of downslope sediment (Figs. $18,20)$.

In terms of stacking patterns or predictive trends (Figs. 19, 21), three likely phenomena should be considered based on observations from the Lennard Shelf data set (see Playton and Kerans [2015b] for further discussion): (1) abrupt starved slope intervals indicating a temporary hiatus in production and downslope shedding from the usual carbonate factories (e.g., the siltdominated gullied slope system in the TST of Frasnian Sequence 7); (2) signs of elevated microbial activity in any setting (e.g., downslope expansion of upper-slope microbial boundstone starting in Frasnian Sequence 7; Fig. 13D); and (3) the dominance of a single sediment source contributing to slope deposits, often indicating the first carbonate factory to recover postextinction while others remain in stress (e.g., ooid-dominated slopes in the
TST of Famennian Sequence 1). While these factors can certainly affect margin-to-slope architecture, the influence of accommodation drivers will persist and likely dominate geometric development during biotic crises. Thus, the key indicators of extinction intervals on carbonate slopes are typically rather rapid or uncharacteristic compositional variations that depart from more commonly observed stacking patterns. George and Chow (2002) and Playford et al. (2009) looked at multiple measured sections around the F-F boundary in middle- to lower-slope settings along the Lennard Shelf and repeatedly observed evidence for reduced carbonate factory production and resultant starved slope conditions at the extinction surface. These findings indicate that a distinctive signature of paused carbonate factories is likely to mark the actual boundary on the slope and may be equivalent to an unconformity or disconformity on the platform-top. Our data set additionally proposes recognizable characteristics that define the extinction interval - the onset of biotic stress and recovery to a healthy, productive carbonate system. 


\section{Famennian Sequence 2}

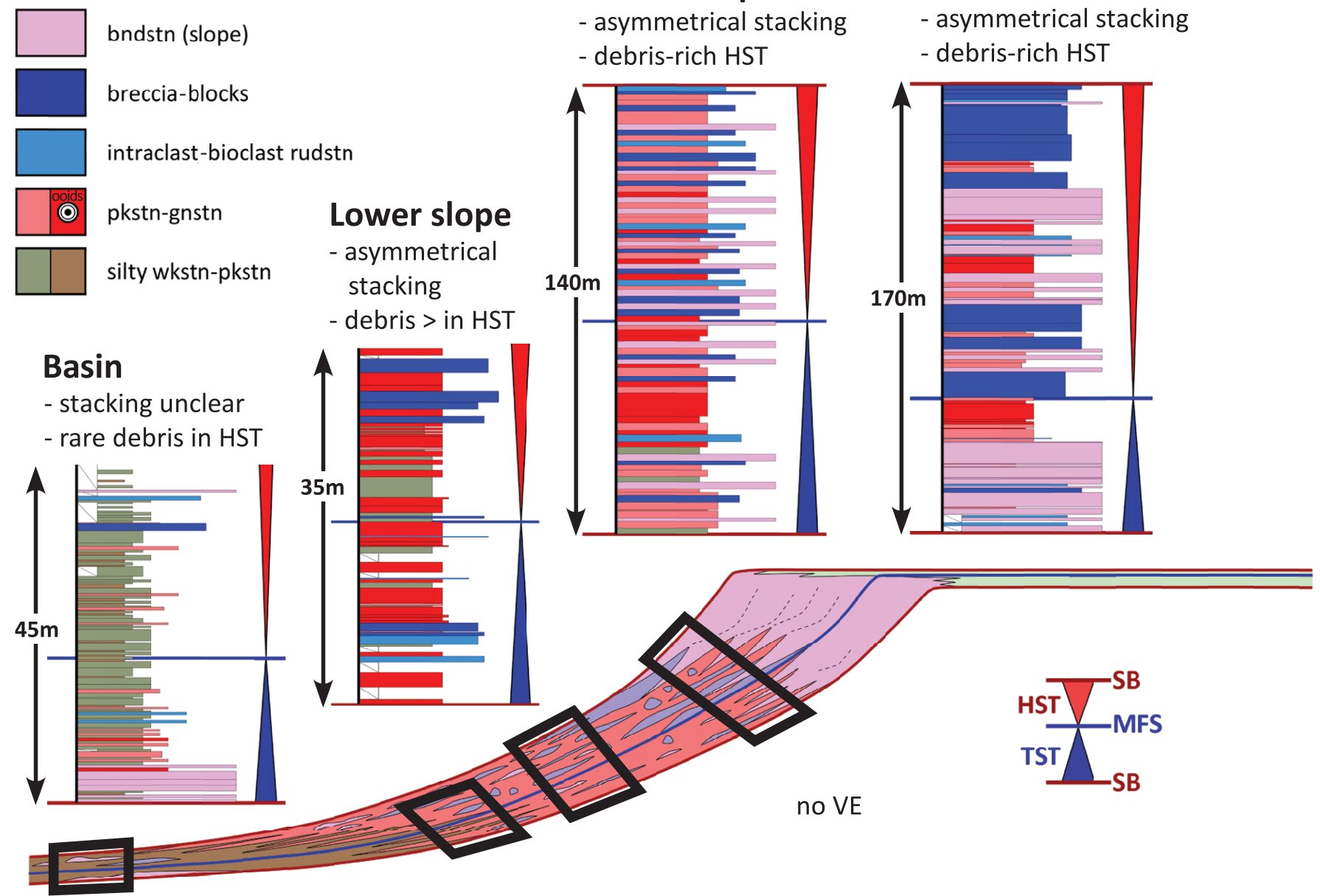

Fig. 23.-Lower-Middle Famennian Composite Sequence 2 stacking patterns for upper-slope, middle-slope, lower-slope, and basinal environments. Color legend pertains to measured sections. See Figure 21 for supersequence context and model color scheme. See Appendices for measured sections. Upper-slope succession is from the WV measured section. Middle-slope succession is from the SO measured section. Lower-slope succession is from the VHS measured section. Basin succession is from the CL measured section. bndstn = boundstone; rudstn $=$ rudstone; gnstn $=$ grainstone; pkstn $=$ packstone; wkstn $=$ wackestone .

\section{Comparison With the Work of Playton and Kerans (2015a, 2015b)}

Growth Escarpments: Growth escarpments represent a margin and slope evolution that is controlled by high accommodation conditions during long-term TSTs. Playton et al. (2010) first proposed the concept of growth escarpments, dominantly based on Lennard Shelf data, and Playton and Kerans (2015a; their figs. 3, 5-9) describe their architectures, compositions, and controls in detail. This study largely corroborates these previous findings in terms of the systems tract interpretations, timing of reefal margin failure, and nature of the weakly prograding HSTs. The PGH measured section and the HD14 core (Fig. 1; Table 1; Appendices 9, 14) exhibit (1) upward-deepening outer platform to reef-flat facies successions, with (2) overlying margin-to-slope deposits that indicate progradation through upwardshallowing facies successions and/or an outcrop expression of basinward margin advance. This stacking respectively indicates TST conditions with aggrading margins followed by MFS backstepping and subsequent weak HST progradation, which agrees with the sequence stratigraphic interpretation of Playton and Kerans (2015a, 2015b). The middle-slope equivalent to this type of succession can be observed in the SO measured section (Sequence 4, but relevant for older backstepping sequences; Fig. 12) with (1) grain-dominated slopes during the TST reflecting stable aggradational margins; (2) slope debris deposits just prior to backstepping in the Late TST indicating a sensitivity to failure triggers during peak escarpment growth and collapse; and (3) overlying grain-dominated deposits recording the weak progradation of a stable margin with a solid underlying foundation. Playton and Kerans (2015a; their fig. 7D) observed a margin reentrant, generated from large-scale failure, equivalent to the latest stages of escarpment growth immediately before an interpreted backstepping event. This supports the Late TST collapse that we also propose here and represents a mechanism and timing for margin failure not discussed in Playton et al. (2010). 
Timing of Collapse Around the Supersequence MFS: The findings outlined in both Playton and Kerans (2015a; their figs. 10, $12,13)$ and our study soundly document the dominant margin failure process and consequent debris-dominated slope development around the supersequence MFS, as slope profiles adjust during the change from aggradation to progradation (Figs. 14-17). Playton and Kerans (2015a) suggest that most debris shedding is concentrated during the HSTs of the composite sequences that bracket the turnaround and that TSTs represent phases of stability characterized by either grain shedding or microbial encrustation of collapsed margins. However, this study finds that once slope adjustment has commenced, debris shedding continues without interruption, regardless of systems tract, until the profile has sufficiently infilled to support progradation. Specifically, we observe margin failure throughout all of Sequences 5 and 6, with the exception of the Earliest TST of Sequence 5 and the Latest HST of Sequence 6 (Figs. 15, 17). While the mapping of Playton and Kerans (2015a) is not affected by these findings, it should be recognized that much of the slope debris during this period also originates from the TST margins of Sequences 5 and 6 . This indicates that placement of the supersequence MFS and subordinate sequence MFSs during this phase should be within the thick successions of debris on the slope, rather than at the bases. Furthermore, the microbially encrusted collapse scarp discussed in Playton and Kerans (2015a) may not be as sequence-stratigraphically significant as proposed. Instead, these encrustations may simply be locally preserved accumulations reflecting the alternating collapse and re-healing process that occurs throughout all systems tracts. The base of the microbially encrusted veneer present at the Classic Face in Windjana Gorge (Playton and Kerans 2015a, after Playford et al. 2009) defines the base of Sequence 6 in that particular margin location; however, further downslope the microbial accumulation may not coincide with the sequence boundary. More substantially, these observations point to a failure mechanism that results in repeated, high-frequency collapses along a vertical scarp during periods of sustained aggradation-a mechanism not discussed in Playton et al. (2010).

Recovery Period After the F-F Boundary: The characterization in this study of the sequence leading up to the F-F boundary (Frasnian Sequence 7; Figs. 18, 19) conforms to the descriptions of Playton and Kerans (2015b). These and our current observations effectively capture margin and slope development just prior to the significant event (i.e., silt-dominated TST settings and downslope microbial boundstone expansion). Herein, Famennian Sequence 1 is the sequence immediately after the F-F boundary, representing the postextinction recovery period (Figs. 20, 21), and is analogous in terms of timing to the "Lowermost Famennian" of Playton and Kerans (2015b). However, the two depositional models vary somewhat in terms of the importance placed on certain processes and resulting facies proportions (see fig. $3 \mathrm{C}$ in Playton and Kerans 2015b). In this study, the middle- and lower-slope transects for Famennian Sequence 1 represent an open ocean-facing setting on the seaward side of an outboard structure and within a large $(>50 \mathrm{~km}$ across) embayment in the Lennard Shelf, respectively (Fig. 1, SO and VHS sections, respectively). These sections indicate copious bypass of oolitic grain-dominated material and some debris immediately following the F-F boundary, suggesting ooid shoals were among the first carbonate factories to recover and prosper. The upper-slope control transect (WV section, Fig. 1) for this study is located at the entrance of an elongate margin reentrant that, although within a paleogeographic embayment, likely had a direct connection with the open ocean. This section exhibits a debris-rich setting with intercalations of microbial boundstone, indicating the typical interfingering at the upper-middle-slope transition. This constrains the water depth of the encrusted upper-slope environment down to approximately $200 \mathrm{~m}$, comparable to that of the preceding sequence,
Frasnian Sequence 7 (Fig. 18). The model for the upper- and middleslope settings of the Lowermost Famennian of Playton and Kerans (2015b) was largely derived from exposures in Windjana Gorge proper, in a highly complex reentrant-promontory configuration with a depocenter somewhat sheltered from the open ocean (see their fig. 5). They describe the microbial boundstone factory expanding downslope beyond the relict depth of the previous Frasnian Sequence 7 and encroaching into apparently middle-slope environments. Moreover, a distinctive characteristic of the Lowermost Famennian is the paucity of platform-derived material in the middle slope, including oolitic grain-dominated deposits.

These disparities in platform-derived contribution and the degree of downslope microbial encrustation postdating the F-F boundary observed in the two data sets can be attributed to variability associated with different paleogeographic settings. The extraordinary amount of oolitic accumulation recorded in the middle slopes at the $\mathrm{SO}$ section is likely related to its position on the seaward edge of a somewhatisolated carbonate island. A similar pattern holds for the VHS section as a result of its location within a well-circulated mega-embayment. The upper-slope microbial boundstone factory was already fully developed in Frasnian Sequence 7 and was in equilibrium with the other slope contributors and thus does not appear to expand further in this study. Conversely, the complex paleogeographic setting of Windjana Gorge is here interpreted to have had an impact on the recovery of platform-top factories, ooid shoals included, explaining the Lowermost Famennian observations of Playton and Kerans (2015b). The delayed establishment of shallow water factories coincided with an elevation in microbial encrustation and resultant downslope expansion, suggestive of the opportunistic behavior of microbial communities. Furthermore, the likely poorer-marine circulation at Windjana Gorge may have itself been more favorable for microbial activity. The overall themes of the post-F-F recovery period still hold across both data sets (i.e., struggling and/or dominant single factories, extensive microbial activity), but the contrasts discussed here underscore the potential variability generated as a result of paleogeography and other controls on oceanographic processes, even during global phenomena.

Hierarchical Trends in Middle-Slope Debris Proportions: In this study, we observe a hierarchical pattern in middle-slope debris proportions, with greater abundances in supersequence and composite sequence HSTs when compared to their counterpart TSTs (Figs. 9, 10, $22,23)$. This again is attributed to a greater propensity for margin instability and local collapse from the outward-extending trajectories inherent to progradational phases, and this association appears to hold true at different temporal scales. Playton and Kerans (2015b) interpret the Famennian middle slopes in terms of high-frequency sequences, with debris-dominated LSTs, silt-dominated TSTs, and graindominated HSTs (their figs. 9, 13, 22C). Their model for LST collapse entails slight downstepping of the microbial margin and upper slope during platform-top emergence, resulting in a strong offlapping geometry and extreme localized instability. Data from this study suggest that this configuration and consequential process of failure are more common in composite-scale HSTs. They also indicate that a lower-frequency signal can be extracted from the detailed mapping of Playton and Kerans (2015b) through documentation of debris deposit proportions within their high-frequency sequence stacking. Moreover, these observations imply that a hierarchical sequence stratigraphic expression exists in carbonate slope deposits that is similar to the numerous well-documented data sets in carbonate platform-top settings (e.g., Goldhammer et al. 1990, Kerans and Fitchen 1995, Tinker 1998); in these cases, the expression is best developed in middle-slope settings, where the suite of diagnostic facies are present, debris deposits being a critical indicator facies. As observed here, composite-sequence-scale accommodation conditions 
are linked to the development, and thus likelihood for collapse, of upper-slope-centered, microbial boundstone margin wedges during high-frequency LSTs. Perhaps these LST accumulations are poorly developed during composite-scale TSTs because of lesser degrees of exposure and downstepping.

\section{Margin Failure Timing and Mechanisms}

Numerous studies have commented on the timing and triggering mechanisms for brittle failure of early-lithified, reefal carbonate margins (e.g., Cook et al. 1972, Cook and Mullins 1983), and a range of intrinsic and extrinsic controls have been proposed. Playton et al (2010) provide classifications for collapse scale and frequency and generalize that margin failure is more likely during long-term progradation vs. aggradation and backstepping and is highly concentrated around long-term transitions from aggradation to progradation (supersequence-scale MFSs). Playton and Kerans (2015a, 2015b) corroborate these statements with Lennard Shelf data and additionally interpret collapse to occur during the high-frequency LSTs within lower-frequency progradational successions. Our data set allows further investigation of the timing and mechanisms for reefal margin collapse using the added constraints of a hierarchical, slope sequence stratigraphic framework.

Collapse During the TST: This study and that of Playton and Kerans (2015a) observed that escarpment margins within the overall backstepping supersequence TST become unstable and fail just prior to backstepping events when escarpment walls developed the greatest relief. On the composite-sequence-scale, the timing of these failures is in the Late TST, immediately before backstepping at the MFS and coeval with vertical margin and platform-top aggradation (Fig. 11) This study and that of Playton and Kerans (2015a) also document a period of sustained failure bracketing the supersequence MFS as margins and slope profiles adjusted across the aggradation-toprogradation turnaround and over the span of two composite sequences (Frasnian Sequences 5 and 6). Playton and Kerans (2015a) interpreted that collapse occurred only in the compositescale HSTs of Sequences 5 and 6, owing to margin outbuilding over unstable or inadequate substrates. However, this study proposes failure also in the TSTs of Sequences 5 and 6, during vertical aggradation of the margin and platform-top (Figs. 15, 17).

Thus, this study recognizes multiple instances of compositesequence-scale TST failure of vertically aggrading escarpment margins, a timing that is not discussed in Playton et al. (2010). In fact, their study (Playton et al. 2010) considered aggradational trajectories unlikely to favor collapse. A highly constrained sequence stratigraphic platform-toslope correlation allows examination of the mechanism behind the observed TST failure (Fig. 24). Platform-top TST stacking patterns that are equivalent to debris deposits on the slope display higher-frequency cycle sets within overall aggradational successions. The cycle sets consist of deepening upward cycles passing into shallowing upward cycles and thus represent small-scale backstepping to prograding alternations. As the escarpment margins approached great relief and declivity through aggradation, they became highly susceptible to collapse. We interpret high-frequency progradational pulses at the margin, recorded within the cycle set stacking on the platform, as the cause of TST collapse. Small outbuilding events at the escarpment edge are adequate to initiate medium- to large-scale failure along an already highly unstable margin profile. This configuration appears to develop distinctly in the Late TSTs of composite sequences within supersequence TSTs and persists across entire composite-scale TSTs across the supersequence MFS.

Collapse During the HST: Instability and failure are common during times of long-term progradation due to overall outbuilding margin trajectories over poorly developed or nonexistent substrates This was proposed as one of the more likely mechanisms by Playton et al. (2010) and was discussed at length in Playton and Kerans (2015b). Playton and Kerans (2015b) interpret debris deposits within the supersequence HST to represent the LSTs of internal high-frequency sequences. These deposits coincided with margin- and upper-slopecentered wedges of microbial boundstone that developed while the platform-top was largely exposed. These wedges accrete subhorizontally in a basinward direction and become highly prone to local collapse along strike. High-frequency silt-dominated TST deposits and grain-dominated HST deposits follow and bury the LST debris to construct a clinothem, the fundamental building block of a progradational slope system.

This study was able to establish a composite-sequence-scale stratigraphy within the Famennian, providing an internal framework for the supersequence HST and enabling investigation of the distribution of high-frequency debris deposits within the sequence hierarchy. We find that debris deposits are more concentrated in composite sequence HSTs than in TSTs (Fig. 23). This suggests that either the development of high-frequency LST margin wedges or their collapse potential varies depending on position within the lowerfrequency setting. It is conceivable that wedge trajectories were likely closer to horizontal (or even downstepping) during composite HSTs vs. TSTs and are thus more prone to failure. It is also possible that the balance of the rate of margin outbuilding relative to the accumulation rate of detrital sediment along the slope profile changed, whether within a composite HST or TST, in turn influencing collapse through the availability of underlying substrate. Further work is required to fully understand this process, but it is important to recognize the hierarchical organization we observe in margin failure patterns within the longerterm progradational succession and that failure in these settings is induced via mechanisms that force an already-outbuilding margin at the angle of repose to periodically accrete beyond the angle of yield.

\section{Middle-Slope Stacking Patterns}

Stacking pattern analysis for carbonate platform-top settings has been widely applied for decades and allows for two-dimensional predictions away from one-dimensional successions of facies (e.g. Goldhammer et al. 1990, 1993; Kerans and Nance 1991; Kerans and Fitchen 1995; Read 1995; Kerans and Tinker 1997; Lehrmann and Goldhammer 1999). Making possible this methodology is the sensitive response of shallow water carbonate production and accumulation to accommodation changes and the assumption that the stratigraphic record left behind is largely complete. Kerans and Tinker (1997) provide an excellent workflow and set of criteria with which to interpret sequences and systems tracts from one-dimensional stacks of carbonate shallow water deposits, including the usage of facies proportions, cycle thickness, indicator facies, facies offset, and exposure indices to interpret the accommodation history and migration of facies belts over time in a particular system.

In carbonate slope environments, however, (1) the assumptions that sediments are sensitive to and will likely infill accommodation do not apply; (2) exposure indicators are nonexistent in most positions along high-relief slope profiles; (3) thickness patterns of sediment packages are generally meaningless, given the degree of strike variability commonly observed; and (4) facies offset is often undiagnostic, as highly varying deposit types are frequently juxtaposed vertically (as well as laterally). These reasons have led to the underdevelopment of carbonate slope stacking pattern criteria; however, our data set provides sufficient control to establish generalized rules at the composite and supersequence scales. We find that the proportions of debris-, grain-, and mud-dominated deposits are useful for interpreting carbonate slope vertical successions. Middle-slope, and to a lesser extent lower-slope, settings provide the best information, as adequate representations of the 


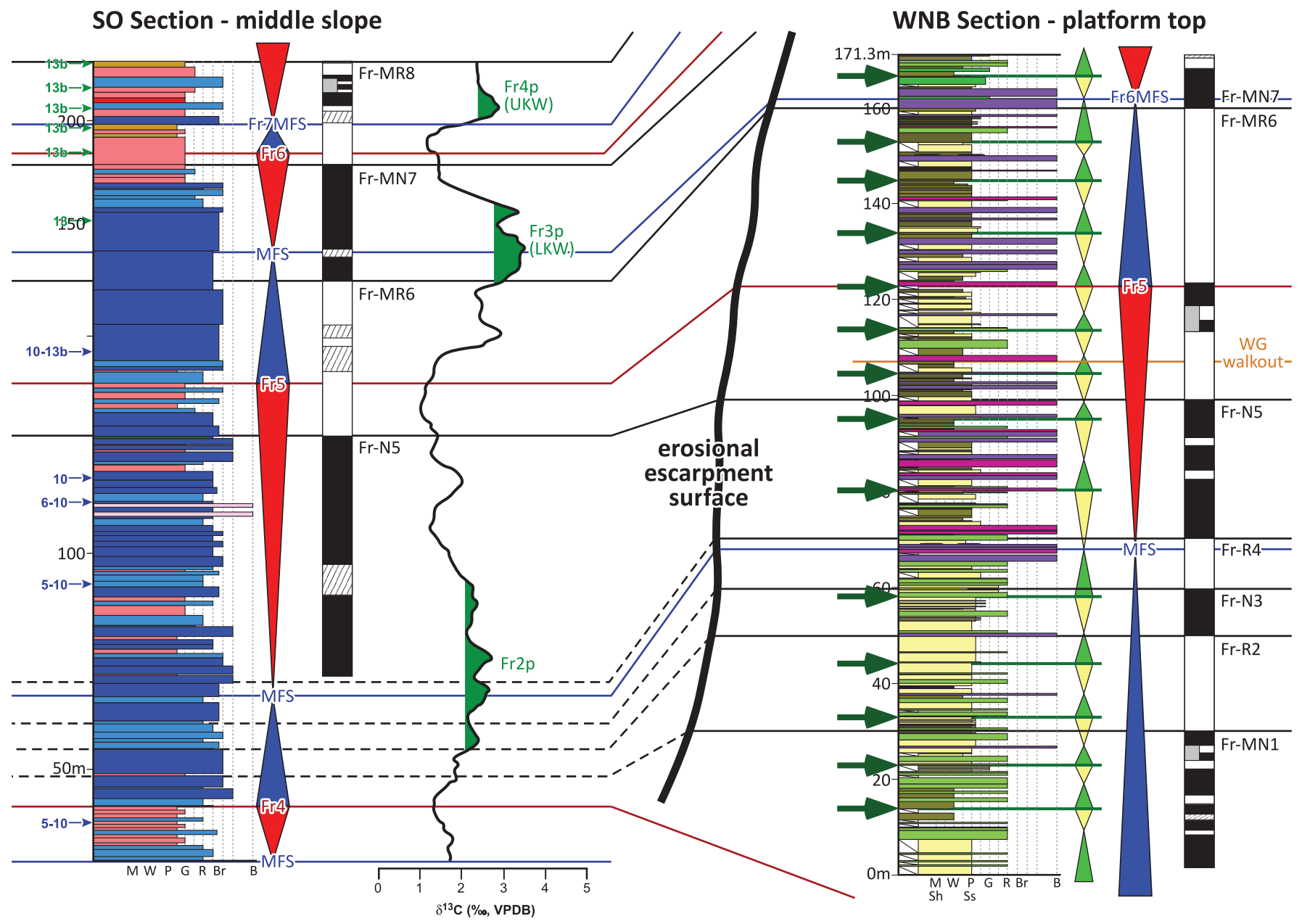

FIG. 24.- SO and WNB measured sections with platform-top to middle-slope correlations and highlighting progradational pulses at cycle set scale (dark green arrows along WNB) during overall aggradational succession. Progradational pulses in composite sequence TSTs are here interpreted as the mechanism for margin failure during platform and margin aggradation, resulting in stacked debris deposits on the slope during the TST. Facies and correlation control (including conodont picks, paleomagnetic polarity reversals, and carbon isotopes) shown with composite sequence and cycle set interpretations (red-blue and yellow-green triangles, respectively). See Appendix 1 for detailed legend. See Figures 8 and 9 for chronostratigraphic information. See Appendices 3 and 6 for detailed measured section data.

key deposit types are generally present. The three families of deposit types (debris-, grain-, and mud-dominated; see Playton et al. 2010) are all meaningful in terms of source carbonate factory and process, though we find debris deposits to be the most effective as indicator facies, as they tend to occur at distinctive positions within the hierarchy of sequences and form the basis for the vertical patterns we observe in slope strata. We here propose three fundamental middle-slope stacking patterns, organized by position within the supersequence and relevant for steep reefal margin systems (Fig. 25).

Composite Sequence Succession Within the Supersequence TST: These successions are symmetrical, with debris deposit cores and bracketed above and below with grain-dominated deposits (Fig. $25 \mathrm{~A})$. The proportions of grain-dominated deposits are at least twice that of the debris; however, this ratio can vary along strike. Thicknesses are generally less than $100 \mathrm{~m}$, as these slope accumulations are onlapping wedges (vs. laterally extensive prograding clinothem systems). These successions represent growth escarp- ment evolution and composite sequence development within the supersequence TST, in which margins (1) aggrade stably in the Early TST, producing grain-dominated slopes, (2) surpass a threshold of instability in the Late TST, resulting in collapse and slope debris deposition, (3) backstep at the MFS, and (4) weakly prograde in the HST while maintaining stability, thus feeding grain-dominated slopes.

Succession Across the Supersequence MFS: These symmetrical successions consist of thick and amalgamated stacks of debris deposits with significantly thinner grain-dominated bases and caps and are conspicuously debris-rich intervals within extensive slope successions (Fig. 25B). The overall proportions heavily favor debris deposits, with thicknesses potentially well over $100 \mathrm{~m}$. These successions indicate the period of prolonged and sustained margin mass wasting as the slope profile readjusts and is gradually infilled with debris. This characteristically occurs at the transition from long-term aggradation and backstepping to progradation around the supersequence MFS. Placement of the supersequence MFS is likely in the lower half of the debris 


\section{Middle Slope Stacking Patterns - accommodation signals}

A) composite sequence within supersequence TST

- symmetrical, debris-cored \& bracketed $\mathrm{w} /$ grain-dom'd deposits - approx. 67\% grain-dom'd deposits, $33 \%$ debris deposits

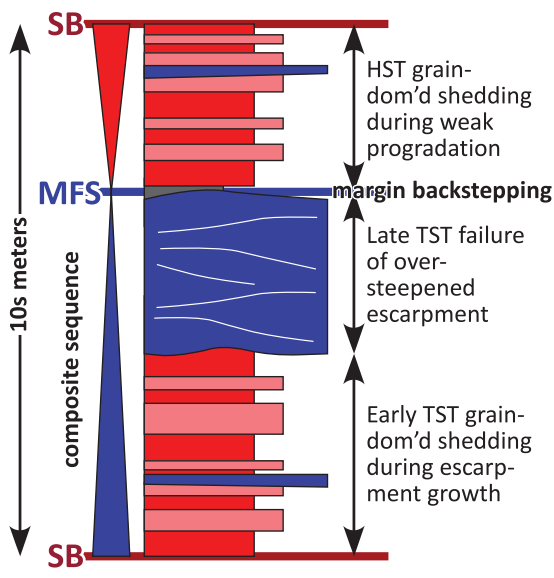

B) across supersequence MFS

- symmetrical, debris-dom'd w/ grain-dom'd cap \& base

- approx. $80 \%$ debris deposits, $20 \%$ grain-dom'd deposits

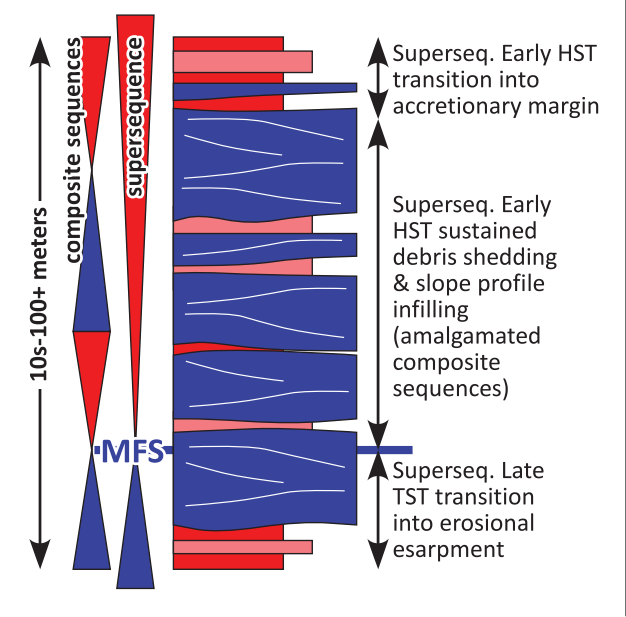

C) composite sequence within supersequence HST

- asymmetrical, upward increase in debris deposits

- $<10 \%$ debris deposits in TST, 25-50\% debris deposits in HST

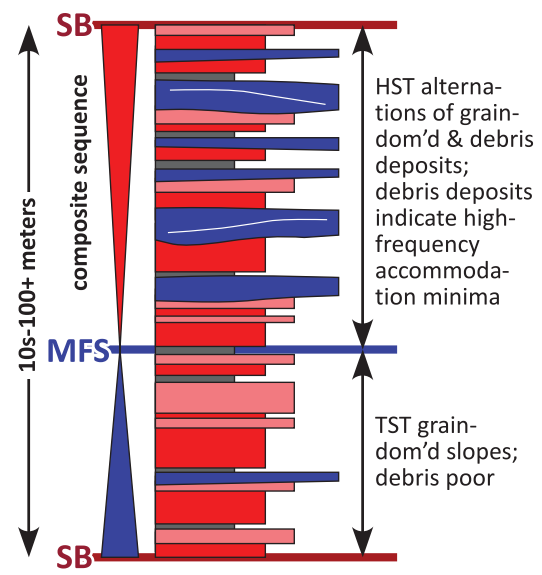

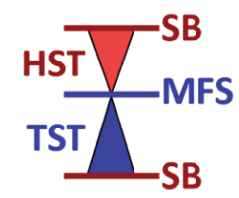

debris deposits

grain-dom'd deposits

mud-dom'd deposits

FIG. 25.-Idealized vertical facies successions in a middle-slope setting showing composite sequence stacking patterns at various points within a supersequence. dom'd = dominated. A) Composite sequence stacking within a supersequence TST. Starved slope drape recording margin backstepping at the MFS may be poorly preserved. B) Stacking across long-term transition from aggradation to progradation at the supersequence MFS. Composite sequences are amalgamated during erosional escarpment phase; thus, exact placements of systems tracts shown are somewhat arbitrary. Supersequence MFS is positioned low within the debris succession, as the majority of slope infilling occurs in the supersequence Early HST. C) Composite sequence stacking within a supersequence HST. Occurrences of debris represent high-frequency LSTs (see Playton and Kerans 2015b).

succession, as the majority of failure and slope infilling occurs in the supersequence Early HST, when the system is unable to prograde. The grain-dominated base of the succession reflects the final stages before the margin shifts to an erosional escarpment, and, similarly, the graindominated cap marks the development of accretionary margins after regrading of the slope profile to the angle of repose. We observe here that this overall succession occurs over the span of two composite sequences (Frasnian Sequences 5 and 6), but definition of the composite-scale systems tracts and bounding surfaces is difficult because of the amalgamated nature of the debris succession.

Composite Sequence Succession Within the Supersequence HST: These slope successions show an upward increase in debris deposits, producing a coarsening upward, asymmetrical profile (Fig. $25 \mathrm{C})$. Debris-poor $(<10 \%)$ lower portions represent composite-scale TSTs and are generally grain-dominated. Debris-rich (25-50\%) upper portions represent composite-scale HSTs and show alternations between grain-dominated and debris deposits with variable preservation of mud-dominated deposits. Overall stratigraphic thicknesses can be greater than $100 \mathrm{~m}$, as these are transects of prograding clinothems.
These successions are found within supersequence HSTs, during overall progradational settings, where high-frequency collapse events are more likely to occur in composite HSTs vs. TSTs. The Lennard Shelf data set (after Playton and Kerans 2015b) suggests that highfrequency margin failure occurs at accommodation minima; thus, debris deposits have sequence stratigraphic significance and can be used to further delineate the internal architecture of composite HSTs. As the debris deposits are less prevalent in composite TSTs, internal high-frequency sequence architecture is likely obscured and more difficult to define.

Signals of Ecological Stress: In addition to accommodation controls, carbonate systems also strongly respond to changes in environmental conditions, resulting in perturbations in productivity and the active source factories that contribute to middle-slope deposits. The ability to examine sediment successions that pre- and postdate the F-F boundary allows for general facies trends and relationships to be developed. These are not stacking patterns per se; rather, they are signals or diagnostic features that may indicate temporal proximity to a major biotic crisis (Fig. 26). In the Lennard Shelf case, the pre-extinction lead- 
Middle Slope Stacking Patterns - ecological signals

A) pre-extinction biotic stress (idealized)

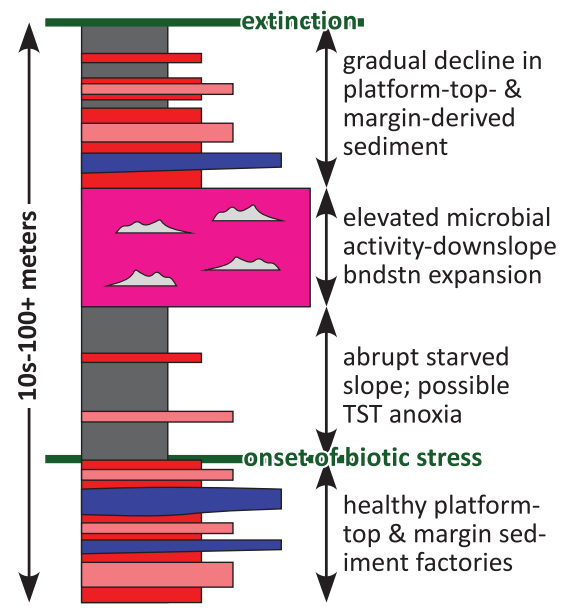

microbial boundstone

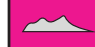

\section{B) post-extinction recovery, single rebounding factory}

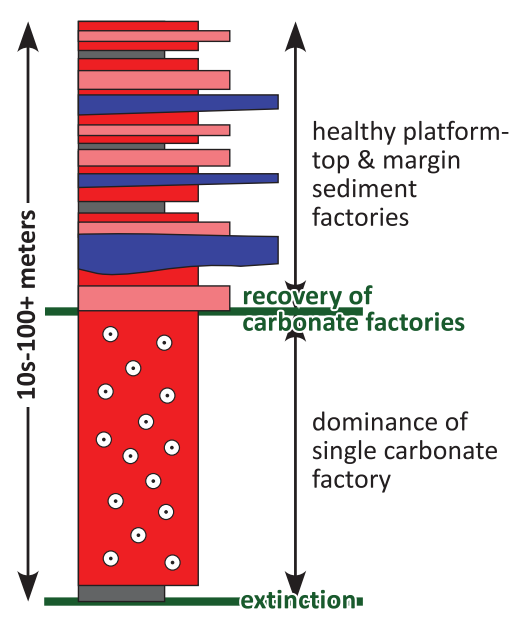

\section{C) post-extinction recovery, microbial bloom}

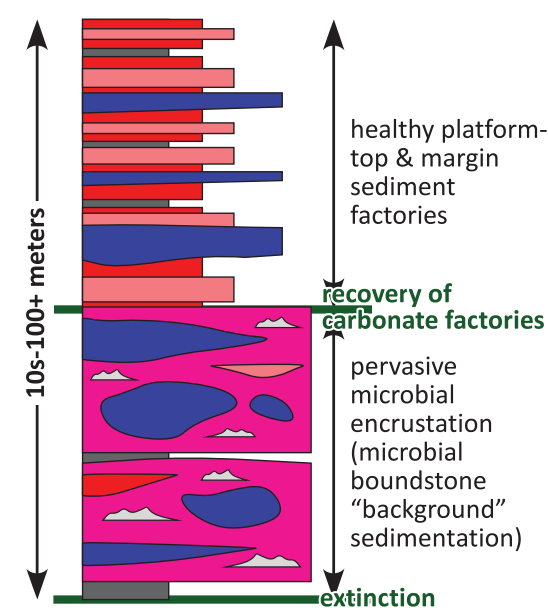

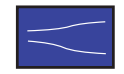

debris deposits

$\stackrel{\text { ooids }}{\odot}$ grain-dom'd deposits

mud-dom'd deposits

FIG. 26.-Idealized vertical facies successions in a middle-slope setting showing precursor and aftermath indications of an extinction interval. Successions are schematic to capture the breadth of observations; thus, exact vertical relationships and combinations can vary. dom'd $=$ dominated; bndstn = boundstone. A) Facies and relationships indicating the onset of biotic stress and lead-up period prior to an extinction boundary. B) Succession indicating the early rebound of a single carbonate factory subsequent to an extinction boundary, while other factories recover later. C) Succession indicating ubiquitous microbial encrustation subsequent to an extinction boundary, suggesting "continuous" microbial growth and episodic deposition of other sediment types.

up period entailed an increase in biotic stresses that were reflected in the slope through changes in sediment type (Fig. 26A). Fairly abrupt starved slope intervals, dominated by muddy background deposits with little margin or platform-top contribution, indicate a temporary pause in the previously flourishing factories that normally dominated slope deposition. These intervals may correspond to anoxic events that are manifested through transgressions and thus can have sequence stratigraphic significance (i.e., Frasnian Sequence 7 TST; Figs. 18, 19; also see Playton and Kerans 2015b). Increased occurrences of microbial boundstone, such as downslope expansion of the encrusted upper-slope environment, can represent elevated microbial activity related to the opportunistic response to other struggling biota. Immediately prior to the extinction boundary itself, successions showing an upward decrease in the proportions of margin- and platform-top-derived sediment can reflect the decline of species and productivity. The exact vertical ordering and combinations of these indicators of biotic stress are variable and will depend on the dynamics of each system, but still provide a set of criteria with which to predict the preceding response in carbonate slope deposits to an extinction boundary.

Following the F-F extinction boundary, we observed two styles of sedimentation in middle-slope settings before margin and platformtop factories recovered and slope deposits returned to the typical, expected successions (Fig. 26B, C). In one example, an anomalously thick stack of oolitic grain-dominated deposits overwhelmed the slope (Fig. 26B), reflecting the early rebound of the ooid shoal factory, while the remaining factories were not yet reestablished in the extinction aftermath. Other areas exhibited pervasive microbial encrustation of the middle slope, with debris- and grain-dominated deposits interspersed and suspended in a labyrinth of boundstone (Fig. 26C). The boundstone patterns suggest a near-continuous growth and accumulation, conceptually similar to "background sedimentation" and seemingly not partitioned in time and space, with episodic debris and grain shedding events. In general, these trends describe a period of postextinction recovery, during which the majority of the former carbonate factories require time to reequilibrate and reestablish, and open a window of opportunity for niche-filling microbial communities and/or more resilient factories to produce and deposit prolifically in light of the reduced competition. In our data set, this stage seems to be about the duration of a composite-scale systems tract and happens to coincide with the Famennian Sequence 1 TST, but the sequence stratigraphic significance and linkage is not well understood.

Caution With Middle-Slope Stacking Patterns: Caution should be taken when applying or interpreting the aforementioned criteria for slope sequence stratigraphy. The nature of carbonate slopes associated with steep, reefal margins is inherently highly heterogeneous laterally and vertically, and since debris deposits are a key indicator facies, their presence is not always sufficient for optimal sequence interpretation. Strike variability needs to be appreciated, and supporting data, such as carbon isotope profiles, can significantly aid and corroborate systems tract definition (see Hillbun et al. 2016). This assumes that debris deposits are generated via intrinsic collapse processes related to margin trajectory. However, extrinsic triggering 
mechanisms (e.g., seismicity and tsunamis) are well documented and need to be considered to avoid erroneous interpretations. Furthermore, the Lennard Shelf system is one that constructed great relief over a long period of geologic time, developed near-vertical escarpments, and contained a substantial microbial component concentrated in the margins for most of its evolution; other carbonate systems will undoubtedly have their own particularities that may or may not correspond directly to the patterns discussed here.

\section{CONCLUSIONS}

Carbonate slopes are exceptional repositories of sediment and recorders of carbonate system evolution. The CBCP generated a high-resolution, shelf-to-basin sequence stratigraphic framework across the Lennard Shelf that allows for unique examination of carbonate margin and slope development within highly constrained accommodation and ecological contexts. We achieved this through integration of multiple independent data sets extracted from the rock record to generate a high-confidence suite of constraints for sequence stratigraphic interpretation in variable settings. We here propose carbonate margin-to-basin sequence stratigraphic conceptual models and facies successions for composite-scale sequences throughout supersequence TST, MFS, and HST evolution and across a global biotic crisis. We find that deposit proportions, facies associations, vertical stratigraphic patterns, margin architecture, and shelf-to-basin geometry vary with respect to position within the supersequence and in terms of lead-up or recovery periods around an extinction interval. The concepts herein provide relationships to link seismic-scale architecture with fine-scale heterogeneity and predictive tools to better characterize these highly complex systems. These findings are useful for subsurface industry applications and also lay a foundation for further academic research.

\section{ACKNOWLEDGMENTS}

We especially thank the Aboriginal tribes of the Bunaba and Gooniyandi (Kuniandi) people, who allowed us to conduct this research on their sacred lands. Thanks to Paul Montgomery and Peter Cawood for the integrated chronostratigraphic vision and to Phil Playford for introduction to the outcrop belt. Special thanks to reviewers John Weissenberger, Ken Potma, William Morgan, Brian Pratt, and Charles Kerans for feedback and guidance that greatly improved the quality of the manuscript. Funding was supplied by the Australian Research Council Linkage Program (grant LP0883812), ARC-QEII Grant Program, ARC-DORA-3 Grant Program, MERIWA, WAERA, CSIRO, Buru, Chevron Australian Business Unit, Chevron Energy Technology Company, the University of Greenwich, and Chemostrat, Ltd. Field support and safety assistance were provided by Wundargoodie Aboriginal Safaris (Colin and Maria Morgan and family and crew), the Geological Survey of Western Australia, Chevron Australian Business Unit, and Steve Meyer, Sean O'Connell, and Bill Robinson of Chevron. Thanks to Windjana Gorge National Park, Napier Downs, the Mimbi Community, Mount Pierre Station, Fossil Downs Station, Brooking Downs Station, the Pillara Mine, and the Cadjebut Mine for field area access and resources. Thanks to R. Addenbrooke, H. Allen, A. Duffy, G Beacher, M. Diamond, T. Holland, J. Hsieh, L. Lanci, K. Liebe, E. Maslen, L. McEvoy, S. Shoepfer, U. Singh, M. Thorp, T. Tobin, A. Vonk, F. Wellmann, and K. Williford for field assistance. Thanks to E. Davies, M. Ducea, J. Klemm, F. Pardini, T. Raub, G. Rotberg, J. Sano, S. Slotznick, P. Ward, and M. Wright for logistical and/or analytical contributions. R.M. Hocking and P.W. Haines publish with the permission of the Executive Director of the Geological Survey of Western Australia.

\section{REFERENCES}

Becker RT, House MR. 1997. Sea level changes in the Upper Devonian of the Canning Basin, Western Australia. Courier Forschungsinstitut Senckenberg 199:129-146.

Becker RT, House MR, Kirchgasser WT. 1993. Devonian goniatite biostratigraphy and timing of facies movements in the Frasnian of the Canning Basin, Western Australia. In Hailwood EA, Kidd RB (Editors). High Resolution Stratigraphy, Special Publication 70: Geological Society, London. p. 293-321.

Begg J. 1987. Structuring and controls on Devonian reef development on the northwest Barbwire and adjacent terraces, Canning Basin. Australian Petroleum Exploration Association Journal 27:137-151.

Bellian JA, Playton TE, Kenter JAM, Harris PM, Kerans C. 2012. The reciprocal nature of carbonate and siliciclastic-dominated slope channel deposits (Abstract): American Association of Petroleum Geologists Annual Convention and Exhibition, April 22-25, 2012; Long Beach, California.

Bing X, Zhaoyan G, Qiang L, Chengyuan W, Zhenliang L. 2003. Carbon isotopic record from Upper Devonian carbonates at Dongcun in Guilin, southern China, supporting the world-wide pattern of carbon isotope excursions during Frasnian-Famennian transition. Chinese Science Bulletin 48:1259-1264.

Brown AA, Loucks RG. 1993. Influence of sediment type and depositional processes on stratal patterns in the Permian Basin-margin Lamar Limestone, McKittrick Canyon, Texas. In Loucks RG, Sarg JF (Editors). Carbonate Sequence Stratigraphy, Memoir 57: American Association of Petroleum Geologists, Tulsa, Oklahoma. p. 133-156.

Buggisch W, Joachimski MM. 2006. Carbon isotope stratigraphy of the Devonian of Central and Southern Europe. Palaeogeography, Palaeoclimatology, and Palaeoecology 240:68-88.

Clayton JL, Kerans C. 2013. Reservoir compartmentalization of a deep-water ooid fan, Happy Field, Permian Basin. In Verwer K, Playton TE, Harris PM (Editors). Deposits, Architecture, and Controls of Carbonate Margin, Slope, and Basinal Settings, Special Publication 105: SEPM (Society for Sedimentary Geology), Tulsa, Oklahoma. p. 359-383.

Collins JF, Kenter JAM, Harris PM, Kuanysheva G, Fischer DJ, Steffen KL. 2006. Facies and reservoir quality variations in the Late Visean to Bashkirian outer platform, rim, and flank of the Tengiz Buildup, Pricaspian Basin, Kazakhstan. In Harris PM, Weber LJ (Editors). Giant Hydrocarbon Reservoirs of the World: From Rocks to Reservoir Characterization and Modeling, Memoir 88: American Association of Petroleum Geologists, Tulsa, Oklahoma. p. 55-95.

Collins JF, Narr W, Harris PM, Playton TE, Jenkins S, Tankersley T, Kenter JAM. 2013. Lithofacies, depositional environments, burial diagenesis, and dynamic field behavior in a Carboniferous slope reservoir, Tengiz Field (Republic of Kazakhstan), and comparison with outcrop analogs. In Verwer K, Playton TE, Harris PM (Editors). Deposits, Architecture, and Controls of Carbonate Margin, Slope, and Basinal Settings, Special Publication 105: SEPM (Society for Sedimentary Geology), Tulsa, Oklahoma. p. 50-83.

Cook HE, McDaniel PN, Mountjoy EW, Pray LC. 1972. Allochthonous carbonate debris flows at Devonian bank ('reef') margins, Alberta, Canada. Bulletin of Canadian Petroleum Geology 20(3):439-497.

Cook HE, Mullins HT. 1983. Basin margin environment. In Scholle PA, Bebout DG, Moore CH (Editors). Carbonate Depositional Environments, Memoir 33: American Association of Petroleum Geologists, Tulsa, Oklahoma. p. 539-618.

Copp IA. 2000. Subsurface facies analysis of Devonian reef complexes, Lennard Shelf, Canning Basin, Western Australia: Geological Survey of Western Australia Report 58, $127 \mathrm{p}$

Davies EJ, Ratcliffe KT, Montgomery P, Pomar L, Ellwood BB, Wray DS 2013. Magnetic susceptibility $(\chi)$ stratigraphy and chemostratigraphy applied to an isolated carbonate platform reef complex; Llucmajor Platform, Mallorca. In Verwer K, Playton TE, Harris PM (Editors). Deposits, Architecture, and Controls of Carbonate Margin. Slope, and Basinal Settings, Special Publication 105: SEPM (Society for Sedimentary Geology), Tulsa, Oklahoma. p. 142-156.

Droxler AW, Schlager W. 1985. Glacial versus interglacial sedimentation rates and turbidite frequency in the Bahamas. Geology 13:799-802. 
Drummond BJ, Sexton MJ, Barton TJ, Shaw RD. 1991. The nature of faulting along the margins of the Fitzroy Trough, Canning Basin, and implications for the tectonic development of the trough. Exploration Geophysics 22:111115 .

Eberli GP, Bernoulli D, Sanders D, Vecsei A. 1993. From aggradation to progradation; The Maiella Platform, Abruzzi, Italy. In Simo JAT, Scott RW, Masse JP (Editors). Cretaceous Carbonate Platforms, Memoir 56: American Association of Petroleum Geologists, Tulsa, Oklahoma. p. 213-232.

Fitchen WM, Starcher MA, Buffler RT, Wilde GL. 1995. Sequence stratigraphic framework and facies models of early Permian carbonate platform margins, Sierra Diablo, West Texas. In Garber RA, Lindsay RF (Editors). Wolfcampian-Leonardian Shelf Margin Facies of the Sierra Diablo-Seismic Scale Models for Subsurface Exploration, Field Trip Guidebook 95-97: West Texas Geological Society, Midland, Texas. p. 23-66.

Frost EL III. 2007. Facies heterogeneity, platform architecture and fracture patterns of the Devonian reef complexes, Canning Basin, Western Australia [unpublished $\mathrm{PhD}$ dissertation]: University of Texas at Austin, $156 \mathrm{p}$.

Frost EL III, Kerans C. 2010. Controls on syndepositional fracture patterns, Devonian reef complexes, Canning Basin, Western Australia. Journal of Structural Geology 32:1231-1249.

George AD, Chow N. 2002. The depositional record of the Frasnian/Famennian boundary interval in a forereef succession, Canning Basin, Western Australia. In Racki G, House MR (Editors). Late Devonian biotic crisis; Ecological, depositional, and geochemical records. Palaeogeography, Palaeoclimatology, Palaeoecology 181:347-374.

George AD, Playford PE, Powell CMcA, Tornatora PM. 1997. Lithofacies and sequence development on an Upper Devonian mixed carbonate-siliciclastic fore-reef slope, Canning Basin, Western Australia. Sedimentology 44:843867.

George AD, Trinajstic KM, Chow N. 2009. Frasnian reef evolution and palaeogeography, SE Lennard Shelf, Canning Basin, Australia. In Konigshof P (Editor). Devonian Change: Case Studies in Palaeogeography and Palaeoecology, Special Publication 314: Geological Society, London. p. 73-107.

Girard C, Klapper G, Feist R. 2005. Subdivision of the Terminal Frasnian Linguiformis Conodont Zone, revision of the correlative interval of Montagne Noire Zone 13, and discussion of stratigraphically significant associated Trilobites. In Over JD, Morrow JR, Wignall PB (Editors). Understanding Late Devonian and Permian-Triassic Biotic and Climatic Events: Towards an Integrated Approach, Developments in Paleontology and Stratigraphy 20: Elsevier, Amsterdam. p. 181-198.

Goldhammer RK, Dunn PA, Hardie LA. 1990. Depositional cycles, composite sea level changes, cycle stacking patterns, and the hierarchy of stratigraphic forcing: Examples from platform carbonates of the Alpine Triassic. Geological Society of America Bulletin 102:535-562.

Goldhammer RK, Lehmann PJ, Dunn PA. 1993. The origin of high-frequency platform carbonate cycles and third-order sequences (Lower Ordovician El Paso Group, west Texas): Constraints from outcrop data and stratigraphic modeling. Journal of Sedimentary Petrology 63:318-359.

Goldhammer RK, Oswald EJ, Dunn PA. 1991. The hierarchy of stratigraphic forcing: An example from middle Pennsylvanian shelf carbonates of the Paradox Basin. In Franseen E, Watney L (Editors). Sedimentary Modeling. Computer Simulation of Depositional Sequences, Bulletin 233: Kansas Geological Survey, Lawrence. p. 361-413.

Gradstein FM, Ogg J, Schmitz M, Ogg G (Editors). 2012. The Geologic Time Scale 2012: Elsevier, Oxford, UK. 1176 p.

Grammer GM, Ginsburg RN. 1992. Highstand versus lowstand deposition on carbonate platform margins: Insight from Quaternary foreslopes in the Bahamas. Marine Geology 103:125-136.

Hansma J, Tohver E, Yan M, Trinajstic K, Roelofs B, Peek S, Slotznick SP, Kirschvink J, Playton TE, Haines PW, Hocking RM. 2015. Late Devonian carbonate magnetostratigraphy from the Oscar and Horse Spring Ranges, Lennard Shelf, Canning Basin, Western Australia. Earth and Planetary Science Letters 409:232-242.

Hillbun K. 2015. Re-evaluating the Late Devonian mass extinction: A new perspective from the Canning Basin, Western Australia [unpublished $\mathrm{PhD}$ dissertation]: University of Washington, Seattle, 278 p.
Hillbun K, Playton TE, Katz DA, Tohver E, Trinajstic K, Haines PW, Hocking RM, Roelofs B, Montgomery P. 2016. Correlation and sequence stratigraphic interpretation of Upper Devonian carbonate slope facies using carbon isotope chemostratigraphy, Lennard Shelf, Canning Basin, Western Australia. In Playton TE, Kerans C, Weissenberger J (Editors). New Advances in Devonian Carbonates: Outcrop Analogs, Reservoirs, and Chronostratigraphy, Special Publication 107: SEPM (Society for Sedimentary Geology), Tulsa, Oklahoma.

Hillbun K, Playton TE, Tohver E, Ratcliffe K, Trinajstic K, Roelofs B, Caulfield-Kerney S, Wray D, Haines PW, Hocking RM, Katz DA, Montgomery P, Ward P. 2015. Upper Kellwasser carbon isotope excursion pre-dates the F-F boundary in the Upper Devonian Lennard Shelf carbonate system, Canning Basin, Western Australia. Palaeogeography, Palaeoclimatology, and Palaeoecology 438:180-190.

Janson X, Kerans C, Bellian JA, Fitchen W. 2007. Three-dimensional geological and synthetic seismic model of Early Permian redeposited basinal carbonate deposits, Victorio Canyon, west Texas. American Association of Petroleum Geologists Bulletin 91:1405-1436.

Janson X, Kerans C, Loucks R, Marhx MA, Reyes C, Murguia F. 2011. Seismic architecture of a Lower Cretaceous platform-to-slope system, Santa Agueda and Poza Rica Fields, Mexico. American Association of Petroleum Geologists Bulletin 95(1):105-146.

Joachimski MM, Pancost RD, Freeman KH, Ostertag-Henning C, Buggisch W. 2002. Carbon isotope geochemistry of the Frasnian-Famennian transition. Palaeogeography, Palaeoclimatology, Palaeoecology 181:91-109.

Katz D, Buoniconti M, Montañez I, Swart P, Eberli G, Smith L. 2007. Timing and local perturbations to the carbon pool in the Lower Mississippian Madison Limestone, Montana and Wyoming. Palaeogeography, Palaeoclimatology, Palaeoecology 256:231-253.

Katz DA, Playton TE, Bellian JA, Harris PM, Harrison C, Maharaja A. 2010. Slope heterogeneity and production results in a steep-sided Upper Paleozoic isolated carbonate platform reservoir, Karachaganak Field, Kazakhstan: Society of Petroleum Engineers Caspian Carbonates Technology Conference Paper 139960, Atyrau, Kazakhstan. p. 1-7.

Kaufmann B. 2006. Calibrating the Devonian Time Scale: A synthesis of U-Pb ID-TIMS ages and conodont stratigraphy. Earth Science Reviews 76:175190

Kerans C. 1985. Petrology of Devonian and Carboniferous carbonates of the Canning and Bonaparte Basins: Western Australian Mining and Petroleum Research Institute Report 12. 203 p.

Kerans C. 1995. Use of one- and two-dimensional cycle analysis in establishing high frequency sequence frameworks. In Read JF, Kerans C, Weber LJ (Editors). Milankovitch Sea Level Changes, Cycles and Reservoirs on Carbonate Platforms in Greenhouse and Ice-House Worlds, Short Course Notes 35: SEPM (Society for Sedimentary Geology), Tulsa, Oklahoma. p. 103-123.

Kerans C. 2002. Styles of rudist buildup development along the northern margin of the Maverick Basin, Pecos River Canyon, southwest Texas. Transactions Gulf Coast Association of Geological Societies 52:501-516.

Kerans C, Fitchen WM. 1995. Sequence hierarchy and facies architecture of a carbonate-ramp system: San Andres Formation of Algerita Escarpment and western Guadalupe Mountains, West Texas and New Mexico, Report of Investigations 235: Bureau of Economic Geology, Austin, Texas. 86 p.

Kerans C, Kempter K. 2002. Hierarchical stratigraphic analysis of a carbonate platform, Permian of the Guadalupe Mountains, Datapages Discovery Series 5: American Association of Petroleum Geologists, Tulsa, Oklahoma. CDROM.

Kerans C, Nance HS. 1991. High frequency cyclicity and regional depositional patterns of the Grayburg Formation, Guadalupe Mountains, New Mexico, Publication 91-32: Society of Sedimentary Geology Permian Basin Section, Midland, Texas. p. 53-69.

Kerans C, Tinker SW. 1997. Sequence Stratigraphy and Characterization of Carbonate Reservoirs, Short Course Notes 40: SEPM (Society for Sedimentary Geology), Tulsa, Oklahoma. 140 p.

Klapper G. 1989. The Montagne Noire Frasnian (Upper Devonian) Conodont Succession. In McMillan NJ, Embry AF, Glass DJ (Editors). Devonian of the World, Memoir 14: Canadian Society of Petroleum Geologists, Calgary, Alberta. p. 449-468. 
Klapper G. 1997. Graphic correlation of Frasnian (Upper Devonian) sequences in Montagne Noire, France, and western Canada. In Klapper G, Murphy MA, Talent JA (Editors). Paleozoic Sequence Stratigraphy, Biostratigraphy, and Biogeography: Studies in Honor of J. Granville ("Jess") Johnson, Special Paper 321: Geological Society of America, Boulder, Colorado. p. 113-129.

Klapper G. 2007. Frasnian (Upper Devonian) conodont succession at Horse Spring and correlative sections, Canning Basin, Western Australia. Journal of Paleontology 81:513-537.

Lehrmann DJ, Goldhammer RK. 1999. Secular variation in parasequence and facies stacking patterns of platform carbonates: A guide to application of stacking-pattern analysis in strata of diverse ages and settings. In Harris PM, Saller AH, Simo JA (Editors). Advances in Carbonate Sequence Stratigraphy: Application to Reservoirs, Outcrops, and Models, Special Publication 63: SEPM (Society for Sedimentary Geology), Tulsa, Oklahoma. p. 187-226.

Montgomery P, Ratcliffe KT, Wray D. 2011. Application of whole rock inorganic geochemistry to stratigraphic understanding of mixed carbonate evaporite reservoirs, an example from the First Eocene of the Wafra Field, PZ (Abstract): American Association of Petroleum Geologists Annual Convention and Exhibition; April 10-13, 2011; Houston, Texas.

Montgomery SL. 1996. Permian 'Wolfcamp' limestone reservoirs, Powell Ranch Field, eastern Midland Basin. American Association of Petroleum Geologists Bulletin 80:1349-1365.

Osleger DA, Tinker SW. 1999. Three-dimensional architecture of Upper Permian high-frequency sequences, Yates-Capitan shelf margin, Permian Basin, USA. In Harris PM, Saller AH, Simo JA (Editors). Advances in Carbonate Sequence Stratigraphy: Application to Reservoirs, Outcrops, and Models, Special Publication 63: SEPM (Society for Sedimentary Geology), Tulsa, Oklahoma. p. 169-185.

Playford PE. 1980. Devonian 'great barrier reef' of the Canning Basin, Western Australia: American Association of Petroleum Geologists Bulletin 64:814-840.

Playford PE. 1984. Platform-margin and marginal-slope relationships in Devonian reef complexes of the Canning Basin. In Purcell PG (Editor). The Canning Basin, Western Australia: Geological Society of Australia and Petroleum Exploration Society of Australia, Canning Basin Symposium, Perth, p. 189-234.

Playford PE, Hocking RM, Cockbain AE. 2009. Devonian Reef Complexes of the Canning Basin, Western Australia, Bulletin 145: Geological Survey of Western Australia, Perth. $444 \mathrm{p}$.

Playford PE, Hocking RM, Cockbain AE. 2016. Devonian reef complexes of the Canning Basin, Western Australia: A historical review. In Playton TE, Kerans C, Weissenberger J (Editors). New Advances in Devonian Carbonates: Outcrop Analogs, Reservoirs, and Chronostratigraphy, Special Publication 107: SEPM (Society for Sedimentary Geology), Tulsa, Oklahoma.

Playton TE. 2008. Characterization, variations, and controls of reef-rimmed carbonate foreslopes [unpublished $\mathrm{PhD}$ dissertation]: The University of Texas at Austin, $283 \mathrm{p}$.

Playton TE, Hocking RM, Montgomery P, Tohver E, Hillbun K, Katz DA, Haines PW, Trinajstic K, Yan M, Hansma J, Pisarevsky S, Kirschvink J, Cawood P, Grice K, Tulipani S, Ratcliffe K, Wray D, Caulfield-Kerney S, Ward P, Playford PE. 2013. Development of a regional stratigraphic framework for Upper Devonian reef complexes using integrated chronostratigraphy: Lennard Shelf, Canning Basin, Western Australia. In Keep M, Moss SJ (Editors). Sedimentary Basins of Western Australia IV: Proceedings of the Petroleum Exploration Society of Australia Symposium; August 18 21, 2013; Perth, Western Australia, 14 p.

Playton TE, Janson X, Kerans C. 2010. Carbonate slopes. In James NP, Dalrymple RW (Editors). Facies Models 4, GEOtext 6: Geological Association of Canada, St. Johns, NL. p. 449-476.

Playton TE, Kerans C. 2015a. Late Devonian carbonate margins and foreslopes of the Lennard Shelf, Canning Basin, Western Australia, Part A Development during backstepping and the aggradation-to-progradation transition. Journal of Sedimentary Research 85:1334-1361.

Playton TE, Kerans C. 2015b. Late Devonian carbonate margins and foreslopes of the Lennard Shelf, Canning Basin, Western Australia, Part B Development during progradation and across the Frasnian-Famennian biotic crisis. Journal of Sedimentary Research 85:1362-1392.
Raup DM, Sepkoski JJ. 1982. Mass extinctions in the marine fossil record. Science 215:1501-1503.

Read JF. 1995. Overview of carbonate platform sequences, cycle stratigraphy and reservoirs in greenhouse and icehouse worlds. In Read JF, Kerans C, Weber LJ (Editors). Milankovitch Sea Level Changes, Cycles and Reservoirs on Carbonate Platforms in Greenhouse and Ice-House Worlds, Short Course Notes 35: SEPM (Society for Sedimentary Geology), Tulsa, Oklahoma. p. 1106.

Roelofs B, Playton TE, Barham M, Trinajstic K. 2015. Upper Devonian microvertebrates from the Canning Basin, Western Australia. Acta Geologica Polonica 65:69-101.

Sarg JF, Markello JR, Weber LJ. 1999. The second-order cycle, carbonateplatform growth, and reservoir, source, and trap prediction. In Harris PM, Saller AH, Simo JA (Editors). Advances in Carbonate Sequence Stratigraphy: Application to Reservoirs, Outcrops, and Models, Special Publication 63: SEPM (Society for Sedimentary Geology), Tulsa, Oklahoma. p. 11-34.

Stephens NP, Sumner DY. 2003. Late Devonian carbon isotope stratigraphy and sea level fluctuations, Canning Basin, Western Australia. Palaeogeography, Palaeoclimatology, Palaeoecology 191:203-219.

Tinker SW. 1998. Shelf-to-basin facies distribution and sequence stratigraphy of a steep-rimmed carbonate margin: Capitan depositional system, McKittrick Canyon, New Mexico and Texas. Journal of Sedimentary Research 68:1146-1174.

Trinajstic K, George AD. 2009. Microvertebrate biostratigraphy of Upper Devonian (Frasnian) carbonate rocks in the Canning and Carnarvon Basins of Western Australia. Palaeontology 52:641-659.

Tulipani S, Grice K, Greenwood PF, Haines PW, Sauer PE, Schimmelmann A, Summons RE, Foster CB, Bottcher ME, Playton TE, Schwark L. 2014 Changes of palaeoenvironmental conditions recorded in Late Devonian reef systems from the Canning Basin, Western Australia: A biomarker and stable isotope approach. Gondwana Research 28:1500-1515.

Tulipani S, Grice K, Greenwood PF, Schwark L, Bottcher ME, Summons RE, Foster CB. 2015. Molecular proxies as indicators of freshwater incursiondriven salinity stratification. Chemical Geology 409:61-68.

Ward WB. 1999. Tectonic control on backstepping sequences revealed by mapping of Frasnian backstepped platforms, Devonian reef complexes, Napier Range, Canning Basin, Western Australia. In Harris PM, Saller AH, Simo JA (Editors). Advances in Carbonate Sequence Stratigraphy: Application to Reservoirs, Outcrops, and Models, Special Publication 63: SEPM (Society for Sedimentary Geology), Tulsa, Oklahoma. p. 47-74.

Whalen MT, Eberli GP, van Buchem FSP, Mountjoy EW. 2000. Facies architecture of Upper Devonian carbonate platforms, Rocky Mountains, Canada. In Homewood PW, Eberli GP (Editors). Genetic Stratigraphy on the Exploration and Production Scales-Case Studies from the Pennsylvanian of the Paradox Basin and the Upper Devonian of Alberta, Mémoire 24: Bulletin des Centre Recherche Elf Exploration-Production, Pau, France. p. $139-178$.

Workum RH, Hedinger AS. 1989. Burnt Timber and Scalp Creek margins, Frasnian Fairholme reef complex, Alberta. In Geldsetzer HHJ, James NP, Tebbutt GE (Editors). Reefs, Canada and Adjacent Areas, Memoir 13: Canadian Society of Petroleum Geologists, Calgary, Alberta. p. 552-556.

Ziegler W, Sandberg CA. 1990. The Late Devonian Standard Conodont Zonation. Courier Forschungsinstitut Senckenberg 121:1-115. 


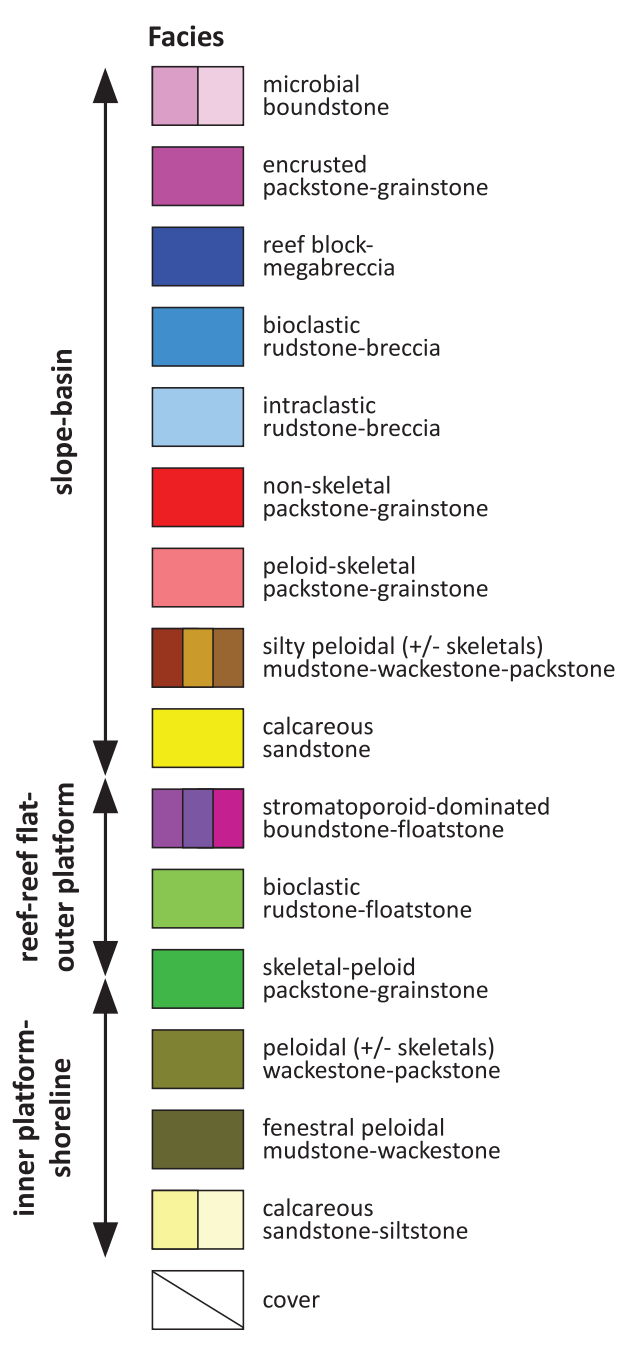

Conodont Samples/Picks

Famennian Upper marginifera $\longrightarrow$ Famennian Upper crepida-marginifera $\longrightarrow$ Famennian triangularis-crepida $\longrightarrow$ Frasnian Zone $13 \longrightarrow$

Frasnian Zones 5-12 $\longrightarrow$

Frasnian Zones 1-4 $\longrightarrow$

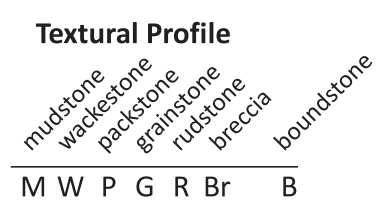

Paleomagnetic Polarity

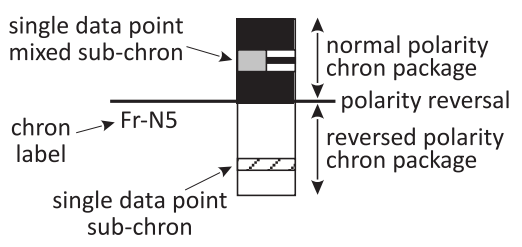

\section{Stable Carbon Isotopes}

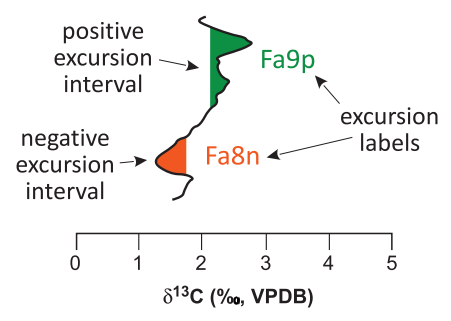

\section{Surfaces}

- outcrop walk-out

-F-F Frasnian-Famennian boundary

- G-F Givetian-Frasnian boundary

FVS falsiovalis global excursion

LKW Lower Kellwasser global excursion

UKW Upper Kellwasser global excursion

ENK Enkeberg global excursion

\section{Sequence Stratigraphy}

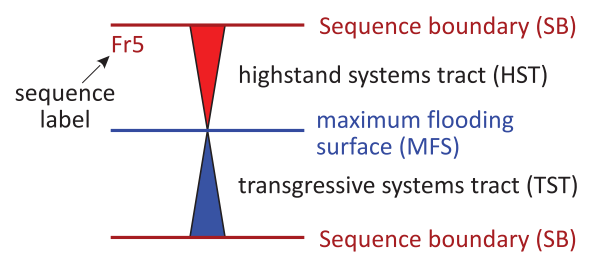

ApPendix 1.-Legend for measured sections, core descriptions, and correlations, including schemes for CBCP universal facies, conodont picks, description textural profiles, paleomagnetic polarity reversals, stable carbon isotopes, surfaces markers, and sequence stratigraphy. 
Appendix 2.-Windjana North A (WNA) measured section with correlation constraints. See Appendix 1 for legend and Figure 1 for location along the Lennard Shelf. WNA is located in the Napier Ranges just northwest of Windjana Gorge (17 $23^{\prime} 35.49^{\prime \prime} \mathrm{S}, 124^{\circ} 57^{\prime} 14.43^{\prime \prime} \mathrm{E}$ to $\left.17^{\circ} 23^{\prime} 50.92^{\prime \prime S}, 124^{\circ} 56^{\prime} 58.08^{\prime \prime E}\right)$. Paleogeographically, the Windjana Gorge area reflects a very narrow point along the Lennard Shelf (less than 5-km shelf width in places) that is rich in siliciclastics and part of a linear margin tens of kilometers long, but with complex, finer-scale (kilometer or less) reentrant-promontory configurations superimposed along strike. WNA is Middle-Upper Frasnian in age, based on physical walk-outs to key control outcrops (i.e., the Classic Face in Windjana Gorge; Playford et al. 2009, Playton and Kerans 2015a). WNA facies consist of (1) cyclic skeletal-peloid grainstones-packstones, bioclastic rudstones-floatstones, peloidal packstoneswackestones-mudstones, and siliciclastics, representing inner platform-top settings; and (2) cyclic skeletal-peloid grainstones-packstones, bioclastic rudstones-floatstones, and in situ, bedded stromatoporoid framestones, indicative of outer platform-top to reef-flat settings. WNA facies transition upward from inner platform-top assemblages to outer platform-top to reef-flat assemblages. Inner platform-top carbonates are commonly dolomitic, whereas outer platform to reefflat carbonates are dominantly limestone, with variable degrees of intermixed siliciclastics in both. Physical walk-outs between WNA, WNB, and WS measured sections were achieved.

\section{Windjana North A (WNA) Section}

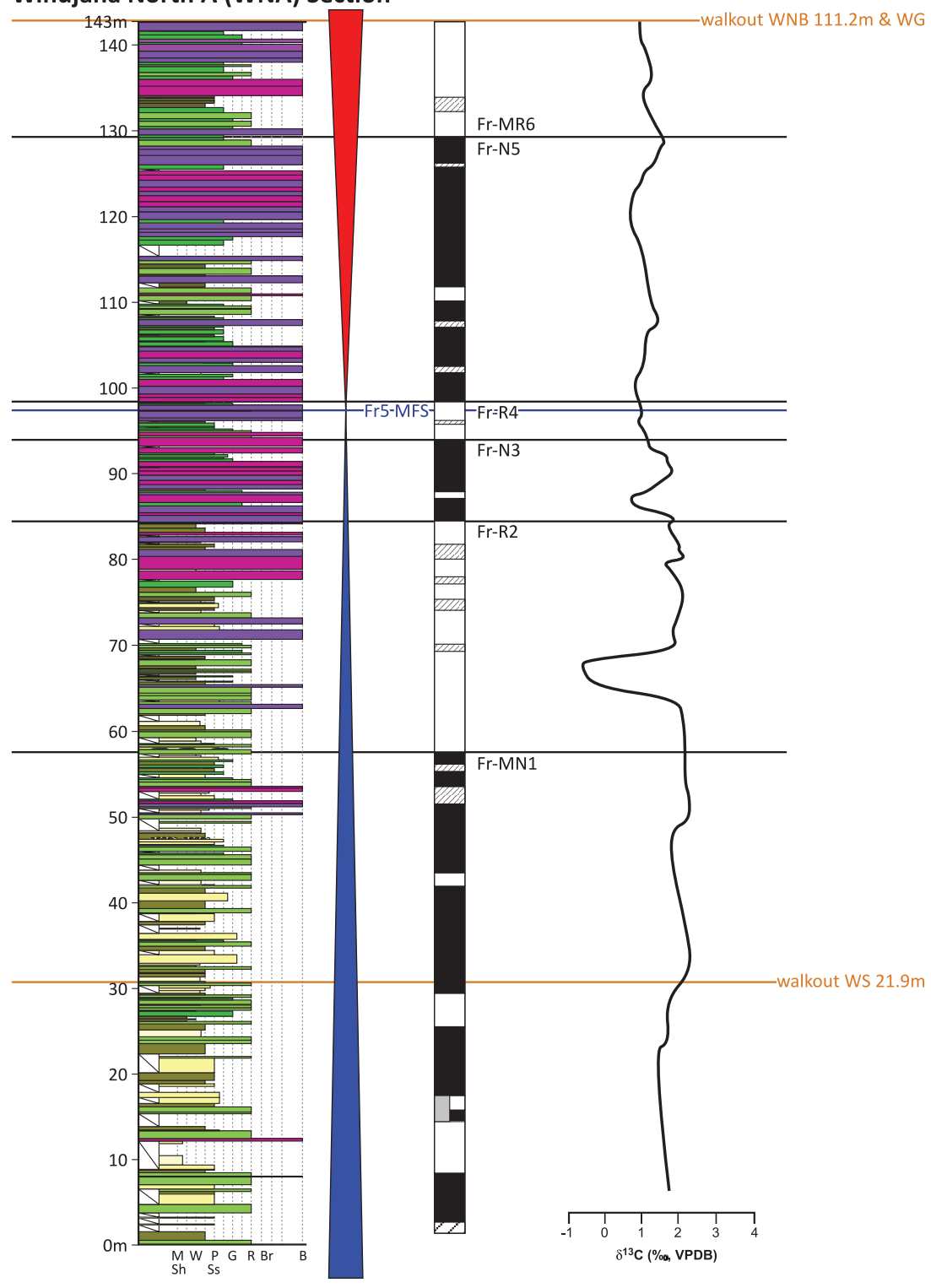




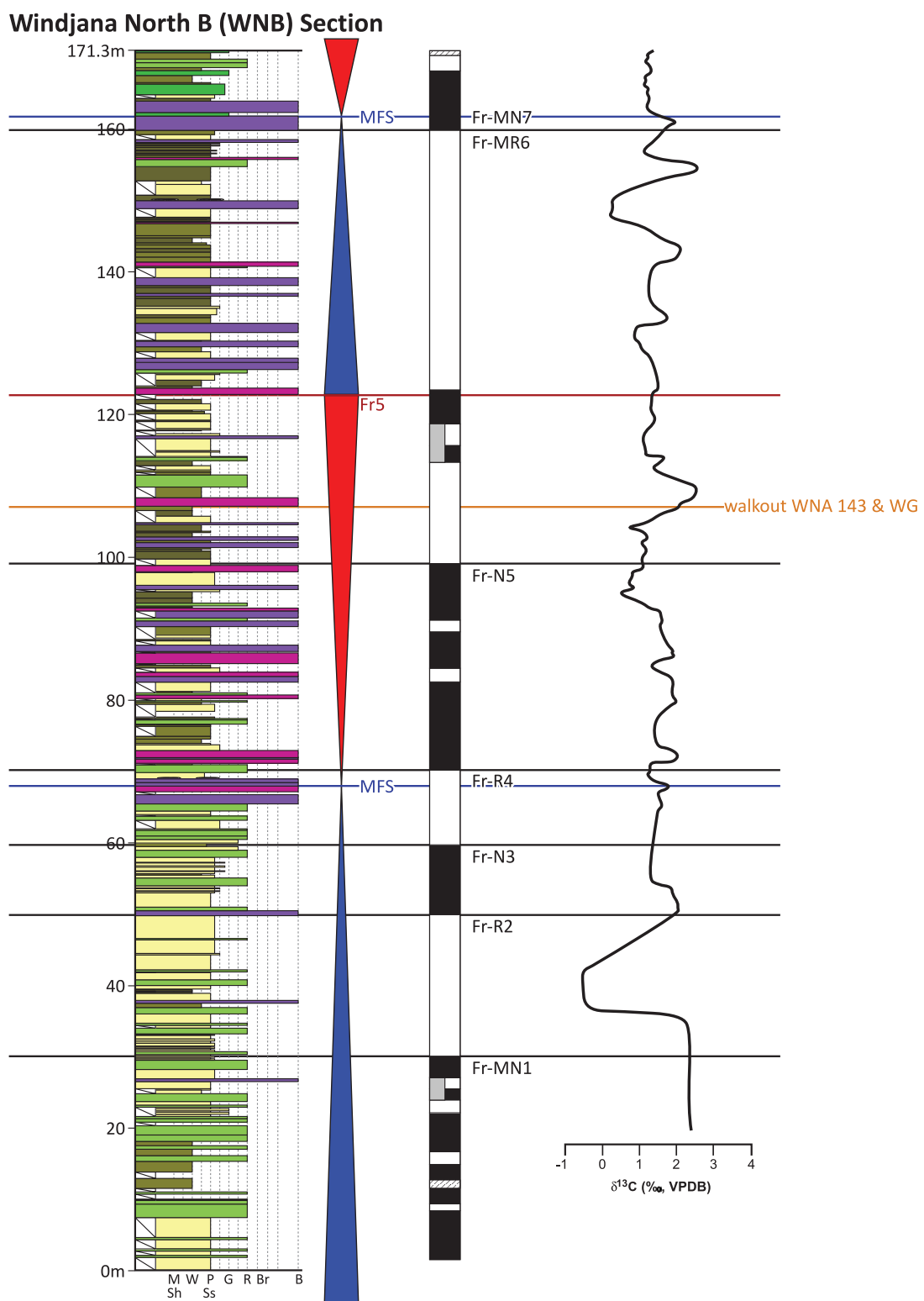

Appendix 3.-Windjana North B (WNB) measured section with correlation constraints. See Appendix 1 for legend and Figure 1 for location along the Lennard Shelf. WNB is located about $900 \mathrm{~m}$ alongstrike of WNA $\left(17^{\circ} 23^{\prime} 54.31\right.$ "S, $124^{\circ} 57^{\prime} 22.90^{\prime \prime} \mathrm{E}$ to $17^{\circ} 24^{\prime} 16.81^{\prime \prime S}$, $\left.124^{\circ} 57^{\prime} 11.05^{\prime \prime} \mathrm{E}\right)$, with a similar paleogeographic setting, age, and age control. Facies exposed at WNB consist of (1) cycles of skeletal-peloid grainstonespackstones, bioclastic rudstones-floatstones, peloidal packstones-wackestones-mudstones, and siliciclastics, representing inner platform-top settings; and (2) fingers of skeletal-peloid grainstones-packstones, bioclastic rudstonesfloatstones, and in situ, bedded stromatoporoid framestones, indicative of the transition into outer platform-top and reef-flat settings. Stratigraphically upward, WNB facies remain dominantly inner platform-top assemblages, with intervals of increased proportions of outer platform-top to reef-flat assemblages. Inner platform-top facies are commonly dolomitic, and outer platform to reef-flat intercalations are generally mixed limestone-dolomite, with variable degrees of intermixed siliciclastics in both. A physical walk-out between WNA and WNB measured sections was achieved, as well as a walk-out from WNB into Windjana Gorge. 
ApPendix 4.-Windjana Slope (WS) measured section with correlation constraints. See Appendix 1 for legend and Figure 1 for location along the Lennard Shelf. WS is located in the Napier Ranges just northwest of Windjana Gorge $\left(17^{\circ} 23^{\prime} 15.14^{\prime \prime} \mathrm{S}, 124^{\circ} 57^{\prime} 3.00^{\prime \prime} \mathrm{E}\right.$ to $\left.17^{\circ} 23^{\prime} 37.47^{\prime \prime} \mathrm{S}, 124^{\circ} 56^{\prime} 45.88^{\prime \prime} \mathrm{E}\right)$ and is paleogeographically similar to WNA in terms of the broader margin setting. WS is Middle to Upper Frasnian in age, based on physical walk-outs to key control outcrops (i.e., the Classic Face in Windjana Gorge), some recoverable biostratigraphic control, and correlations to key control sections. Facies exposed at WS consist of (1) intervals of stromatoporoid framestones with intercalations of skeletal-peloid grainstones-packstones and bioclastic rudstones-floatstones, representing reef core to reef-flat settings; (2) intervals of margin-derived brecciablocks, platform-derived grainstonepackstone of variable composition, graded siliciclastics, and tongues of in situ microbial boundstone, indicative of middle-slope settings and the middle-upperslope transition; and (3) intervals of bedded microbial boundstone representing upper-slope environments. Depositional dips in slope strata, corroborated by geopetals, range from 20 to $30^{\circ}$ after tilt correction. Stratigraphically upward, WS facies abruptly shift from in situ reefal margin settings to allochthonous middleslope settings across an irregular truncation surface, interpreted as a margin reentrant collapse feature. The succession above the truncation surface shows alternations of carbonate grain-dominated, siliciclastic-dominated, and carbonate debris-dominated middle-slope assemblages. The uppermost portion of WS consists of upper-slope in situ boundstones. Partial or patchy dolomite, apparently non-facies selective but sometimes fabric selective, is common in the lower half of WS, while the upper half of the section is dominantly limestone, with variable degrees of intermixed siliciclastics throughout. Physical walk-outs between WS, WNA, and WV measured sections were achieved.

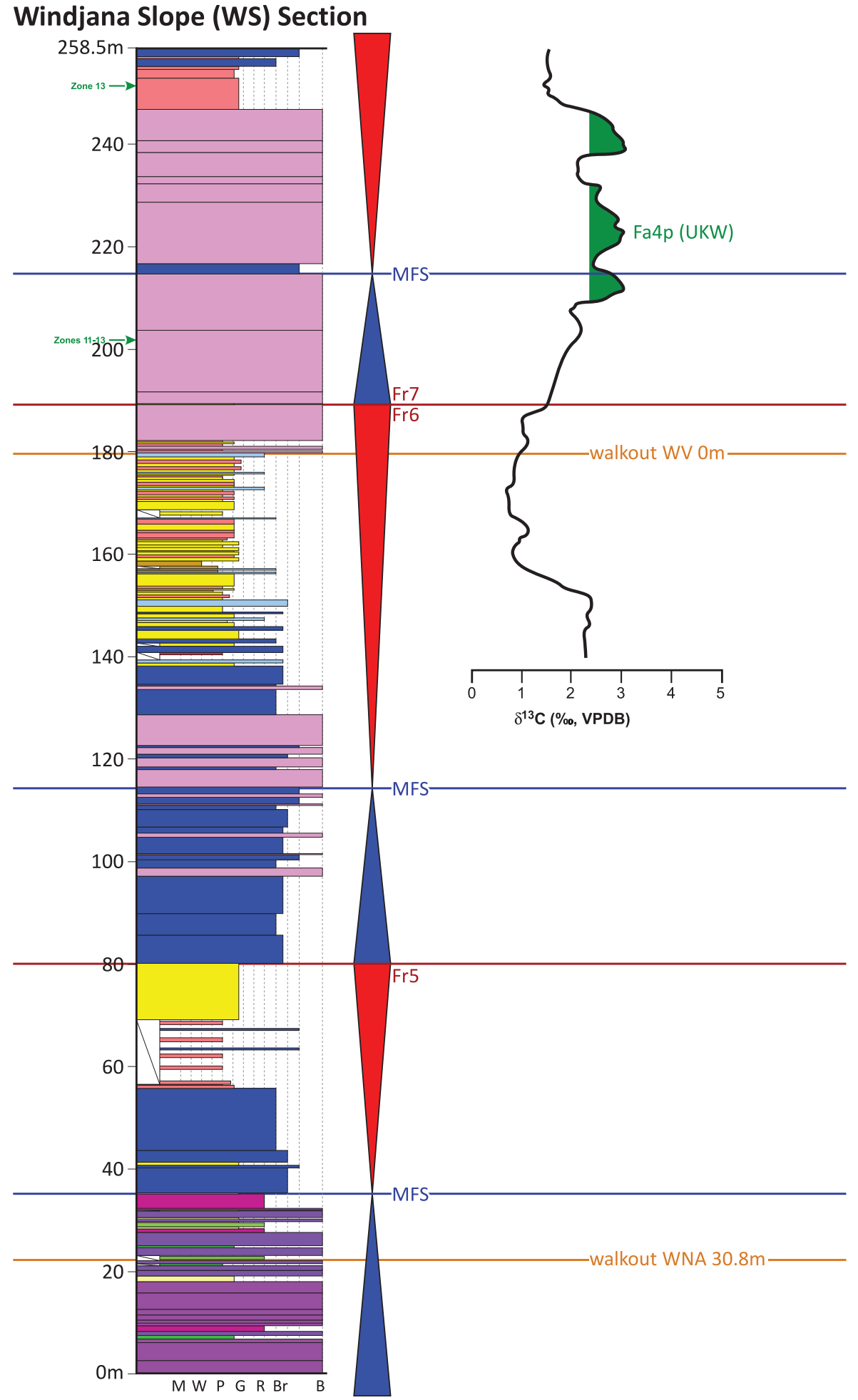




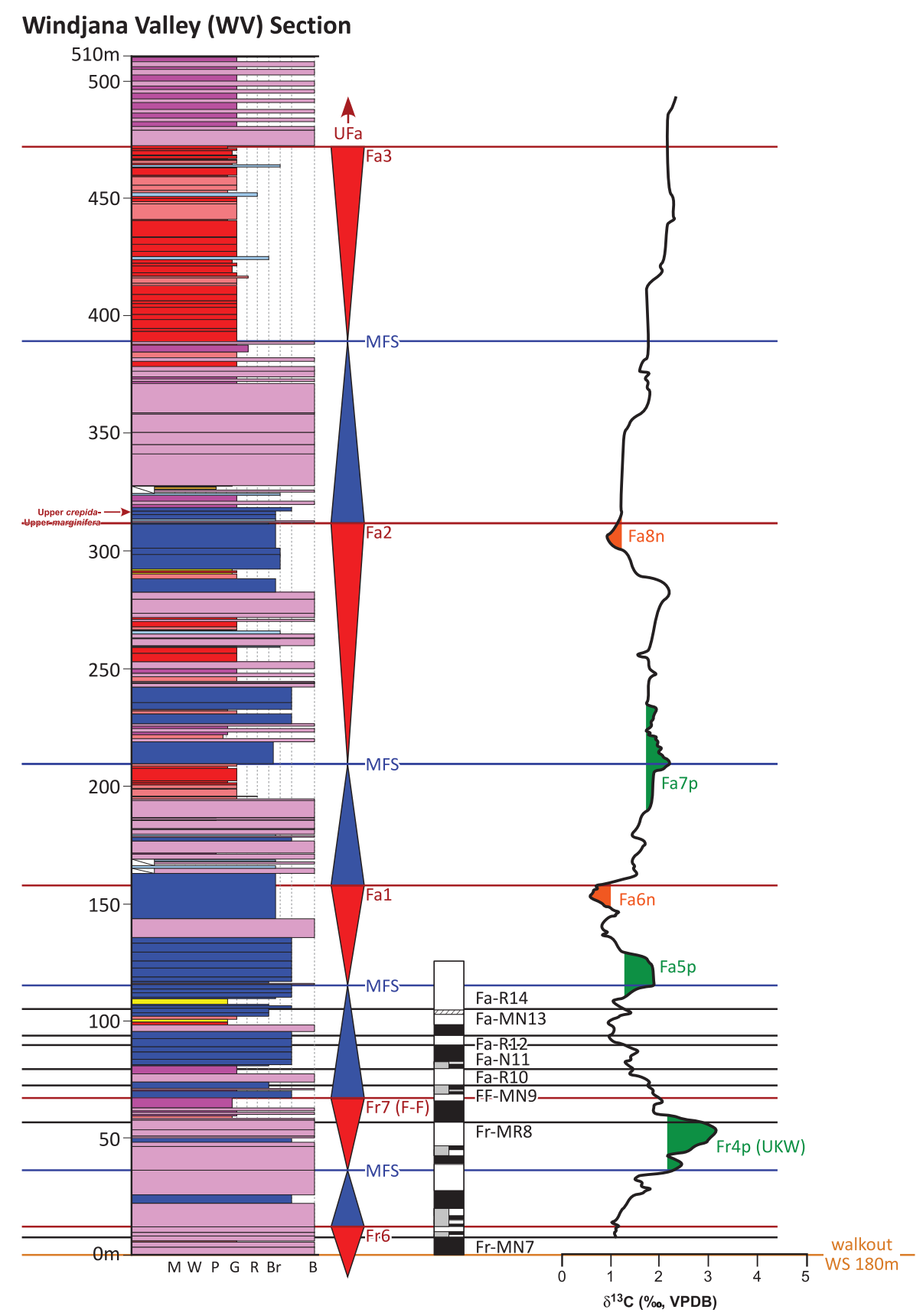

Appendix 5.-Windjana Valley (WV) measured section with correlation constraints. See Appendix 1 for legend and Figure 1 for location along the Lennard Shelf. WV is located in the Napier Ranges just northwest of Windjana Gorge $\left(17^{\circ} 23^{\prime} 44.53^{\prime \prime} \mathrm{S}, 124^{\circ} 56^{\prime} 49.61^{\prime \prime} \mathrm{E}\right.$ to $17^{\circ} 24^{\prime} 5.44^{\prime \prime} \mathrm{S}, 124^{\circ} 56^{\prime} 21.24^{\prime \prime} \mathrm{E}$; slightly further than the WS transect) and shares a similar paleogeographic setting as WS. WV is Upper Frasnian to Middle Famennian in age, based on recovered biostratigraphic control as well as correlations to key control sections. Facies exposed at WV consist of intervals of (1) graded, platform-derived grainstone-packstone, (2) margin-derived breccia-blocks, and (3) in situ microbial boundstone-encrusted grainstone, indicative of alternations between middle-slope allochthonous and upper-slope autochthonous environments. Depositional dips, corroborated by geopetals, range from 25 to $40^{\circ}$ after tilt correction. Stratigraphically upward, there are multiple alternations of middle- and upper-slope deposits. WV strata are dominantly limestone throughout, with variable degrees of intermixed siliciclastics. 
APPENDIX 6.-South Oscars (SO) measured section with correlation constraints. See Appendix 1 for legend and Figure 1 for location along the Lennard Shelf. SO is located in the southern Oscar Range (17 $54^{\prime} 53.14 " \mathrm{~S}, 125^{\circ} 17^{\prime} 59.13^{\prime \prime} \mathrm{E}$ to $\left.17^{\circ} 55^{\prime} 25.94^{\prime \prime S}, 125^{\circ} 17^{\prime} 22.05^{\prime \prime E}\right)$ and has a nearby parallel section for validation (SOB section; $17^{\circ} 55^{\prime} 16.58^{\prime \prime} \mathrm{S}$, $125^{\circ} 17^{\prime} 20.95^{\prime \prime} \mathrm{E}$ to $17^{\circ} 55^{\prime} 22.02^{\prime \prime} \mathrm{S}$, $\left.125^{\circ} 17^{\prime} 16.95^{\prime \prime E}\right)$. Paleogeographically, the Oscar Range was a topographic and structural high composed of basement rocks, outboard of the Lennard Shelf proper. It served as a nucleation point for carbonates to form a partially detached, carbonate-fringed island - the SO section is on the seaward side of the structure and is sheltered from siliciclastic input, thus representing the purest carbonate setting across the CBCP data set. The SO section extends from Lower Frasnian to Middle Famennian in age, based on robust biostratigraphic control. Facies exposed at SO consist of (1) graded, platformderived grainstone-packstone, (2) margin- and platform-derived bioclastic rudstone-floatstone, (3) margin-derived breccia-blocks, (4) a curious silty, wispylaminated micropeloidal packstonegrainstone facies, and (5) interbeds of in situ microbial boundstone-encrusted grainstone, all indicative of dominantly middle-slope environments with encroachments of the upper-middle-slope transition. Depositional dips, corroborated by geopetals, range from 20 to $30^{\circ}$ after tilt correction. Stratigraphically upward facies grade from those deposited in dominantly allochthonous middle-slope environments to a mixed detrital-in situ assemblage of the upper-middle-slope transition. Middle-slope assemblages and deposit proportions (i.e., grain- vs. debrisdominated) vary throughout the stratigraphy. SO strata are dominantly limestone throughout, with very little dolomite and no macroscopically observed siliciclastics.

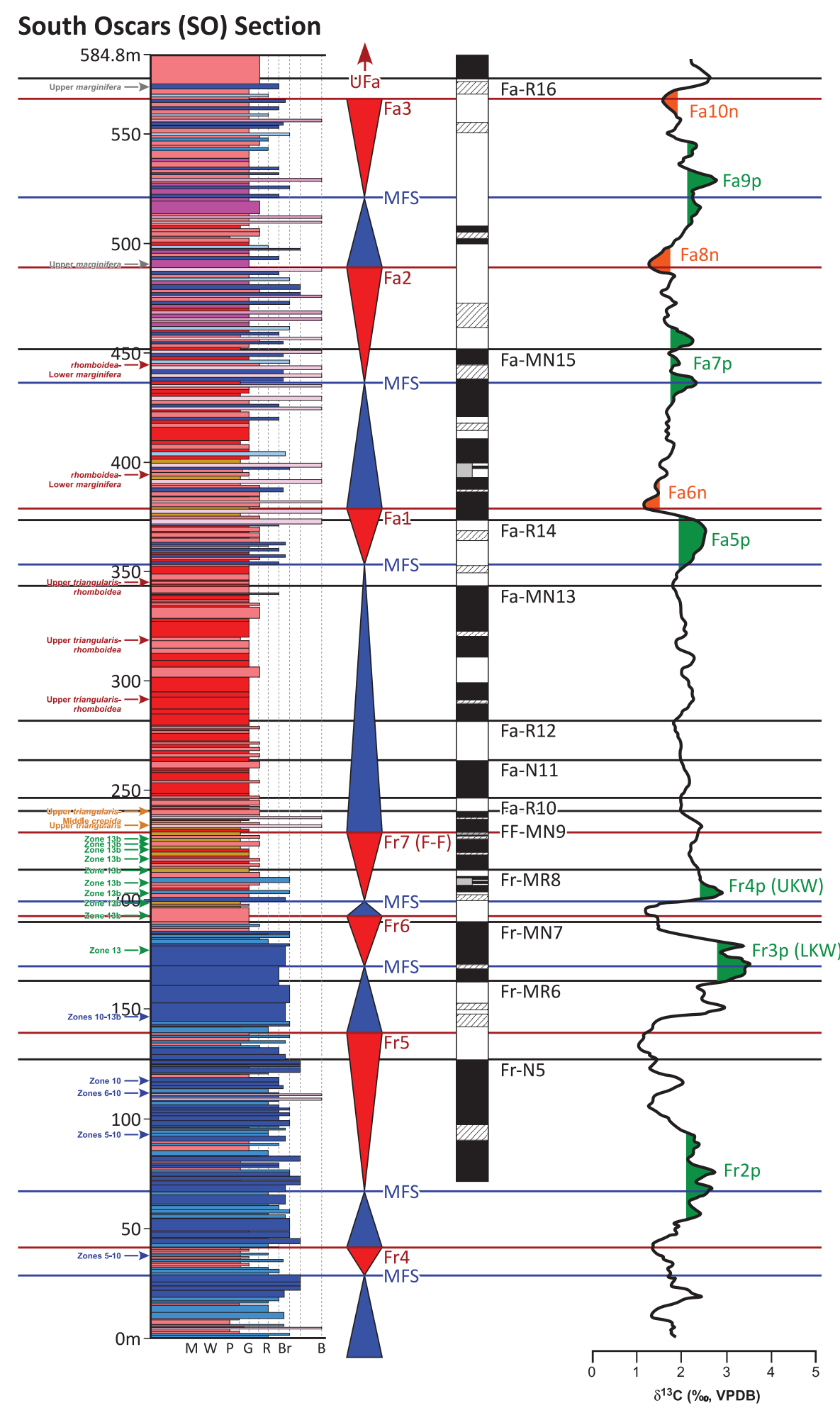




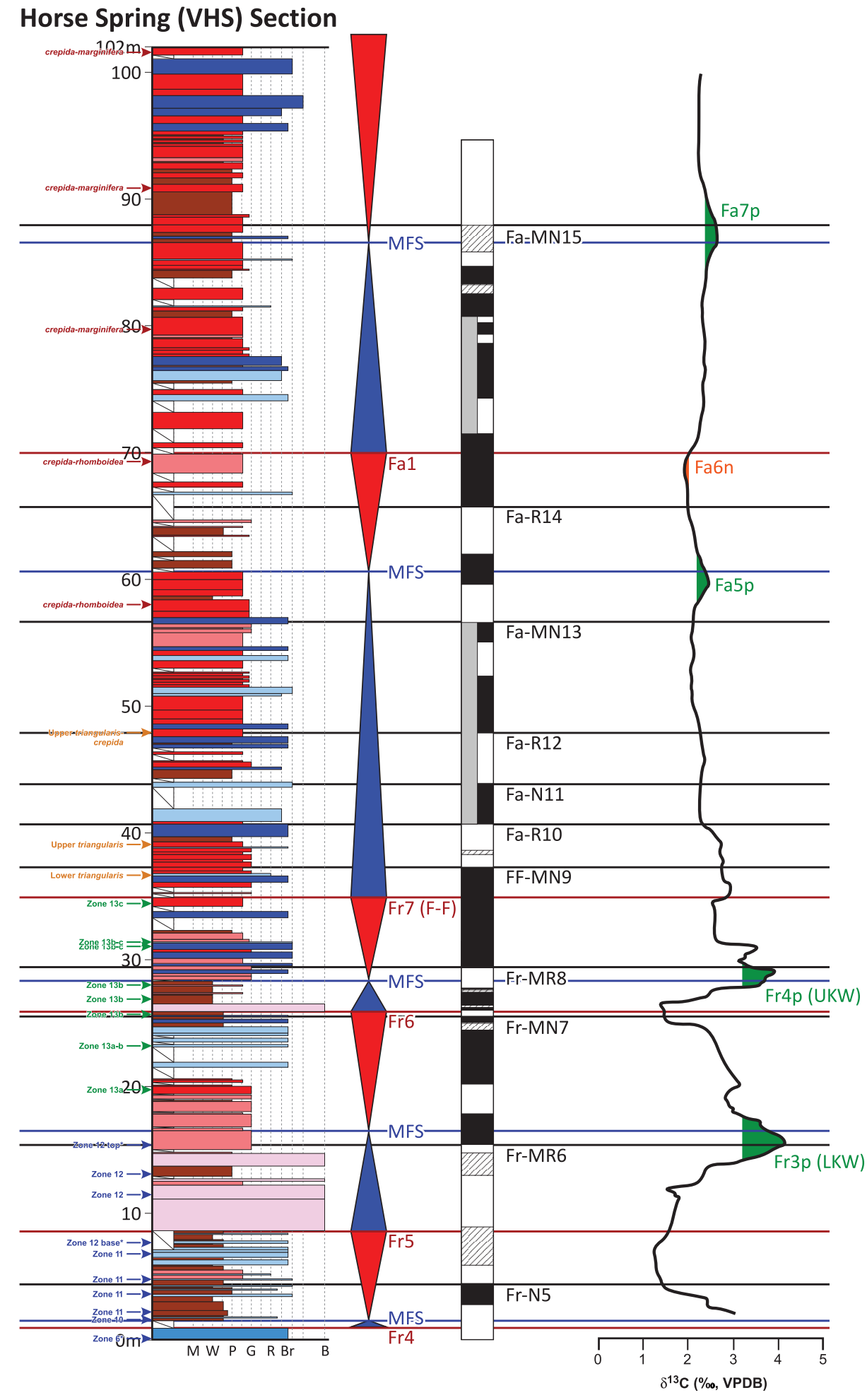

ApPendix 7.--Horse Spring (VHS-Virgin Hills South) measured section with correlation constraints. See Appendix 1 for legend and Figure 1 for location along the Lennard Shelf. VHS is located in the Horse Spring Range (18 $11^{\prime} 45.97^{\prime \prime} \mathrm{S}$, $126^{\circ} 1^{\prime} 55.99^{\prime \prime} \mathrm{E}$ to $18^{\circ} 11^{\prime} 38.63^{\prime \prime S}$, $\left.126^{\circ} 1^{\prime} 49.59^{\prime \prime E}\right)$. Paleogeographically, the Horse Spring Range tracks a segment along a large ( $>50 \mathrm{~km}$ across) embayment within the Lennard Shelf; thus, local dip directions are west-northwesterly (as opposed to regional southwest dips toward the Fitzroy Trough). VHS is Lower Frasnian to Middle Famennian in age, based on robust biostratigraphic control. Facies exposed at VHS consist of (1) graded, platform-derived grainstonepackstone, (2) mottled to wispy silty skeletal-peloidal packstones-wackestones-mudstones, (3) lesser margin-derived breccia-blocks and intraclasticbioclastic rudstones-floatstones, and (4) rare in situ microbial boundstone, all indicative of lower-slope environments. Depositional dips, corroborated by geopetals, range from 10 to $15^{\circ}$ after tilt correction. Vertically, facies are quite interbedded, with no striking patterns; however, intervals are observed with greater proportions of margin-derived debris. VHS strata are dominantly limestone throughout, with very little dolomite and no macroscopically observed siliciclastics except for silt-sized fractions intermixed into muddier deposits. 
Appendix 8.-Casey Falls (CL) measured section with correlation constraints. See Appendix 1 for legend and Figure 1 for location along the Lennard Shelf. CL is located in the southern Lawford Range $\left(18^{\circ} 44^{\prime} 0.03^{\prime \prime} \mathrm{S}, 126^{\circ} 5^{\prime} 8.96^{\prime \prime} \mathrm{E}\right.$ to $\left.18^{\circ} 44^{\prime} 9.39^{\prime \prime} \mathrm{S}, 126^{\circ} 5^{\prime} 41.23^{\prime \prime E}\right)$ and has a parallel section for validation (CLB section; $18^{\circ} 44^{\prime} 3.93^{\prime \prime} \mathrm{S}, 126^{\circ} 5^{\prime} 34.88^{\prime \prime} \mathrm{E}$ to $\left.18^{\circ} 44^{\prime} 7.31^{\prime \prime S}, 126^{\circ} 5^{\prime} 40.43 " \mathrm{H}\right)$. Paleogeographically, the Lawford Range and greater Bugle Gap area display exhumed Lower Frasnian paleo-reef topography with extremely complex spine and pinnacle configurations generated from backstepping - the CL section records subsequent progradation and downlap over this relict topography, with local dip directions to the south-southeast contrasting with regional southwesterly dips. $\mathrm{CL}$ is Upper Frasnian to Middle Famennian in age, based on robust biostratigraphic control. Facies exposed at CL consist of (1) silty skeletal-peloid packstone-wackestone-mudstone with minor microbial boundstone interbeds and platform-derived grainstones, representing a lower-slope to basinal environment; and (2) steeply-dipping, bedded microbial boundstone and encrusted grainstone, indicative of upper-slope settings. Margin-derived breccias and blocks are rare to absent throughout the succession. Depositional dips, corroborated by geopetals and after tilt correction, range from 10 to $20^{\circ}$ in siltier deposits (although believed to be enhanced by differential compaction over underlying margins) and from 25 to $40^{\circ}$ in boundstone deposits. Stratigraphically upward, facies grade and interfinger gradually from silt-dominated lower-slope basinal deposits to upperslope boundstones, resulting in an odd succession with seemingly no intermediate middle-slope setting of debris, grainstone, and rudstone (see Playton and Kerans 2015b). CL strata are dominantly limestone throughout, with no dolomite or macroscopically observed siliciclastics except for silt-sized fractions intermixed into muddier deposits. A key marker bed (shrub-like Frutexites microbialite; Playford et al. 2009) that is unique and distinctive in the area is observed in the basal portion of the CL section and marks the top of the MR1 Winkie core, providing a tie point between the two transects.

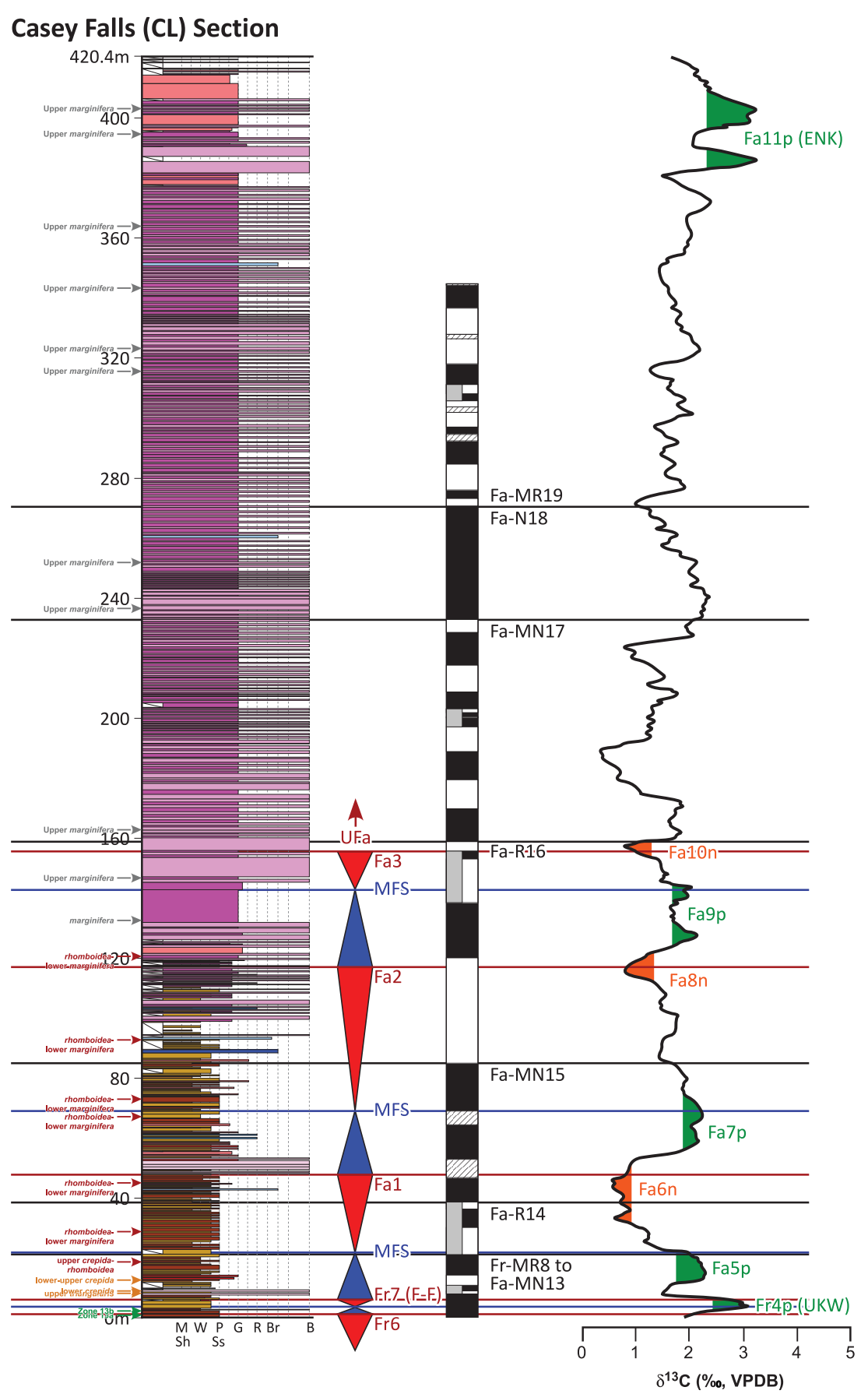




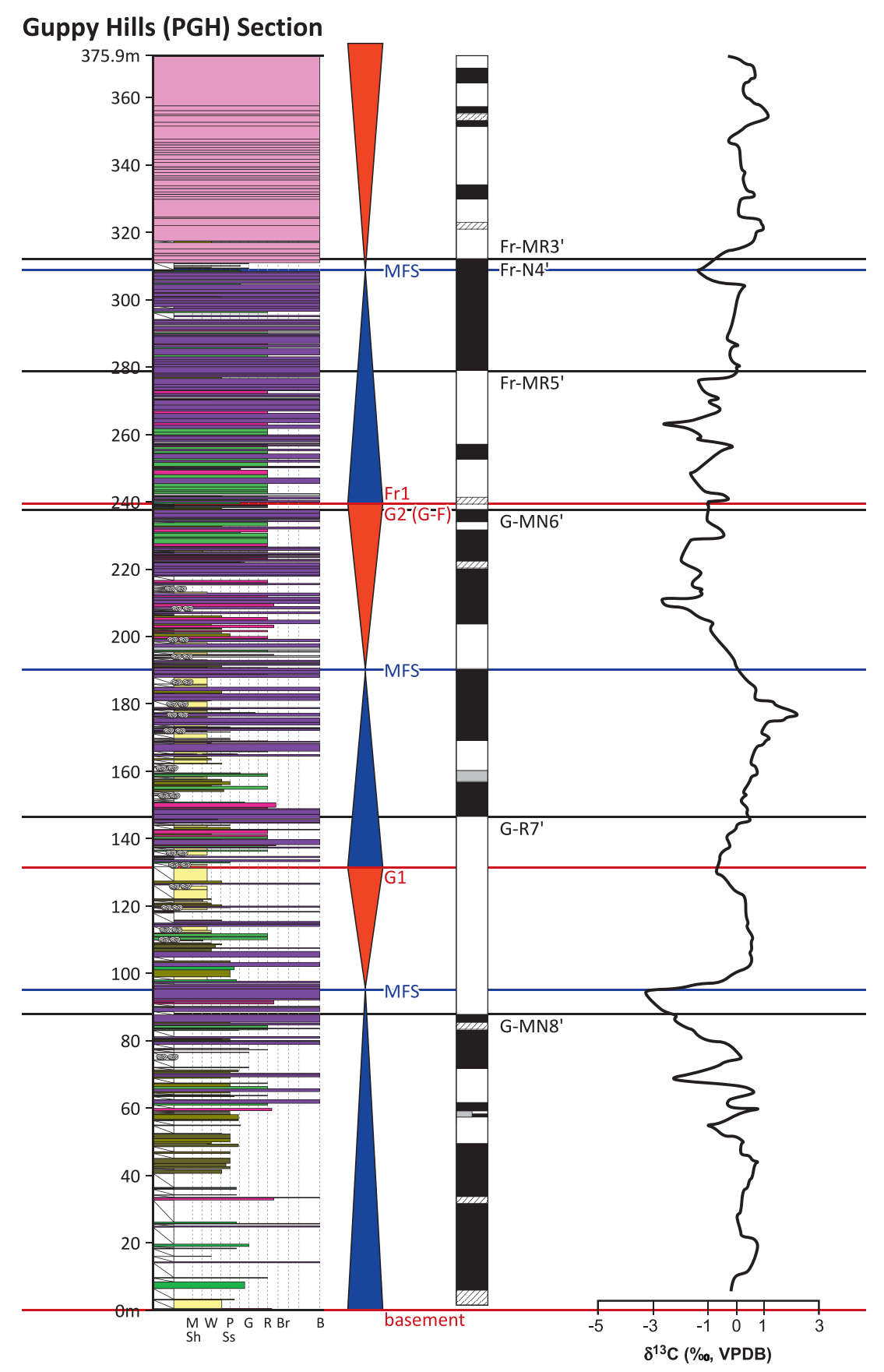

ApPendix 9.-Guppy Hills (PGH-Pillara Guppy Hills) measured section with correlation constraints. See Appendix 1 for legend and Figure 1 for location along the Lennard Shelf. PGH extends across the western end of Guppy Hills, south of the Hull Range (18 $17^{\prime} 52.90^{\prime \prime S}, 126^{\circ} 9^{\prime} 0.76^{\prime \prime} \mathrm{E}$ to $18^{\circ} 17^{\prime} 28.23$ "S, $126^{\circ} 9^{\prime} 19.85^{\prime \prime} \mathrm{E}$ ) and has a parallel section for validation (GHB section; $18^{\circ} 18^{\prime} 0.30^{\prime \prime} \mathrm{S}, 126^{\circ} 9^{\prime} 15.56^{\prime \prime} \mathrm{E}$ to $\left.18^{\circ} 17^{\prime} 55.31^{\prime \prime S}, 126^{\circ} 9^{\prime} 18.16^{\prime \prime E}\right)$. Paleogeographically, the Hull Range and Guppy Hills areas show complex paleo-topography along the Lennard Shelf due to basement-cored structures that produced elongate and irregular reentrant-promontory configurations - thus, slope portions of the PGH section dip northerly, in contrast to the regional southwest dips into the Fitzroy Trough. Siliciclastic sources were abundant and close by. PGH is interpreted to be Givetian to Lower Frasnian in age based on coarse coral successions but is very poorly constrained biostratigraphically (e.g., George et al. [2009] interpret it to be all Lower Frasnian based on Hull Range extrapolations). Facies exposed at PGH consist of (1) cycles of skeletal-peloid grainstonespackstones, bioclastic rudstones-floatstones, peloidal packstones-wackestonesmudstones, and siliciclastics, representing inner platform-top settings; (2) cyclic skeletal-peloid grainstones-packstones, bioclastic rudstones-floatstones, and in situ, bedded stromatoporoid framestones, indicative of outer platform-top to reef-flat settings; and (3) dipping, bedded stromatactoid microbial boundstone, diagnostic of encrusted slope environments. Depositional dips in slope strata, corroborated by geopetals, range from 10 to $15^{\circ}$ after tilt correction. Stratigraphically upward, facies grade from inner platform-top to outer platform-top to reef-flat settings, followed by an abrupt transition into slope deposits across an interpreted backstep surface. At the backstep surface, a few meters of graded grain-dominated deposits are present, interpreted to be sediment gravity flows equivalent to a landward margin. Inner platform-top carbonate facies are commonly dolomitic, and outer platform to reef-flat and slope boundstone carbonate facies are dominantly limestone, with variable degrees of intermixed fine siliciclastics. 
APPENDIX 10.--Henwood West (NHWNorth Henwood West) measured section with correlation constraints. See Appendix 1 for legend and Figure 1 for location along the Lennard Shelf. NHW is located south of the Horseshoe Range $\left(18^{\circ} 14^{\prime} 6.29^{\prime \prime} \mathrm{S}, 126^{\circ} 10^{\prime} 15.94^{\prime \prime} \mathrm{E}\right.$ to $\left.18^{\circ} 13^{\prime} 57.99^{\prime \prime} \mathrm{S}, 126^{\circ} 10^{\prime} 20.81 " E\right)$. Paleogeographically, the Henwood West area is in the same setting as that described for Guppy Hills (PGH), but the NHW section is interpreted to be Upper Frasnian to Lower Famennian in age based on reef assemblage observations. The $\mathrm{F}-\mathrm{F}$ boundary is well-exposed, with clear Famennian reef flat facies overlying Frasnian reef front facies, but the NHW section is not a critical transect for the CBCP. Facies exposed at NHW consist of (1) boundstones ranging from stromatoporoid framestones to microbial boundstones, representing reef-core settings; and (2) cyclic grainstone-packstone ranging in composition from nonskeletal to skeletal, oncolitic rudstone-floatstone, in situ Lithiotid (razor clam) floatstone, and conglomeratic to fine-grained siliciclastics, with a few occurrences of columnar stromatolitic microbial boundstone, all indicative of outer platform-top and platform-crest to reef-flat environments. In reef-core intervals, encrusting stromatoporoids display horizontally accreting fabrics reflecting growth upon subvertical surfaces. Stratigraphically upward, facies grade from reef-core (with decreasing stromatoporoids upward) to reef-flat to outer-platform and platformcrest settings, signifying progradation. Reef-core facies are dominantly limestone with some patchy intermixed siliciclastics, and the shallower settings are chiefly a mixed limestone-siliciclastic lithology.

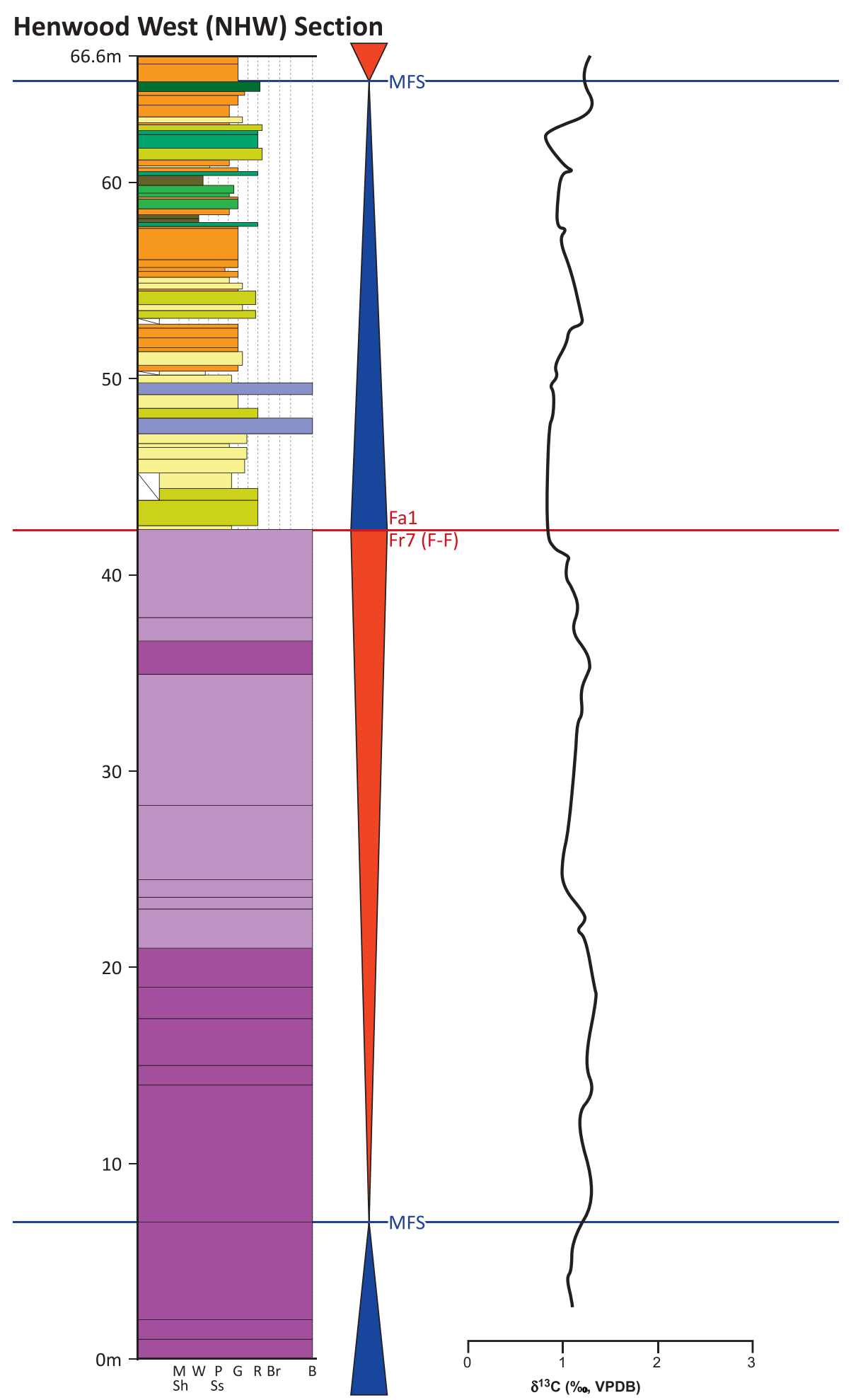




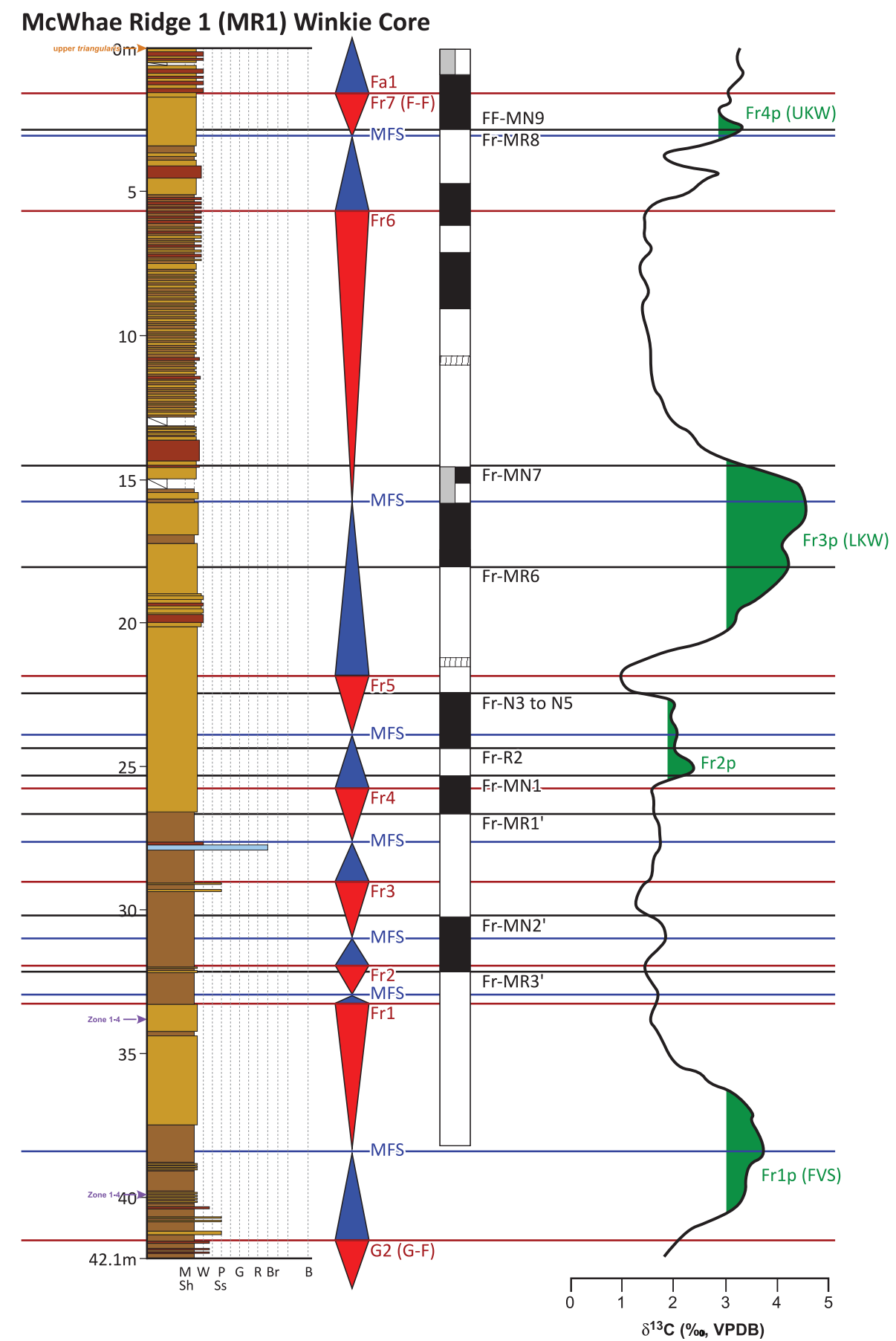

ApPendix 11.-McWhae Ridge (MR1) Winkie core with correlation constraints. See Appendix 1 for legend and Figure 1 for location along the Lennard Shelf. MR1 was drilled on the flank of McWhae Ridge in the Lawford Range

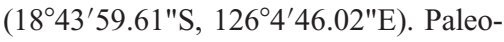
geographically, the McWhae Ridge area is in the same overall setting as that described for Casey Falls (CL); however, McWhae Ridge itself is a Lower Frasnian drowned reef spine, and the MR1 core samples younger, sidelapping strata along its flank. MR1 is Upper Givetian to Lower Famennian in age based on moderately well-constrained biostratigraphy. Facies of MR1 consist of silty skeletal-peloid mudstone-wackestone with minor packstone and rare intraclastic rudstone, representative of toe of slope or basinal environments. Depositional dips are 10 to $15^{\circ}$ but are likely steepened by compaction against underlying paleo-topography. There are no readily identifiable vertical patterns or changes in setting throughout the core, and the dominant lithology is limestone, with the exception of scattered occurrences of intermixed siliciclastic silt. A key marker bed (shrub-like Frutexites microbialite; Playford et al. 2009) that is unique and distinctive in the area marks the top of MR1 and can be observed in the basal portion of the CL section, providing a tie point between the two transects. 
ApPendix 12.-Wade Knoll (WK1)

Winkie core with correlation constraints.

See Appendix 1 for legend and Figure 1

for location along the Lennard Shelf.

WK1 was drilled in Paddy's Valley

between the Emmanuel and Laidlaw

Ranges (18³9'25.04"S, $\left.126^{\circ} 0^{\prime} 5.19^{\prime \prime} \mathrm{E}\right)$.

Paleogeographically, Paddy's Valley is in the same overall setting as that described for Casey Falls (CL); however, it is in the center of an intraplatform mini-basin between two elongate reefal platforms. WK1 has no biostratigraphic control but spuds on a Lower Frasnian marker bedit is unknown what age the core base is, and it is not a critical transect in the CBCP data set. Facies of WK1 consist of silty skeletal-peloid mudstone-wackestone-packstone with rare intraclastic rudstone, representative of toe of slope or basinal environments. Depositional dips are $3^{\circ}$ or less after tilt correction. There are no readily identifiable vertical patterns or changes in setting throughout the core, and the dominant lithology is limestone.
Wade Knoll 1 (WK1) Winkie Core

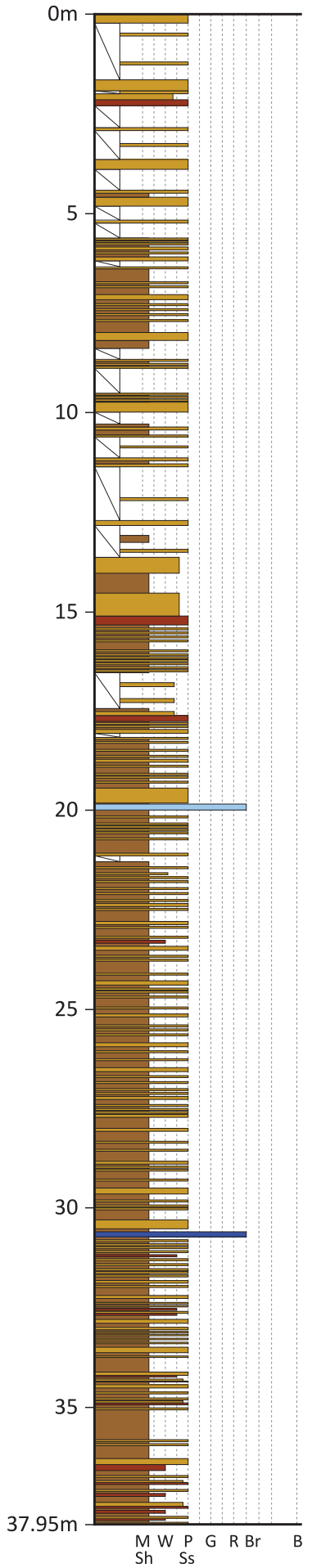


Horseshoe Range (UD2) Core

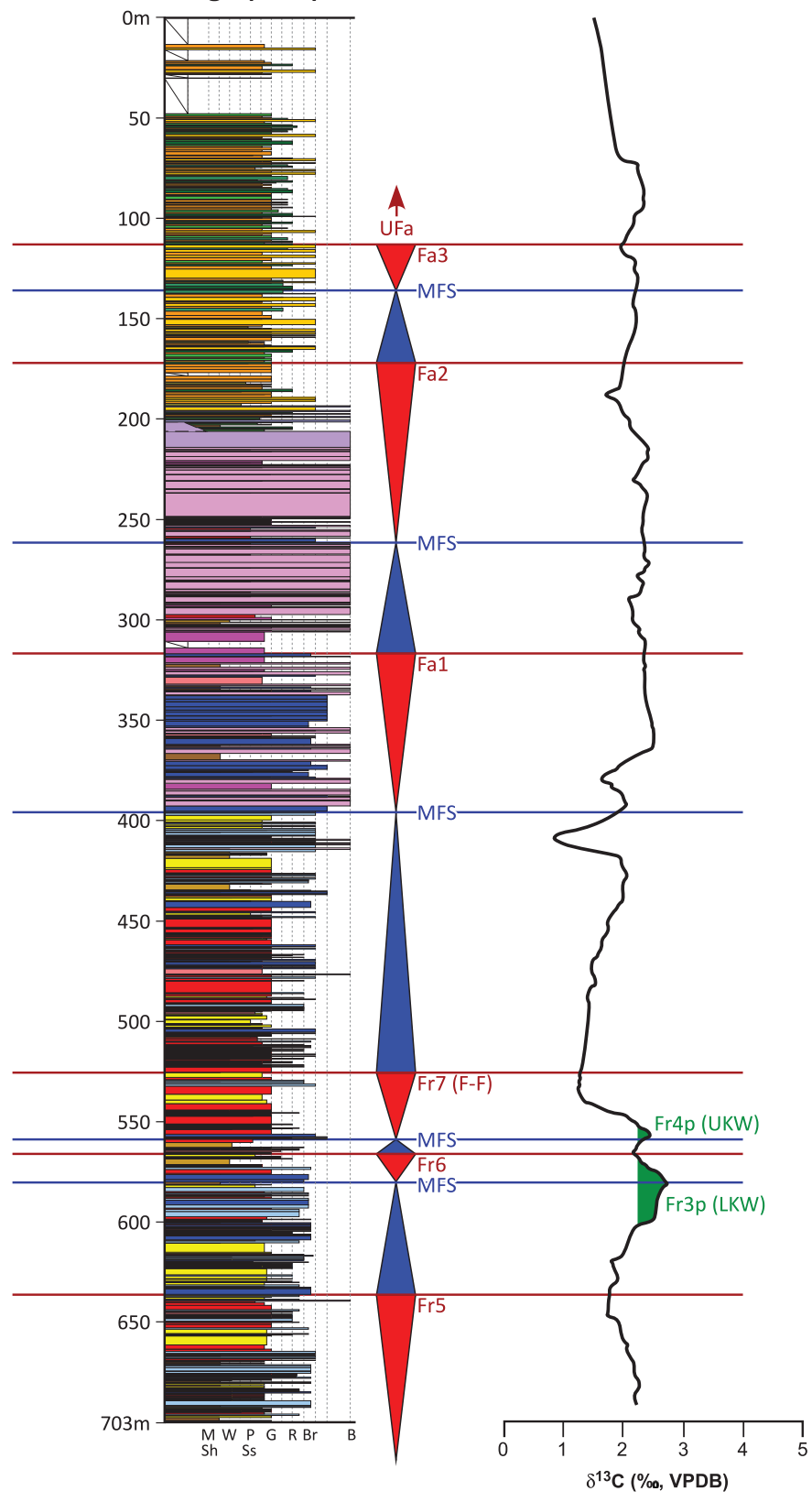

ApPendix 13.--Horseshoe Range (UD2) subsurface core with correlation constraints. See Appendix 1 for legend and Figure 1 for location along the Lennard Shelf. UD2 was drilled in the Horseshoe Range (approximately $18^{\circ} 13^{\prime} 19.80^{\prime \prime} \mathrm{S}$, $\left.126^{\circ} 11^{\prime} 53.94^{\prime \prime E}\right)$. Paleogeographically, the Horseshoe Range is in the same overall setting as that described for Guppy Hills (PGH); however, it is on the inboard side of complex basement-cored topography (i.e., is directly attached to the hinterland) and reflects a fairly narrow $(\sim 5 \mathrm{~km})$ shelf with a prevalent siliciclastic source. UD2 has no biostratigraphic control but can be placed within the stratigraphic framework with moderate confidence as a result of its isotopic profile and extensive facies record-this interpretation defines UD2 as Middle Frasnian to Middle Famennian in age. The facies in UD2 include all slope assemblages described previously (siltdominated, grain-dominated, siliciclasticdominated, debris-dominated, boundstone-dominated), reefal margin microbial boundstones, and outer platform-top and platform-crest assemblages similar to those described for NHW but with the addition of teepee pisolite and muddier shoreline facies and absence of fine to conglomeratic siliciclastics. The vertical succession throughout all of UD2 is a classic upward prograding or shallowing sequence of facies, grading from middle slope to upper slope to reef core to reef flat to platform-top. The platform-top succession itself displays trends in facies proportions and cycle-bed thickness. The dominant lithology throughout UD2 is mixed limestone-siliciclastic; however, dolomitic zones with variable degrees of intermixed siliciclastics are present and are likely related to Mississippi Valley Type mineralization. 
Appendix 14.--Horse Spring (HD14) subsurface core with correlation constraints. See Appendix 1 for legend and Figure 1 for location along the Lennard Shelf. HD14 was drilled in the Horse Spring Range (approximately $\left.18^{\circ} 13^{\prime} 51.40 " \mathrm{~S}, 126^{\circ} 3^{\prime} 20.10^{\prime \prime E}\right)$. The paleogeographic setting is the same as for the VHS section. HD14 has no biostratigraphic control, but our best estimate is Upper Givetian to Lower Frasnian age. Facies and the vertical succession of HD14 are similar to those described for $\mathrm{PGH}$, but with a greater proportion of inner platform-top assemblages. A pronounced backstep with encrusted slope overlying outer platform is also observed at HD14, but we interpret this to be a younger backstepping event than that occurring at PGH. The dominant lithology throughout HD14 is dolomite, with scattered intermixing of siliciclastics, with the exception of the uppermost interval above the backstep surface, which is dominantly limestone.

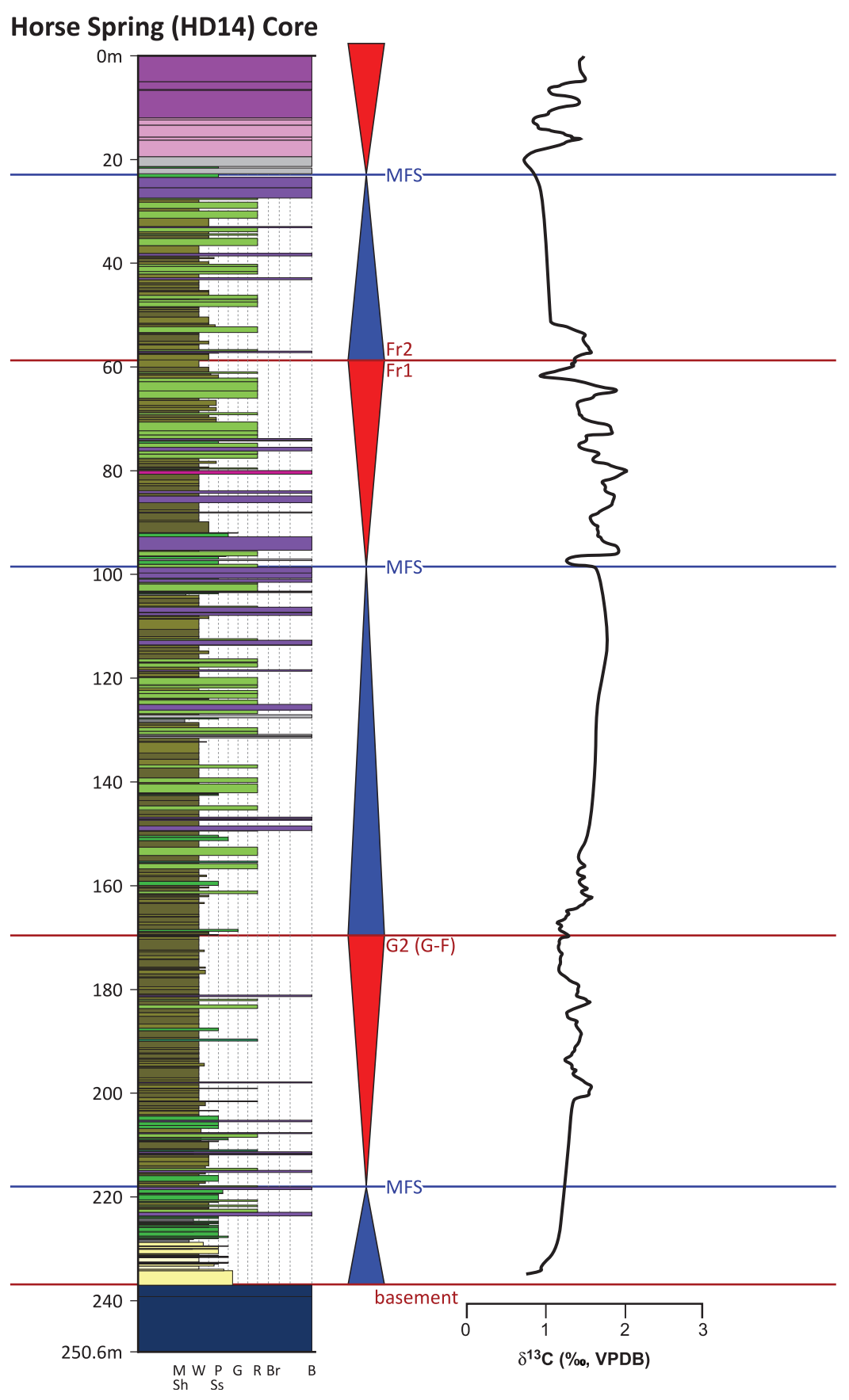

